\title{
88073075
}

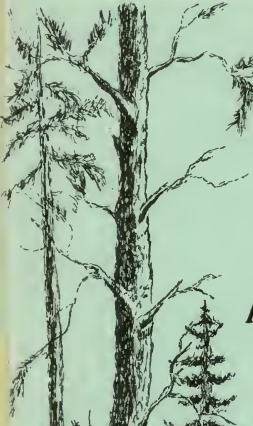

Annual Progress Report

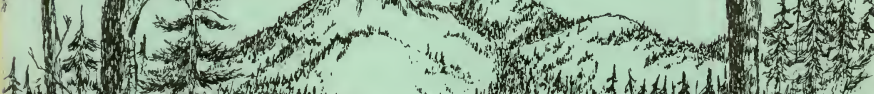

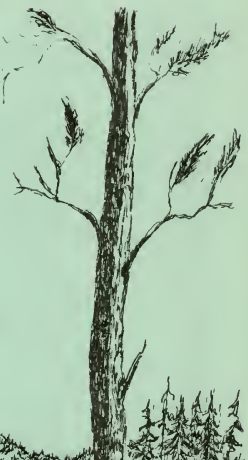

1. 1 S

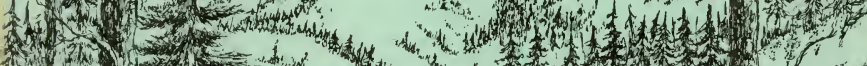

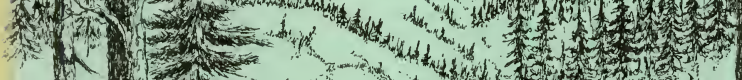

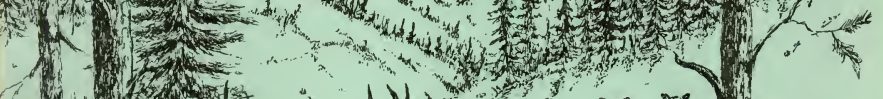

is fol

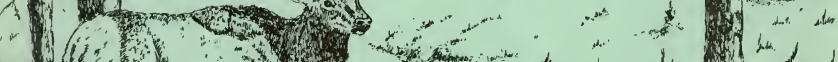

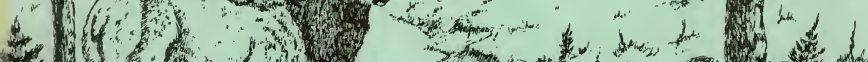

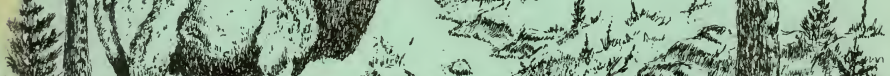

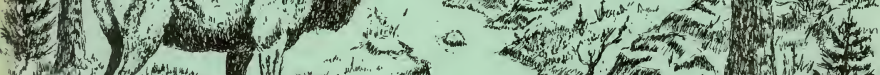

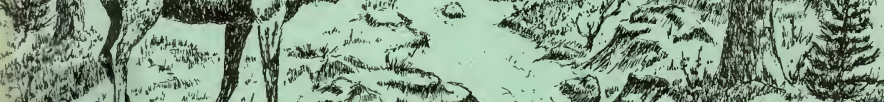

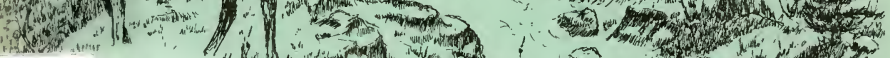

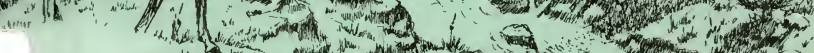

QL 1. (1) 3 (3) if 
MONTANA

COOPERATIVE ELK-LOGGING STUDY

Progress Report for the Period

January 1-December 31, 1979

COOPERATING AGENCIES

Region I, U.S. Forest Service Intermountain Forest and Range Experiment Station Bureau of Land Management Montana Department of Fish, Wildlife, and Parks

School of Forestry, University of Montana
STEERTNG COMMTTEE

Edwand Schneegas, Chaiman

Thadd Harrington

Don McIntosh

Eugene 0. Allen

W. Leslie Pengelly

Submitted by Research Committee

L. Jack Lyon, INT, USFS, Chairman

Terry N. Lonner, F, W and P

Jack Jones, B L M

C. Les Marcum, $U$ of $M$

John Weigand, F, W and $\mathrm{P}$

Darrell Sall, B L M

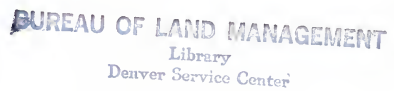


The mailing list for the Montana Cooperative Elk-logging Annual Report has become long and unwieldy:me and is being discarded.

If you wish to continue to receive these reports, please not ify:

L. Jack Lyon

Forestry Sciences Laboratory

U.S.Forest Service

Drawer G

Missoula, Montana 59806 


\section{i i i}

\section{TABLE OF CONTENTS}

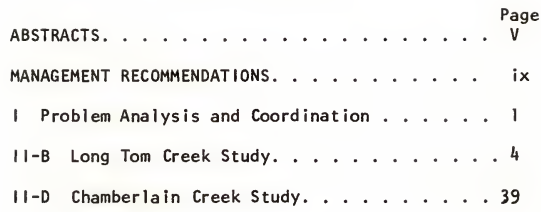


MONTANA COOPERATIVE ELK-LOGGING STUDY

January - December 1979

ABSTRACTS

JOB I

PROBLEM ANALYSIS AND COORDINATION

During the year, steering and research committees met twice to plan, review and coordinate project activities. A total of 13 presentations were made by research committee personnel to various groups, organizations and workshops. The slide series compiled last year was produced as a slide/tape and distributed throughout the Forest Service. Sixtynine citations were added to the computerized bibliography and all duplicates were el iminated. The tape now contains 449 entries. 
JOB II-B

LONG TOM CREEK STUDY

\section{Abstract}

The 1979 field season was the efghth year of the study and the second postlogging year. Pre-logging years were 1972-1974 and logging years included 1975-1977. The single factor thus far measured to influence overal1 summerearly fall elk use of the study area was precipitation from October-August immediately preceeding and during a field season. When precipitation was high elk use was low and vice versa. Although yearly summer-early fall elk use has varied, the distributional pattern of how elk used the area remained fairly consistent. However, some shifts of elk use away from the sale area did occur during and after the logging activity and some of these shifts were recorded up to about two miles away. Over 2000 relocations of 36 radio-equipped elk have been made since the spring of 1973, and findings have shown individual elk to have a very strong affinity to use the same summer and winter areas year to year. Seasonal home range sizes of these elk have varied substantially, ranging from near 0 to 160 square miles. A11 2000 relocations combined covered an area of about 685 square miles. Around the clock bihourly relocations of several radio-collared elk have been made during 14 ground triangulation sessions since 1977 and have shown the elk to be continuously active and moving. Movement activity was highest during morning hours (0400-0800) and least during midday hours (0800-1600). An evaluation of forage characteristics of various logged and unlogged cover types in the study area was completed as a Montana State University graduate research project. Results of this study showed nutritional quality of forage to be at a seasonal high during early summer on a11 sites sampled. Overa11, through summer, forbs demonstrated higher quality than grasses and sedges. Both uncut and cut-through dry parks and wet meadows represented the most productive and species diverse types available to elk during early summer. A high nutritive value of forage species on phenologically delayed sites was reflected in comparatively high cell-soluble content values for forage species on both forested and wet meadow sites. Opening up the forest canopy by clearcutting increased forage production and species diversity, but nutritional quality of the forage was lower compared to that of most uncut types. 
ABSTRACT

JOB II-D

\section{CHAMBERLAIN CREEK STUDY}

Objectives of this study are to describe elk distribution and elk use of several available environmental factors before, during, and after logging. The contract road into the west side of the core study area was completed during 1979, and a spur road was extended into the northeast corner of the area. No logging was done in the core study area during 1979. The Chamberlain Creek Sale was let in November 1979. Road building will continue during 1980 , and logging will be initiated on Burlington Northern cutting units. Habitat selection, movements and distribution of elk during 1979 are reported. These results complement and reinforce our conclusion that, under relatively undisturbed conditions, the primary factors influencing elk habitat use and distribution patterns are a combination of weather plus vegetative composition, structure and phenology. There continues to be a high negative correlation $(r=-0.99)$ between yearly precipitation and total elk use of the core study area, where logging is planned. Road closures initiated in the Blackfoot Special Management Area, which includes much of the study area, during 1974 have contributed to increased hunting opportunity and quality in recent years. Opportunities for either sex elk hunting tend to be increasing here, while they tend to be decreasing in nearby areas where roads remain open to vehicular access. 
Certain findings appear to be firmly based and worthy of consideration. In order that management can benefit from the study effort prior to the final report, the research committee has been directed by the steering committee to formulate tentative management recommendations or guidelines based on findings-to-date.

It is not intended that these recommendations be broadly applied throughout the forests of Montana. Likewise, it is not intended that they be considered the "last word" or an attempt to dictate management practices to public agencies or private corporations. It is intended that they be considered a portion of the wildlffe input that should be evaluated, along with many other values and inputs, in the planning of all timber sales and road construction projects. If a recommendation fits the situation, in an identified elk-use area, its implementation will help minimize any detrimental impact on the elk in the area. The recommendations merely represent an attempt by the study team to place significant findings in the hands of management as the research study progresses.

The following recommendations, although based on the best information presently avallable, are considered tentative and subject to change; the hazards of extrapolation must be recognized. They may not apply to certain local situations and 11teral application should not be substituted for detailed, joint discussions and on-the-ground inspections by timber and wildiffe managers and other resource specialists.

\section{SECURITY AREA RECOMMENDATION}

\section{Research Finding:}

During active road building and logging, elk have responded by moving to surrounding ridgelines and further. The distance moved apparently depends on a variety of factors including size of the drainage area encompassed by logging, intensity and season of logging activities, and disturbance on the ridgelines.

Displacement of elk, which is considered temporary, has been detected as far as four miles from the area of summer logging activity. In one study, herd displacement was to an adjacent third order drainage and then beyond that drainage when the ridgeline was disturbed. In another investigation, displacement was down a ridgeline for two miles through undisturbed timber and over a point. In both cases, topographic features provided a line-of-sight barrier between elk and the logging activity. 
viil

Recommendation: Planning for timber sales in elk sumer range should include provision of a security area immediately adjacent to the disturbed area during the active logging and/or road building period. It is also suggested that disturbances with heavy equipment on elk summer range be completed in the shortest possible time and, if possible, during periods of the year when elk are not present.

Discussion: Security for elk is still an undefined concept, but it appears that an area adequate to reduce long distance displacement of animals by timber sale activities should satisfy the following minimum criteria:

-- it must be adjacent to and easily reached by elk dispersing from the disturbed area, and the intervening ridgeline must be protected from all mechanical activities.

-- it should contain a fairly large acreage of forest cover at the head of a drainage. The particular acreage required will depend on cover quality, but the areas available to elk in one study were about 5,000 acres, and this size also approximated the average summer range (June-August) used by several radio instrumented animals in another study.

Application of the security area concept on the ground must be based on individual situations as they exist. There is no way to specify an exact acreage required for all elk everywhere.

Several avallable security areas are considered far superior to a single area, and where consecutive timber sales progress from one drainage to the next, it is suggested that activity be confined to a single drainage at a time with completed sales being converted to security areas as quickly as possible. While the data for predicting duration of disturbance effect (i.e. how long before the elk return to a logged area) is still incomplete, the initial indications are that total time of disturbance is more important than the severity of disturbance. Intensive activity in a single season is far less detrimental than a low level of activity over several seasons.

\section{HABITAT TYPE-MOIST SITE RECOMMENDATION}

\section{Research Finding:}

Within the various study areas, findings-to-date indicate that during the summer months (June-September) elk prefer those sites at the head of drainages bordering streams or marshy meadows, or occupying moist swales or benches. All of these sites are characterized by their close proximity to areas where water is present, on or near the surface, for all or part of the summer period. Both east and west of the Continental Divide these sites are usually found within the Abies lasiocarpa habitat type series. East of the Continental Divide, the dominant vegetative components of these sites are Subalpine fir, Whitebark pine, spruce, or combinations thereof. These sites are usually found within the Abies lasiocarpal Calamagrostis canadensis, Abies lasiocarpa (pinus albicaulis)/Vaccinium 
scoparium, Abies lasiocarpa/Vaccinium scoparium (Thalictrum occidentale phase), and Abies lasiocarpa/Luzula hitchoockii habitat types as described by Pfister, et al. (1975). In western Montana these moist sites are generally found within the more hydric parts of the Abies lasiocarpal Luzula hitchcockii (menziesia phase), Abies lasiocarpa/Clintonia uniflora, Abies lasiocarpa/Menziesia fermginea, and the Abies lasiocarpa/Galium triflorum habitat types described by Pfister, et al. (1975).

Recommendation: Two general types of summer range situations exist in Montana. The first type occurs where moist sites are found in close proximity to each other, and in combination with other habitat components they comprise a rather large area, which is heavily used by elk. Another type of situation exists, where moist sites are not in close proximity with one another, but evenly distributed over the summer range. While this latter situation may support a large number of elk in total, each moist area may be used by relatively fewer animals. These two situations are not mutually exclusive, so both types can occur on portions of the same summer range. Where the first situation exists, an area large enough to maintain the overall integrity of the habitat components to be managed should be determined by an on-the-ground inspection by land and wildife managers and other appropriate resource specialists. A similar recommendation to protect moist sites which are relatively far apart but evenly distributed over a summer range, as well as a security zone of cover around each site, may be impractical. However, it should be recognized that continual loss of these small units and their juxtaposition in the forest could in time have a substantial adverse impact on a local elk herd. Therefore, as many as possible of these sites should be identified and withdrawn from treatment, along with a peripheral zone to provide continuous cover with the uncut forest. New or planned roads passing near these sites should be closed to summer-fall vehicular traffic, except perhaps for light intermittent administrative use, following logging in the area. Roads which already occur near moist areas of either type described above should be closely evaluated for travel restrictions.

Discussion: Moist sites (wet sedge meadows, bogs, seeps, etc.) have been identified as a very important component of elk summer range especially when these sites occur within the Abies lasiocarpa climax series.

Preferred elk summer range exists when these moist sites are interspersed with other necessary habitat components including a diversity of timber types and densities, and perhaps dry broken or open parks, especially near drainage heads or other topographic entities where these conditions are found.

In terms of the biology of elk, sites near water are important because the forage they produce is heavily utilized by elk prior to the breeding season. Other studies indicate that nutrition obtained by the animals during this period is a-significant factor in reproduction. Generally, west of the Continental Divide early to mid-seral stages of the habitat types named above produce more forage. However, mature stands on moist sites also provide important cover, and removal of such stands may result in a decline or loss of elk use in the area. 


\section{ROAD LOCATION RECOMMENDATION!}

Research Finding:

Location and density of roads, and the use made of those roads, may be disturbing to elk depending on intensity, type, and season of use. E1k travel routes normally cross ridges through saddles and are usually easy to identify. When these saddles are opened up they tend to be avolded as crossing places for elk. Disturbance by road construction or hunting season traffic has resulted in declines or elimination of elk use in such places. Elk have indicated a preference for crossing ridges in sections where visibility is relatively low and security relatively high, of ten where dense timber is present. Alteration of such crossing areas can be especially critical during the hunting season.

Recommendation: During the location and design of transportation systems, existing elk movement patterns and probable elk crossing areas should be identified and provisions made to provide security for unimpeded movement. Where possible, several alternate routes should be considered. Primary considerations should be given to:
a. maintaining frequent dense cover areas adjacent to the road;
b. avolding saddles or low divides frequented by elk for cross- ing ridges between drainages;
c. maintaining cover at places where game trails cross roads;
d. utilizing a low standard slow speed, single track road that lays lightly on the ground in important elk areas; and
e. road right-of-way slash should be disposed of so as to not inhibit elk movement.

\section{HABITAT TYPE-COVER TYPE RECOMMENDATION}

\section{Research Finding:}

While the habitat type classification system gives a reasonable description of forest community composition and ecological potential, the structural characteristics, or cover type, can vary within habitat types by location and over time. Also, seral stages in different habitat types may be structurally similar. Elk use of cover types within and between habitat types is often specific, changing in both space and time during summer and fall. For example, moist sites may be kighly preferred from June through September but avoided in October and November while the relatively advanced seral stages and the more dense stands of timber may not be as important June through August as in the fall months.

Recommendation: Findings of this study indicate that plant community structure, or cover type, is of ten a more important factor than community composition, or habitat type, in determining elk use during summer and fal1. Management efforts based on what's going to be there (habitat type) should be well coordinated with an awareness of what's there (cover type) and a knowledge of spatial and temporal differences in elk use within and between habitat types. 
Discussion: Preserving or maintaining the interspersion, diversity, and juxtaposition of various habitat types and their successional stages or cover types cannot be overemphasized as an important elk management tool on important elk spring, summer, and fall range. When an attempt is made to quantify elk use-habitat type relationships it is very difficult to differentiate between the importance of individual habitat types and the importance of the overall interrelationships of these types with one another, not to mention the various stages of development or cover types within each habitat type. Important or key areas for elk must be identified before or during the planning and implementation of silvicultural practices.

\section{CLEARCUTS RECOMMENDATION}

\section{Research Finding:}

Graphic analyses of the number of elk pellet groups found inside clearcuts in eastern and western Montana have identified seven different variables that influence elk use of openings. All are important in some degree, but relative importance can vary depending on the environment available to elk and elk behavioral patterns associated with their environment.

In eastern Montana, for example, tree cover occupies a smaller proportion of the winter range and there is a more distinct separation between winter and summer ranges. Elk make relatively greater summer use of clearcuts at higher elevations as compared to western Montana where some elk remain on the winter range year around.

Throughout Montana elk range, slash within the opening and dead and down timber in the surrounding uncut forest reduced elk use. A preference for smal1 openings was indicated, particularly in western Montana, but cutting units as large as 100 acres may be acceptable under some circumstances.

Elk response to the growth of vegetation inside an opening differs between eastern and western Montana. The differences could be related to vegetation palatability but are more probably determined by the habitual feeding pattern of animals. Where new growth consists of both trees and shrubs and elk feed on browse, elk use of openings increases until vegetation is at least four feet high. Where new growth is mostly trees and elk feed primarily on grasses and forbs, elk use of openings declines as vegetation heightincreases. As a corollary to this indicated preference for openings lacking tall cover, eastern Montana elk responded to additional security provided by good cover adjacent to the opening and, further, demonstrated a substantial positive response to openings without motor vehicle access.

Recommendation: On the basis of available data, it is not possible to demonstrate that clearcuts in any configuration are clearly beneficial to elk. Neither is it possible to demonstrate detrimental effects if the openings satisfy certain criteria: 
xii

(1) Slash cleanup inside clearcuts should reduce average $\mathrm{slash}$ depth below 1.5 feet. Slash in excess of 1.5 feet will reduce elk use by more than 50 percent.

(2) Small openings appear to be preferred, but openings up to 100 acres may be acceptable where the adjacent forest is relatively free of understory debris and security is adequate.

(3) Security cover is required if elk are to enter any opening. In western Montana, some cover is provided by vegetation growth as the opening becomes older; but in eastern Montana elk prefer young openings and security should be provided by designing clearcuts so that the best available cover occurs at the edges. As a corollary, thinning adjacent to clearcuts is not recommended.

(4) Additional security, which will significantly increase elk use of openings in eastern Montana, can be provided with appropriate road closures.

\section{ROAD CLOSURE RECOMMENDATION}

Research Finding:

Two phases of the project involved area closures that restricted motor vehicles to a few selected roads during the hunting season.

The Judith Road Closure Study indicated that travel restrictions did not change elk distribution or temporal distribution of hunters. Apparently this area closure was not necessary to "protect" elk where escape cover was adequate and well distributed (at least $2 / 3$ cover to $1 / 3$ open). Hunters spent more time walking; consequently, they reported seeing and killing more elk under the restrictions than during the unrestricted seasons. Their unsolicited comments showed a preference for limited access because of the "higher quality" hunt it afforded.

The Ruby Road Closure Study, on the other hand, showed that area closures can cause significant changes in elk distribution and hunter use of the area. This area was characterized by a relatively open, broken forest with gentle terrain and easy access ( $1 / 3$ cover to $2 / 3$ open). During seasons of restricted travel, elk stayed in the restricted area longer and in greater numbers than during preclosure seasons. This resulted in a greater seasonlong uniformity (but not total amounts) of hunting pressure, elk sightings, and elk harvest. Hunters also spent more time walking during the restriction period. A trend toward these same changes was noted in the unrestricted travel zone of this study area. Most hunters interviewed felt that the area closure had increased the quality of their hunt.

Recommendation: E1k management goals and objectives should be clearly defined before imposing travel restrictions, being especially cognizant of the following:

I. Restrictions will:

1. increase the time spent walking by hunters, and as a result: 
a. increase the number of animals seen.

b. possibly increase the kill.

2. generally be accepted as providing a higher quality hunt.

3. make retrieval of killed antmals more difficult.

II. Where cover is good (at least $2 / 3$ of total area) and well interspersed, restrictions will probably have little effect on elk distribution.

III. Where cover is poor ( $1 / 3$ or less of total area) restrictions w111:

1. reduce harassment and emigration of elk.

2. probably reduce the early elk harvest, but increase the uniformity of harvest throughout the season.

Discussion: Road density and pattern, including off-road travel, play an important role in determining the security level an area provides to elk during the hunting season. An area with sparse cover and low road density may provide as much security as the same sized area with heavy cover but with high road density. For example, in the Ruby portion of this study the security level was significantly increased by reducing the road density and by eliminating off-road travel. Road density and cover quality are both important when considering adequate elk security during the hunting season.

Also, road closures in areas that change elk distribution in space and/or time must also change elk distribution in the adjacent area(s) (an elk can't be in two places at the same time). Therefore, closures may benefit hunters in one area at the expense of hunters elsewhere.

\section{WINTER RANGE RECOMMENDATION}

\section{Research Finding:}

Elk on winter range have been shown to prefer dense timber stands and larger trees for bedding cover. These bedding sites are usually in close proximity to a feeding area such as a south-facing slope with a good stand of browse or perennial grass. Timbered areas which received moderate to heavy elk-bedding use prior to logging were not used for bedding during winters following heavy selection logging. Elimination of these preferred bedding sites can subject elk to a decrease in energy intake and an increase in energy output because of increased travel between suitable bedding and feeding sites, lowered insulating value of bedding cover because of loss of large trees, and use of inferior food sources closer to new bedding sites.

\section{Recommendation:}

Because of the relative importance of productive elk winter range and the narrow margin for error, any contemplated modification should be planned on a site by site basis with primary emphasis on maintaining adequate thermal cover adjacent to productive forage areas. 
xiv

On important and already well used winter ranges, the probability of

improvement is usually minimal. Where winter range quality is declining or is already suboptimum, especially on shrub ranges, several management options offer possibilities for enhancing winter range.

Timbered areas adjacent to primary foraging areas should be managed to provide thermal cover. The presence of larger trees in a multistory stand is desirable.

Where forage conditions are poor, the timber overstory can be removed in small patches to enhance forage production. The design and layout of these openings should be planned so that adjacent forest cover on benches and finger ridges will provide thermal cover and bedding sites. Slash cleanup should be relatively complete and logging should be scheduled outside the winter period.

\section{ELK-CATTLE RECOMMENDATION}

\section{Research Finding:}

Findings from investigations to determine seasonal elk distribution have indicated that the presence and distribution of domestic cattle has substantially influenced the distribution of elk on summer range. Systematic observation revealed a significant tendency for elk to avoid cattle. Movement of cattle into areas being used by elk caused displacement of the elk into areas where cattle had not been or would not be.

Recommendation: Road construction and/or other associated timber harvest activities occasionally "open up" new areas for grazing or alter existing cattle grazing allotments on elk summer ranges, increasing the potential for elk-cattle interaction in such areas. The effect of every proposed timber sale on $e l k$ and livestock management objectives and programs should be evaluated. If potential elk-livestock conflicts are identified as a result of proposed timber harvest, the conflict should be resolved on a case-by-case basis. 


\section{INTRODUCTION}

The objectives of this job are to identify the basic conflicts between timber harvest and elk ecology in the various forest types of Montana, and to plan and coordinate research efforts.

With the compilation of this report, the Montana Cooperative Elk-Logging Study has completed nine years of field investigation. Currently, only two studies remain active, but analyses and publication continue in several other jobs.

Job I.

Coordination. On-going for the life of the project.

Job II-A.

Burdette Creek-Deer Creek. Completed. Two manuscripts published in 1979.

Job II-B.

Long Tom Creek. Logging was completed; final year of study in progress.

Job II-C.

Sapphire Mountains. Completed.

Job II-D.

Chamberlain Creek. Road-building completed; logging in progress. One manuscript published in 1979.

Jobs III-A-1 and A-2. Judith and Ruby road closures. Completed.

Job III-B.

Distumbed areas. Completed. Manuscript accepted by the Journal of Wildlife Management; to be published in 1980.

Job IV. Spotted Bear. Completed.

COMMITTEES

The project Steering Committee for 1979 included the following members:

Intermountain Forest and Range Experiment Station

Bureau of Land Management

Montana Department of Fish and Game

School of Forestry, University of Montana

Region 1, USFS
Ralph Klawitter, Chairman Don McIntosh

Eugene 0. Allen

W. Leslie Pengelly

Edward Schneegas

The project Research Cormittee for 1979 included the following members:

Intermountain Forest and Range Experiment Station

L. Jack Lyon, Chaiman 
Montana Department of Fish and Game

Bureau of Land Management

School of Forestry, University of Montana

Region 1, USFS
John P. Weigand

Jack Jones

Darrel Sall

C. Les Marcum

Not represented

\section{ACTIVITIES}

Meetings

$\begin{array}{lll}\text { Date } & \text { Location } & \text { Meeting } \\ \text { April } 4 & \text { Helena } & \text { Steering Conmittee } \\ \text { August 14-15 } & \begin{array}{l}\text { Long Tom area and } \\ \text { Haggen Ranch }\end{array} & \text { Steering Conmittee }\end{array}$

In addition, various members of the Research Comittee met or attended other meetings or workshops to discuss results of the study. The following presentations were made:

Presentations

Date

March 12-13

March 22

April 4

April 18

May 1

May 8

May 14

June 5

July 12

September 13

October 15

October 16

October 17

December 7
Organization

Salmon-Challis biologists CEFES ( $R-1$ silviculturists)

YACC, Missoula

University of Montana, Wildlife class

University of Montana, Habitat Typing class

Max Peterson, USFS

Yale University field trip

Flathead National Forest resource staff

Iowa State University sumer camp

Residues Symposium, Missoula

University of

Montana Section, SAF

University of Montana, Wildlife class

BIA biologists
Speaker

Lyon

Lyon

Marcum

Marcum

Lyon

Lyon

Lyon

Lyon

Lyon

Basile

Lyon

Marcum

Lyon

Publications

- . corrected title from 1978 report:

Marcum, C. Les. 1979. Sumer-fall food habits and forage preferences of a western Montana elk herd. In North American Elk: Ecology Behavior and Management, M.S. Boyce and L.D. Hayden-Wing, eds. Univ. of Wyoming, Laramie. p. 54-62. 
-. new titles:

Lieb, J.W., and C.L. Marcum. 1979. Biotelemetric monitoring of heart rate and activity in elk. Pages 21-32 in Proc. Sec. Internat. Conf. on Wildl. Biotelemetry. Univ. of Wyaning, Laramie.

Lyon, L. Jack. 1979. Influences of logging and weather on elk distribution in western Montana. USDA Forest Serv. Res. Pap. INT-236. 11 pp.

- 1979. Habitat effectiveness for elk as influenced by roads and cover. J. For. 77(10):658-660.

Research Committee. 1979. Montana Cooperative Elk-Logging Study, Annual

Progress Report, Jan. 1-Dec. 31, 1978. 106 pp.

\section{Other Activities}

During 1979, Region 1 contracted to have the slide presentation describing results and management recommendations of the Montana study produced as a slide-tape. A total of 40 copies were made. Five were distributed to National Forests in Region I, 26 to other Regions of the Forest Service (20 to Region 4), one each to the Wildiife Management Institute, University of Montana library, and members of the Steering committee. Several were retained by Region 1 as loan copies.

Duplicate entries were purged from the computerized bibliography. A total of 449 citations are now included. Instructions for using this bibliography, Keyword lists, loan of the magnetic tape, or hand copy are available (cost about \$15). Contact:

Terry Lonner

Montana Department of Fish, Wildlife and Parks

Box 5, MSU Campus

Bozeman, Montana 59717 


\author{
$-4-$ \\ JOB II-B \\ LONG TOM CREEK STUDY \\ PROGRESS REPORT FOR THE PERIOD \\ JANUARY 1, 1979 - DECEMBER 31, 1979
}

\title{
Introduction
}

The objectives of this study are to determine the environmental requirements of $\mathrm{elk}$ and the effects of logging on an elk population in the scattered forest type of Long Tom Creek in southwestern Montana. On the ground field work has been conducted from June or early July-0ctober each year, 1972-1979. Aerial surveillance has occurred at least once a month since the beginning of the study to locate radioed $e 1 \mathrm{k}$ and/or measure the general elk distribution and herd composition. The years 1972, 1973, and 1974 were pre-logging years even though some minor road construction began in the extreme southern portion of the study area in 1974. Logging activity primarily began in the summer of 1975 and continued in 1976 and 1977, so these years were considered logging years. Minor logging activity with some slash piling occurred in the fall of 1978, but this year was still considered the first post-logging year of the study. No logging activity occurred during the summer of 1979. Since the new logging road was built, it has been closed (with a gate) to motorized public access. It is probable that during July and August, 1980 , the new logging road will be opened to public use for firewood gathering from slash caused by the logging. The road will, however, be closed again in early September before any hunting season openings. A11 other road systems in and adjacent to the study area have remained open since the beginning of the study.

Description of the Study Area

Long Tom Creek, located about 25 miles southwest of Butte, Montana, is a side drainage of Jerry Creek which flows southerly and empties into the Big Hole River near the village of Wise River (Fig. 1). Elevations range from 7,000 to 9,100 feet with the Continental Divide forming the north boundary of the study area. The Long Tom Creek-Upper Johnson Creek study area comprises about 36 square miles and consists of a series of heavily timbered ridges of moderate relief. A variety of cover and habitat types are represented including lodgepole pine, Douglas-fir, subalpine fir, whitebark pine, Engelmann spruce, and combinations thereof as dominant overstory species. The area is interspersed with numerous small, wet sedge meadows and bogs, parks, rocky ridges and open, south-facing sagebrush and grasscovered slopes. Clearcut logging has occurred in the head of Jerry Creek to the east and in lower Johnson Creek to the south and southwest. The only public vehicle access to the area is by 4-wheel drive from the east and northeast during periods of relatively dry road conditions. The study area is a portion of Hunting Unit 319 and is mostly 


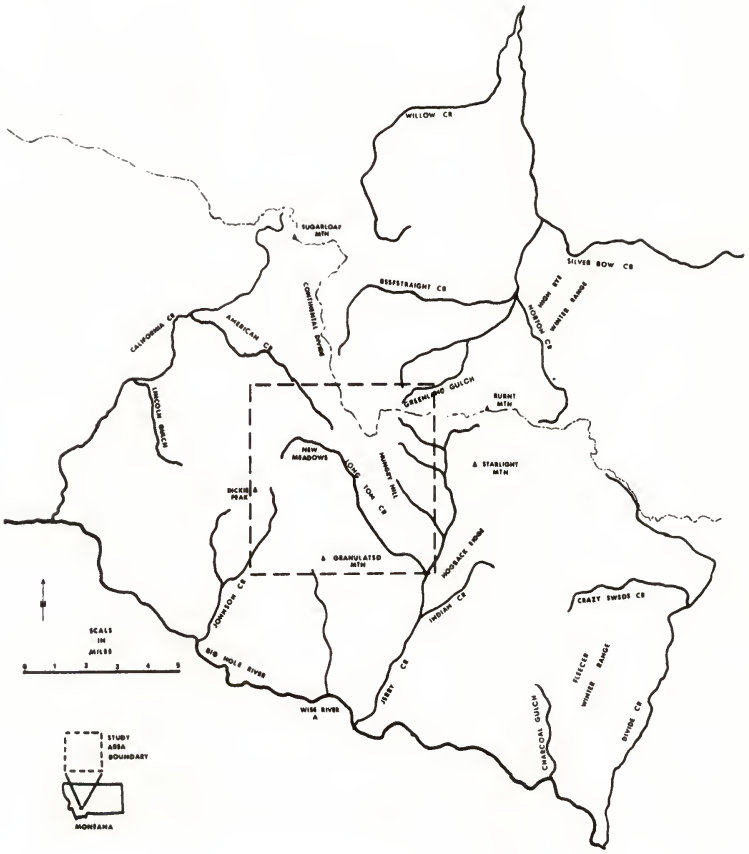

Figure 1. Vicinity of the Long Tom Creek Study area. 
on the Beaverhead National Forest with a small portion to the north located on Deerlodge National Forest land.

\section{Methods}

As during previous field seasons elk use of the study area was determined in 1979 primarily from "elk sign" recorded while periodically and systematically walking 62 miles of foot routes that were established during the first field season in 1972. During the 1979 field season the route system was walked four times between June 28 and October 5 . In previous years the number of times the route system was walked and used for data analyses were 3 in 1972, 6 in 1973 and 1974, 4 in 1975, 5 in 1976, and 4 in both 1977 and 1978. Pellet group counts combined with other elk sign observed (tracks, bed sites, animal observations, wallows, and rubbed trees) were used as the primary method to sample elk use of the study area via the route system. Duplication of recording the same elk use from one replication to another has been avoided when possible.

A detailed explanation of the route system and how elk use was recorded while walking the routes was presented in the 1976 progress report (Lonner 1976). Several other measurements have been made of the immediate area sampled by the route system. Measurements and their completion status are presented in Table 1 .

Forage quality and quantity measurements were made during the $1979 \mathrm{field}$ season as part of a Montana State University graduate student research project. Methods used in this study are explained in the thesis (Hammond 1980).

Radio telemetry work has continued to gather detailed information on distribution and movements of radio-equipped elk. A total of 17 elk were initially tracked at the beginning of the 1979 field season, but by the end of the year we had lost 5 of these; 3 probably had transmitter failure and 2 were shot during the hunting season. of the elk tracked, one was collared in 1973 and recollared during 1979, one was collared in 1974 and recollared in 1978, one was collared in 1975 and recollared in 1979, one was collared in 1977, 8 in 1978, and 5 in 1979. A11 but 3 were cows. Further information on these elk is presented in Table 2 . As in previous years all active radios were tracked at weekly intervals from mid-April to early December with tracking continued through the winter months but at about a three-week interval. This involved $36 \mathrm{flights}$ in a Super Cub from May 1, 1979 to April 30, 1980. Transmitters were put on using a helicopter and capture gun during early spring.

Triangulation was again used to gather around-the-clock information on daily movements of individual radio-collared elk. This was accomplished by making bihourly (every two hours on the two hours) relocations during seven triangulation sessions ranging in length from 14 hours to 50 hours. This involved three or four fixed-base stations located on high points in or near the study area. These base stations were equipped with nul1peak antenna systems purchased from AVM Instrument Company of Champaign, Illinois. A further explanation of this system is described by Pac in the 
Table 1: List of variables measured or to be measured for some or all of the 700 segments composing the foot route system in the Long Tom Creek study area.

Elk use (pellet groups and general impression) 1 Deer use (pellet groups, observations, tracks) 1 Cattle use (droppings, observations, tracks) ${ }^{1}$

Forage use ${ }^{1}$

Wetness type 1

Wetness degree 1

Segment length ${ }^{2}$

General cover type 2

Habitat type ${ }^{2}$

Density of trees by species and by dbh and height classes ${ }^{2}$

Canopy coverage ${ }^{2}$

Tree stand age

Distance to closest cutting unit and/or new mainline road ${ }^{2}$

Sight distance ${ }^{2}$

Downfa $11^{2}$

Ground cover or understory vegetation (largely explained by Aspect ${ }^{2}$ habitat type $)^{2}$

Configuration ${ }^{2}$

Topography ${ }^{2}$

slope $(\%)^{2}$

Size of opening (park, broken park, clearcut) segment passes through (if applicable) ${ }^{2}$

Security index for primary foraging areas (al1 segments but timbered ones) ${ }^{3}$

Forage quality and quantity measurements of general vegetation types $^{3}$

Indices of interspersion, diversity, and homogeneity for each segment of the route system ${ }^{3}$

UTM coordinates for the center of each segment ${ }^{2}$

${ }^{1}$ Measured each time segment is surveyed.

2 Measurements are completed.

${ }^{3}$ Measurements are partially complete. 
Table 2. Some gereral statistics and seasonal movement and home range calculations from radio-tracking $28 \mathrm{elk}$ in management unit 319 since spring, 1973.

\begin{tabular}{|c|c|c|c|c|c|c|c|c|c|c|c|c|c|c|c|c|c|c|c|c|c|c|c|}
\hline \multirow{3}{*}{$\begin{array}{l}\text { Radioed Elk } \\
\text { Channel No. } 6 \\
\text { Year Tracked }\end{array}$} & \multirow[b]{3}{*}{ Sex } & \multirow[b]{3}{*}{ Age } & \multirow{3}{*}{$\begin{array}{l}\text { Winter Range } \\
\text { Where } \\
\text { Collared }\end{array}$} & \multicolumn{4}{|c|}{ Spring } & \multicolumn{4}{|c|}{$\begin{array}{l}\text { Sunmer } \\
\text { June 16-Sept.3 }\end{array}$} & \multicolumn{4}{|c|}{ Fall } & \multicolumn{4}{|c|}{ Winter } & \multicolumn{4}{|c|}{$\begin{array}{l}\text { Spring-Fal1 } \\
\text { May L-Dec. } 1\end{array}$} \\
\hline & & & & \multirow{2}{*}{\multicolumn{4}{|c|}{$\begin{array}{l}\text { May } 1-\text { June } 15 \\
\text { On } \\
\text { No. }{ }^{1} \text { Area }^{2} \text { Per }^{3} \mathrm{SD}^{4} \\
\end{array}$}} & \multicolumn{4}{|c|}{$\begin{array}{c}\text { June 16-Sept. } 30 \\
\text { On }\end{array}$} & \multicolumn{4}{|c|}{ Oct. 1-Dec. } & \multicolumn{4}{|c|}{$\begin{array}{c}\text { Dec. 2-April } 30 \\
\text { On }\end{array}$} & \multicolumn{4}{|c|}{$\begin{array}{c}\text { May 1-Dec. } 1 \\
\text { On }\end{array}$} \\
\hline & & & & & & & & No. & Area & Per & $S D$ & No. & Area & Per & SD & No. & Area & Per & SD & No. & Area & Per & SD \\
\hline $\begin{array}{l}178-78 \\
178-79 \\
\end{array}$ & M & 2 & Fleecer & $\begin{array}{l}6 \\
6 \\
\end{array}$ & $\begin{array}{l}28.4 \\
31.1 \\
\end{array}$ & $\begin{array}{l}5 \\
6 \\
\end{array}$ & $\begin{array}{l}12.7 \\
13.3 \\
\end{array}$ & $\begin{array}{l}15 \\
14 \\
\end{array}$ & $\begin{array}{l}20.9 \\
22.3 \\
\end{array}$ & $\begin{array}{l}5 \\
5 \\
\end{array}$ & $\begin{array}{r}5.2 \\
5.6 \\
\end{array}$ & $\begin{array}{l}7 \\
5 \\
\end{array}$ & $\begin{array}{l}24.1 \\
19.6 \\
\end{array}$ & $\begin{array}{l}4 \\
4 \\
\end{array}$ & $\begin{array}{r}8.5 \\
11.2 \\
\end{array}$ & 8 & $\begin{array}{l}2.6 \\
\text { Eik }\end{array}$ & $\begin{array}{c}5 \\
\text { dead }\end{array}$ & 2.2 & $\begin{array}{l}28 \\
25 \\
\end{array}$ & $\begin{array}{l}72.6 \\
91.2 \\
\end{array}$ & $\begin{array}{l}7 \\
7 \\
\end{array}$ & $\begin{array}{r}9.3 \\
10.6 \\
\end{array}$ \\
\hline $274-74$ & $\mathbf{F}$ & Ad & Fleecer & 5 & 10 & 3 & 5.4 & 8 & 1.4 & 4 & 1.4 & & $<3$ & Fixe & & & & & & 15 & 18.1 & 5 & 5.7 \\
\hline $274-75$ & & & & 5 & 11.8 & 5 & 5.7 & 20 & 10.8 & 7 & 3.5 & 7 & 7.2 & 4 & 4 & 5 & .5 & 3 & 1.3 & 32 & 35.1 & 7 & 6.8 \\
\hline $274-76$ & & & & 6 & 12.7 & 4 & 5.8 & 19 & 5 & 7 & 3.2 & 9 & 6 & 6 & 3.1 & 9 & 16.2 & 6 & 7.3 & 34 & 19.5 & 6 & 4.3 \\
\hline $274-77$ & & & & 6 & 4.3 & 4 & 3.1 & 12 & 6.3 & 7 & 3.6 & 7 & 6.9 & 5 & 4.9 & 7 & 10.4 & 5 & 4. & 25 & 18 & 9 & 4.9 \\
\hline $274-78$ & & & & 6 & 17.9 & 4 & 7.9 & 14 & 3 & 7 & 2.7 & 7 & 1.6 & 4 & 1.9 & 8 & 2.3 & 5 & 2.2 & 27 & 25.2 & 6 & 4.6 \\
\hline $274-79$ & & & & 7 & 18.1 & 5 & 6.5 & 16 & 6.9 & 7 & 3.1 & 8 & 8.6 & 6 & 4.4 & 7 & 8.9 & 5 & 5.2 & 31 & 29.4 & 12 & 5.6 \\
\hline $278-78$ & $\bar{F}$ & 6 & Fleecer & 6 & 1.8 & 5 & 3.2 & 21 & 33.5 & 9 & 10.4 & 7 & 3.1 & 3 & 2.4 & 8 & 3 & 6 & 2.7 & 34 & 39.2 & 9 & 9.3 \\
\hline $278-79$ & & & & 7 & 36.2 & 5 & 16.9 & 14 & 47.4 & 5 & 14.2 & 7 & 9.6 & 4 & 4.8 & 7 & 10.8 & 6 & 5.4 & 28 & 71.4 & 6 & 14.3 \\
\hline $376-76$ & F & 1 & Fleecer & 7 & 19.7 & 6 & 6.3 & 16 & 24 & 6 & 4.5 & 9 & 10 & 4 & 3.8 & 9 & 5.9 & 5 & 4.6 & 32 & 41.1 & 6 & 5 \\
\hline $376-77$ & & & & 6 & 2.9 & 5 & 3 & 14 & 8 & 7 & 3.1 & 8 & 1.2 & 4 & 1.4 & 7 & 2 & 6 & 2. & 28 & 10.8 & 7 & 3.4 \\
\hline $376-78$ & & & & 6 & 2.3 & 5 & 2.4 & 16 & 15 & 7 & 4.1 & 7 & 5.4 & 6 & 3.1 & 3 & .3 & 3 & 6.7 & 29 & 18.5 & 8 & 3.8 \\
\hline $476-76$ & M & 2 & Fleecer & 7 & 11.8 & 4 & 5.8 & 17 & 16.9 & 6 & 6.1 & 9 & 9.2 & 7 & 5.7 & 9 & 2.7 & 5 & 1.9 & 33 & 26.6 & 8 & 6.6 \\
\hline $476-77$ & & & & 6 & 2.7 & 5 & 3.3 & 14 & 14.1 & 6 & 5 & 5 & .5 & 5 & 1.7 & & E1k & dead & & 25 & 20.7 & 5 & 4.8 \\
\hline 479-79 & $F$ & $8-10$ & Fleecer & 7 & 17.6 & 5 & 17.6 & 15 & 6.2 & 8 & 3.2 & 8 & 5.1 & 6 & 4.5 & 7 & 10.0 & 6 & 6 & 30 & 25.7 & 9 & 5.6 \\
\hline 578-78 & F & 6 & Pleecer & 6 & 2.8 & 4 & 5.4 & 15 & 20 & 6 & 4.8 & 7 & 6.2 & 4 & 3.6 & & E1k & dead & & 28 & 27.5 & 9 & 5.5 \\
\hline $579-79$ & $M$ & 2. & Fleecer & 6 & 77 & 6 & 23.4 & 6 & 9.0 & 4 & 5.7 & & $\overline{\text { ost si }}$ & nal & after & 8711 & & & & & & & \\
\hline $675-75$ & F & 2 & Fleecer & 5 & 1.1 & 4 & 3.1 & 15 & 6.9 & 7 & 2.8 & 7 & 6.3 & 5 & 4.3 & 5 & .8 & 3 & 1.6 & 27 & 17.2 & 5 & 3.9 \\
\hline $675-76$ & & & & 6 & 3.9 & 6 & 3.1 & 15 & 5.3 & 6 & 2.7 & 9 & 2.9 & 6 & 2 & 9 & 8.4 & 5 & 3.9 & 30 & 10.9 & 7 & 2.8 \\
\hline $675-77$ & & & & 6 & 6.7 & 5 & 3.6 & 4 & 2.5 & 4 & 2.8 & & adio $\mathrm{g}$ & uit - - & & & & & & & & & \\
\hline $678-78$ & $\mathbf{F}$ & 7 & Fleecer & 6 & 8.3 & 5 & 4.8 & 15 & 8.8 & 6 & 3.4 & 7 & 4.8 & 4 & 4.2 & 3 & 5.4 & 7 & 4. & 28 & 27.3 & 6 & 4.8 \\
\hline $678-79$ & & & & 7 & 5.8 & 6 & 4.9 & 14 & 7.3 & 6 & 3.2 & 7 & 2.3 & 4 & 3.2 & 7 & 26.7 & 5 & 8.1 & 28 & 21.1 & 9. & 4.7 \\
\hline $778-78$ & F & 2 & Fleecer & 6 & 4.6 & 6 & 4.5 & 16 & 30.5 & 7 & 5.5 & 7 & 9 & 4 & 3.8 & 7 & 2.4 & 4 & 2.2 & 29 & 38.9 & 6 & 5.4 \\
\hline $778-79$ & & & & 7 & 9.7 & 4 & 8.1 & 13 & 3.3 & 4 & 1.8 & & Iadio 9 & uit-- & & & & & & & & & $\rightarrow$ \\
\hline $878-78$ & $\mathbf{F}$ & 6 & Fleecer & 6 & 7.1 & 3 & 5.5 & 15 & 5.2 & 5 & 2.7 & 7 & 2.5 & 4 & 3.3 & 8 & 14.6 & 5 & 9.2 & 28 & 23.5 & 5 & 4.5 \\
\hline $878-79$ & & & & 7 & 5.6 & 6 & 3.5 & 15 & 8.8 & 6 & 3.6 & 7 & 14.1 & 5 & 4.8 & 7 & 56 & 4 & 10.3 & 29 & 35.8 & 8 & 5.1 \\
\hline $1117-77$ & $\mathbf{F}$ & 7 & Fleecer & 6 & 9.8 & 4 & 5.6 & 15 & 14.7 & 7 & 5.8 & 8 & 12 & 5 & 6.7 & 7 & 10.4 & 5 & 4.7 & 29 & 21.7 & 5 & 6 \\
\hline $1117-78$ & & & & 6 & 6.5 & 4 & 3.7 & 9 & 2 & 4 & 2.1 & & lad1o $\mathrm{g}$ & uit-- & $-\cdots$ & -1 & $\cdots$ & - & $-\cdots$ & $\cdots$ & $-\cdots$ & -- & $\rightarrow$ \\
\hline $1175-75$ & $\mathbf{F}$ & Ad & Fleecer & 5 & 1.2 & 3 & 2.8 & 19 & 9.9 & 8 & 3.8 & 7 & 10.6 & 6 & 6.1 & 6 & 1.8 & 4 & 2.1 & 31 & 30.1 & 8 & 7.2 \\
\hline $1175-76$ & & & & 6 & 13.9 & 5 & 6.6 & 18 & 4.5 & 10 & 3.2 & 9 & 7.3 & 6 & 3.2 & 9 & 12.2 & 5 & 6 & 33 & 25.9 & 9 & 5 \\
\hline $1175-77$ & & & & 6 & 10.7 & 4 & 6.9 & 15 & 12.2 & 6. & 4.8 & 3 & .5 & 3 & 1.6 & & E1k & dead & & 24 & 21.1 & 7 & 6.2 \\
\hline $1177-77$ & $\mathbf{F}$ & 7 & F1eecer & 4 & 7.1 & 3 & 8.6 & 13 & 6.5 & 8 & 3.7 & 7 & 11.4 & 4 & 10.5 & 5 & 14.1 & 4 & 11.4 & 24 & 106 & 6 & 11.1 \\
\hline $1177-78$ & & & & 3 & 13.3 & 3 & 10.5 & 17 & 42.7 & 4 & 7.3 & 7 & 8.3 & 4 & 5.9 & 8 & 45.9 & 6 & 12.5 & 27 & 101 & 6 & 8.9 \\
\hline $1179-79$ & $\mathbf{F}$ & $6-8$ & Fleecer & 6 & 23 & 4 & 13.4 & 15 & 12.7 & 8 & 4.1 & 7 & 7.8 & 4 & 10.3 & 7 & 6.3 & 4 & 10 & 28 & 50.3 & 11 & 11 \\
\hline
\end{tabular}




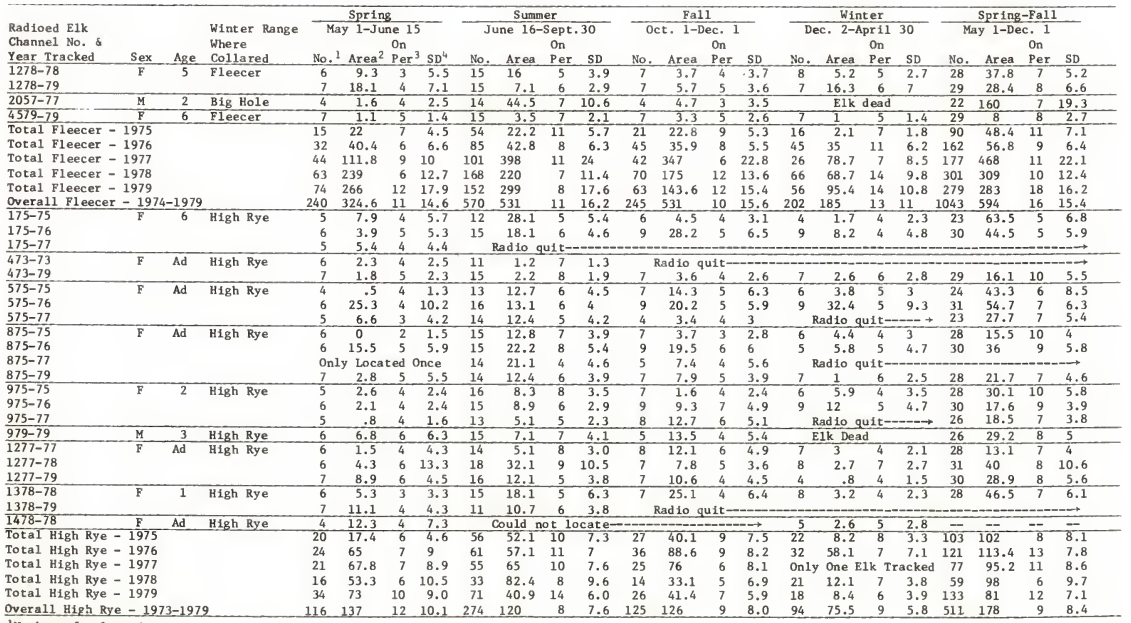

Overall High Rye - 1973-1979

Number of relocations.

Area in square miles based on connecting perimeter locations to form a polygon.

${ }^{4}$ Standard diameter in miles. 
1978 Proceedings of the Montana Chapter of The Wildlife Soclety's annual meeting.

More tests for determining the accuracy of this method to locate radioequipped elk were conducted during the 1979 field season. Twenty-four tests were made comparing simultaneous relocations of radio-equipped elk made from a Super Cub and the triangulation system. An additional 10 tests were made comparing transmitter locations made by a person either driving or hiking in the study area with those made by the triangulation system. The person carrying a transmitter would record his location every half hour on the half hour and the people on the stations would record signal azlmuths corresponding to these times. Errors ranged from .04 to $1.8 \mathrm{miles}$ with an average of $.62 \mathrm{miles}$ for all 34 tests. Forty-four percent $(15 / 34)$ of the tests were equal to or less than .5 miles and $82 \%(28 / 34)$ were equal to or less than 1 mile (Figure 2). During the 1978 field season, 17 of 21 tests or $81 \%$ showed an error of .5 miles or less with an average error of .4 miles (Lonner, 1979). Although these tests indicate the triangulation results too inaccurate for measurement of specific habitat use, the results are useful to index general bihourly and daily movement, distribution, and activity patterns.

Hunter questionnaires were again filled out on opening day of the general big game season at six check stations located near the Long Tom Creek study area. Simflar surveys were conducted in 1972 through 1978 and w111 be continued throughout the study.

As in 1974 and 1976-78, elk use adjacent to the proposed or new logging road was measured by $27 \mathrm{six}$ foot wide belt transects. These transects were established in 1974 and are approximately $1 / 4 \mathrm{mile}$ apart, extending 200 yards (paces) on each side and perpendicular to the road. This sampling system primarily records fall use (persistent pellet groups) made by elk during the previous fall(s). These transects will continue to be measured toward the end of the summer each year for the duration of the study.

Analysis of data has been and will continue to be done using two Montana State University computers; one located at the main computing center and the other in the Industrial Engineering Department. Several programs have been or are being developed to assist with the analysis and final report preparation.

\section{Findings to Date}

E1k Distribution and Response to Weather

The single factor thus far measured to influence overall elk use of the study area is weather. When precipitation was high from October-August immediately preceeding and during a field season, summer-early fall elk use tended to be low and vice versa. A linear correlation coefficient of -.58 was calculated to statistically measure this relationship (Fig. 3). Marcum, et al (1979) found a similar relationship in the Chamberlain Creek Study Area just east of Missoula, Montana. This relationship is probably more a result of how long the study area is 


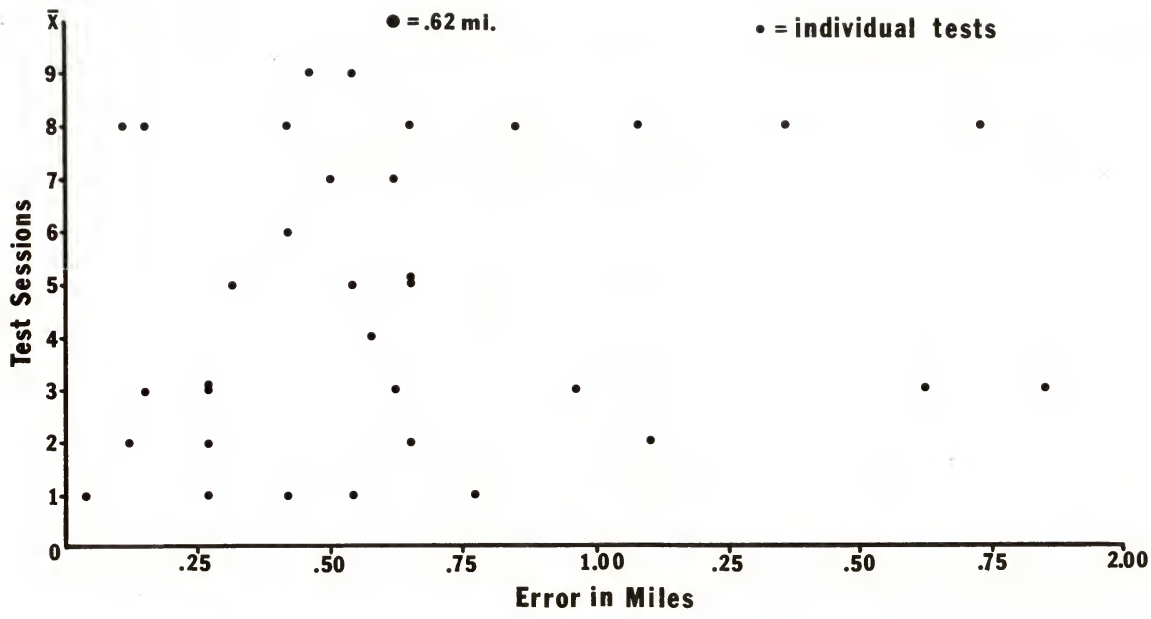
movements of radio collared elk in or near the Long Tom Creek study area. 


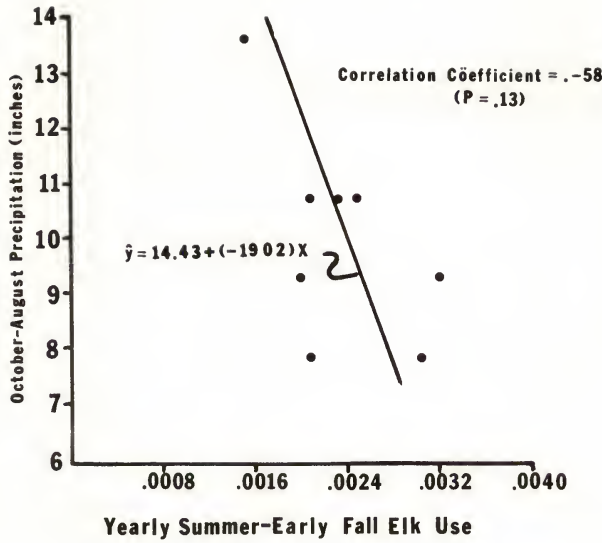

Figure 3. Relationship between yearly summer-early fall elk use and precipitation in the Long Tom Creek study area. (Precipitation measurements from a weather station 5 miles SE of the study area.)

physically available to the elk due to the lack of inhibiting deep snow than because of yearly phenological differences in the development of the vegetation used as forage. However, this argument is like what came first, the chicken or the egg, since spring-summer phenological progression of the vegetation is also very dependent upon winter-spring precipitation amounts.

Elk Distribution and Response to Logging

Overall summer-early fall elk use of the study area in 1979 was fourth highest since the beginning of the study (Figure 4). Although the yearly summer-early fall elk use of the study area has varied, the distributional pattern of how elk used the area remained fairly consistent. However, some changes occurred that appear attributable to the logging activity and are illustrated by figure 5 . (The consistent lack of elk use as shown in figure 5 in the southeast, southwest and northwest corners of the study area is because the route system did not sample these areas, consequent $1 y$ an interpolation of zero elk use was made.) The most obvious changes 


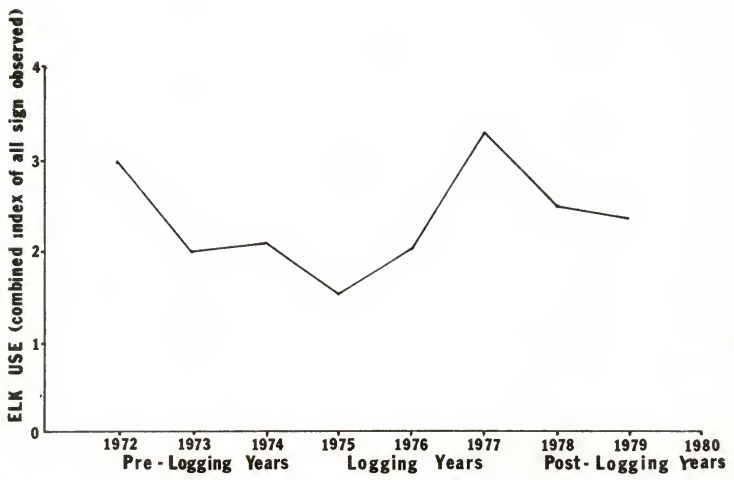

Figure 4. Yearly summer-early fall elk use of the Long Tom Creek study area.

in elk use of the study area that may have been caused by the logging activity were within about 2 miles of the sale area. One of these changes was an increase of elk use that became prominent during the 2nd and $3 \mathrm{rd}$ logging years (1976 and 1977) in the northcentral portion of the area. This increase of elk use nearly disappeared by the 2 nd post logging year. Another change appeared in the central portion of the area just east of the last $1 \mathrm{mile}$ of the mainline logging road. A reduction in use here started in 1976, the 2nd logging year, and has since remained. Elk use of a ridge to the east of and overlooking the sale area (SE quarter of study area) became depressed during the first logging year in 1975 and remained so even during the first post-logging year in 1978. During 1979 elk use reappeared in this area similar to the prelogging years of 1972-1974 (Fig. 5).

Results of the road cross transect surveys indicate elk avoided the immediate area near the timber sale as a result of logging activity. Fall use was the main response variable used in this analysis, since sampling primarily recorded the existence of persistent or actual pellet groups. The amount of elk use adjacent to the proposed or newly constructed logging road was described by assigning each road cross transect to one of three zones for a better measurement of elk response 


\section{PRE-LOG G I N G}
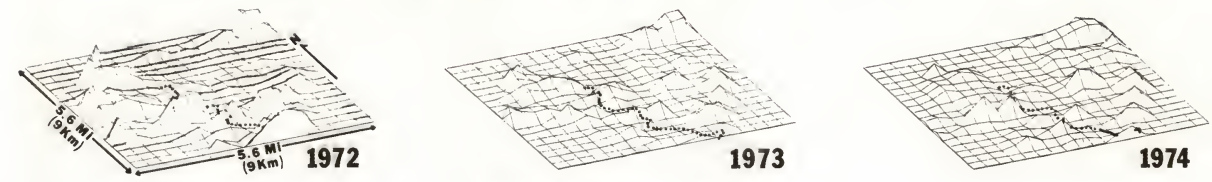

\section{O G G I N G}
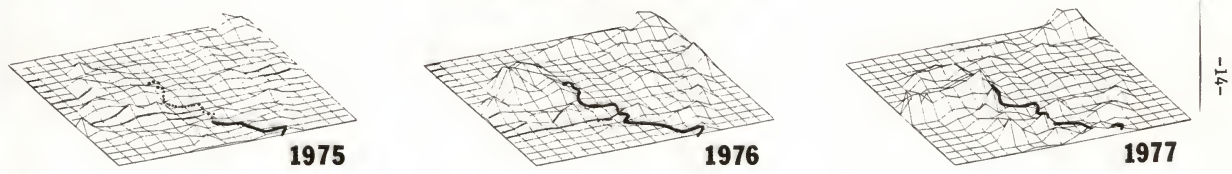

POS T-LOG G IN G
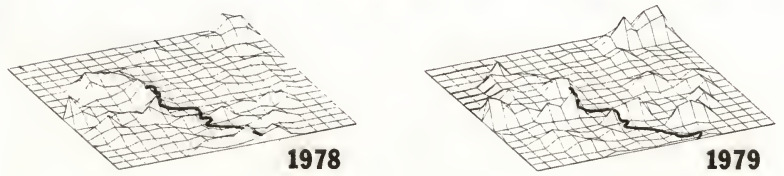

Figure 5. Three dimensional displays of summer-early fall elk use in the Long Tom Creek study area for 1972 - 1979. The elk use is expressed as mountainous relief and the new road is represented as either proposed (dotted line) or under construction or completed (solid line). 
to the logging progress and activity immediately adjacent to the proposed or new road (Fig. 6). As road construction and/or logging activity progressed into the study area starting in 1975, elk use correspondingly declined adjacent to the new road. Use in zones with logging traffic only also remained suppressed. Although there was no logging activity in 1978 and the road was closed to public use by motor vehicle, elk use still remained substantially lower than that during the pre-logging and first logging years (Fig. 7). This may indicate the reduced elk use of the sale area to be a conditioned response of the elk to human alteration of an area, regardless whether humans were present or absent.

Summer-early fall (June 15 - Sept. 30) relocations of 14 radio-equipped elk tracked for at least 2 years in or near the study area have demonstrated a strong individual affinity to the same summer range area. This affinity or orstreue (fidelity to place) appeared unaffected by the active logging or the alteration of the area after the Long Tom Creek timber sale was complete (Figs. 8-12). As indicated by figures 8,9 , and 10, those elk (numbers 473, 274, 175, 575, 675, and 1175) tracked before or at the start of the logging activity did not use the sale area to begin with and were located most of the time at least 1 mile away from this area. This is consistent with the analysis of the route system data, in that elk use of the area immediately in, or adjacent to, the timber sale was also low before logging activity began (Fig. 5).

\section{Other Telemetry Results}

Just over 2000 relocations of 36 radio-equipped elk have been recorded since the spring of 1973. Eleven of these elk wintered on the High Rye Winter Range and involved 668 relocations, while the remaining 25 were from the Fleecer Winter Range area and totaled to 1,335 relocations. The spring-fall area of distribution for elk from both of these winter ranges has thus far proven to overlap considerably, although the Fleecer elk have been the most far ranging with a total polygon area of 605 square miles compared to 181 square miles for the High Rye Elk (Fig. 13).

Seasonal fidelity of 20 radio-collared elk tracked for at least two field seasons was high with results similar to those reported last year (Lonner, 1979). Fidelity was highest for the summer-early fall season (June 16 - Sept. 30) with each individually collared elk demonstrating a marked desire to summer in the same area year to year. The tendency of these elk to winter in the same area year to year has also been very strong with no interchange of winter ranges yet observed.

As Table 2 shows, seasonal home range sizes have varied substantially, especially between elk year to year. The home range area based on connecting perimeter locations to form a polygon has ranged from near 0 to $77 \mathrm{mi}^{2}$ for the spring season (May 1 - June 15), $1.2-47 \mathrm{mi}^{2}$ for the summer season (June 16 - Sept. 30), .5 - $24 \mathrm{mi}^{2}$ for the fall season (Oct. 1 - Dec. 1), $3-56 \mathrm{mi}^{2}$ for the winter season (Dec. 2 - April 30), and $10.8-160 \mathrm{mi}^{2}$ for the spring-fall seasons combined. Home range sizes expressed by the standard diameter method were not as varied as the polygon method, since this method of measuring home range size is 


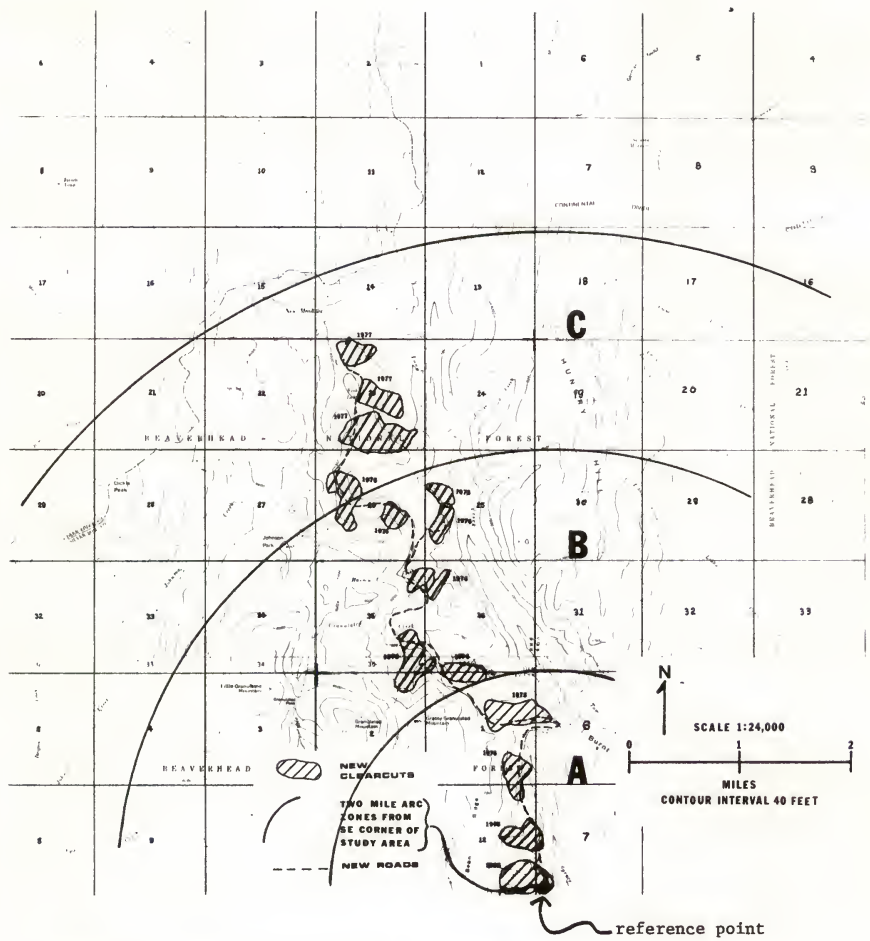

Figure 6. Layout of the Long Tom Creek timber sale and two mile zones used to measure elk distribution in response to logging progress into the study area. (Year cut is next to each clearcut.) 


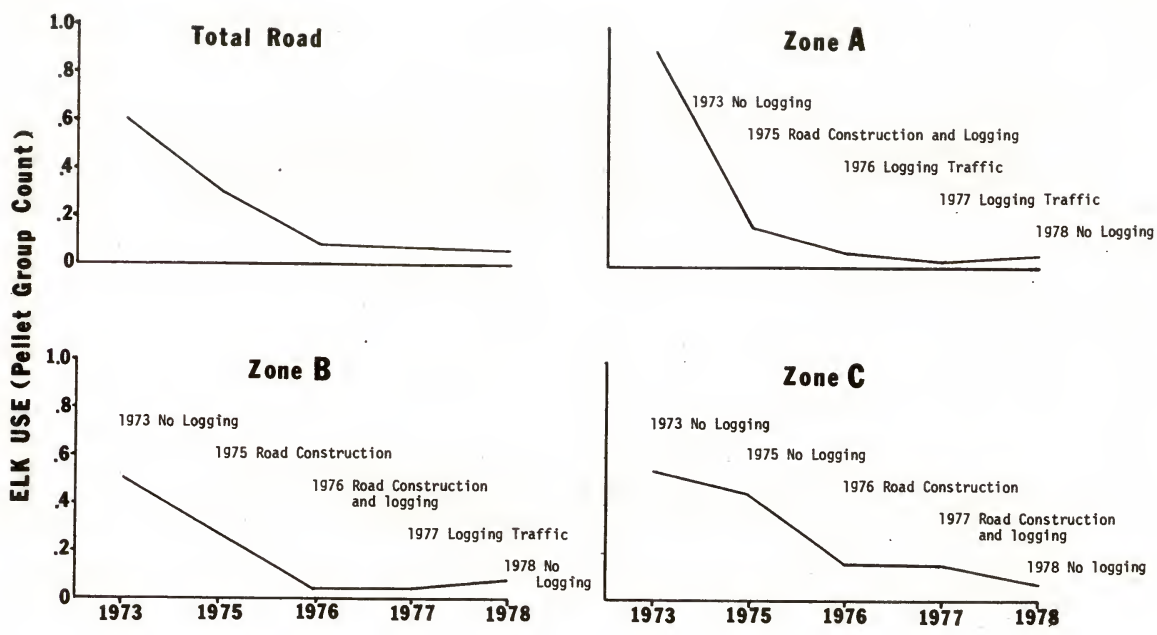

Figure 7. Fall elk use relative to the progress of the logging activity in the Long Tom Creek study area as determined by pellet group counts on cross transects perpendicular to the proposed or new logging road. 

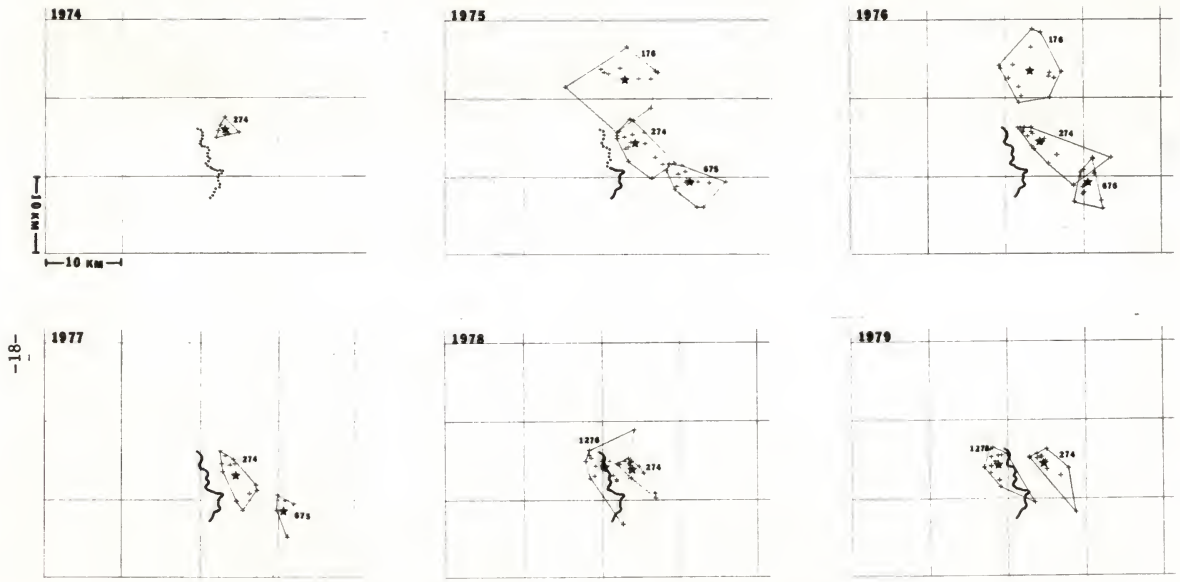

LEEEND: *-GAC, +-relocatien, $\sim$-ove logsing read

Figure 8. Comparison of summer (June 16-Sept. 30) distribution between years of tracking radio-collared elk $274,175,675$, and 1278 relative to the proposed (dotted line) or new logging road (solid 1ine). Yearly relocations are summarized by geographic activity center (GAC) and area polygon. 

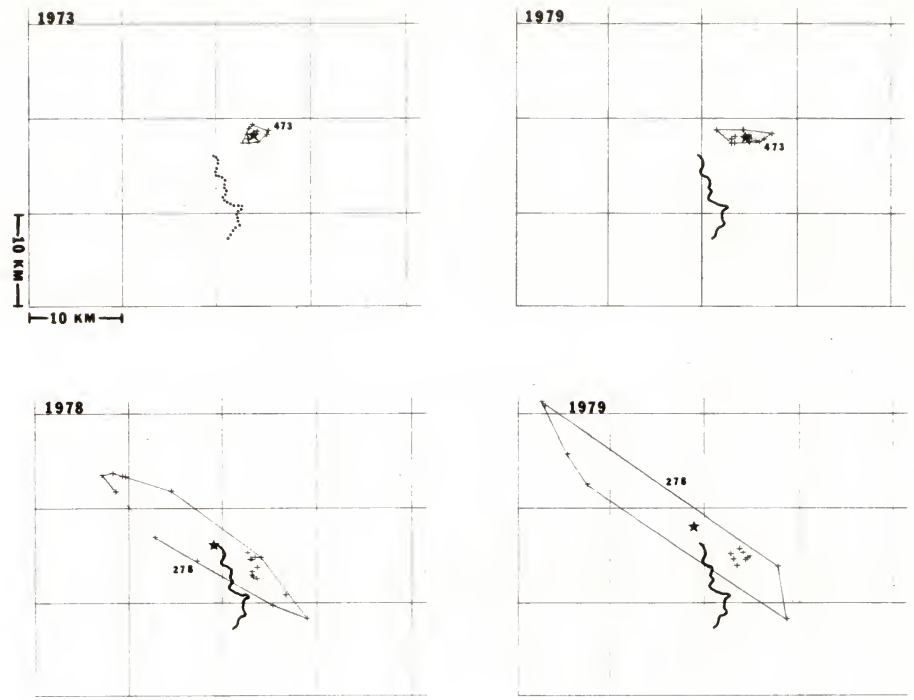

LEGEND: $*-$ GAC, +-relocation, $\sim$-new logging road

Figure 9. Comparison of summer (June 16-Sept. 30) distribution between years of trackıng radio-collared elk 473 and 278 relative to the proposed (dotted line) or new logging road (solid line). Yearly relocations are sumnarized by geographic activity center (GAC) and area polygon. 

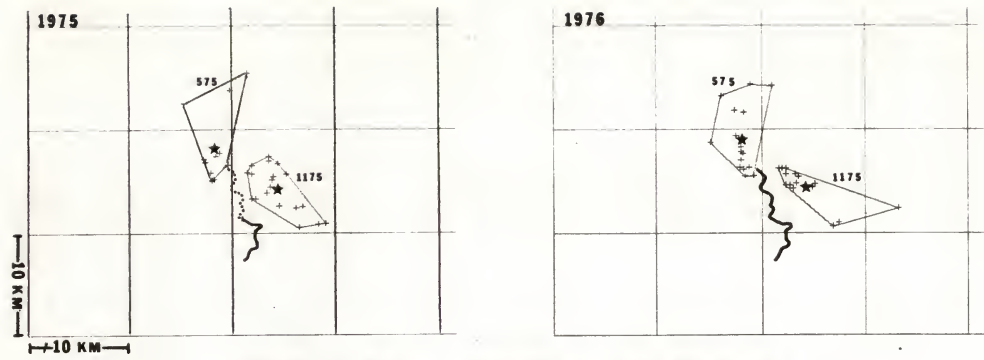

\section{LEGEND: $\star-G A C,+-$ relocation, $Z$ - new logging road}

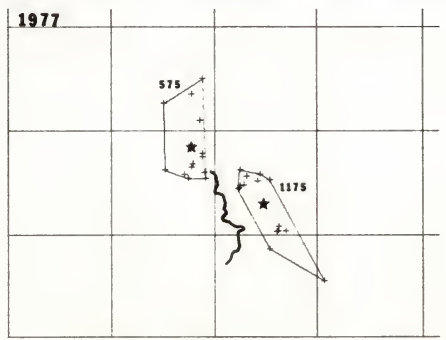

Figure 10. Comparison of summer (June 16-Sept. 30) distribution between years of tracking radio-collared elk 575 and 1175 relative to the proposed (dotted line) or new logging road (solid line). Yearly relocations are summarized by geographic activity center (GAC) and area polygon. 


\section{7}

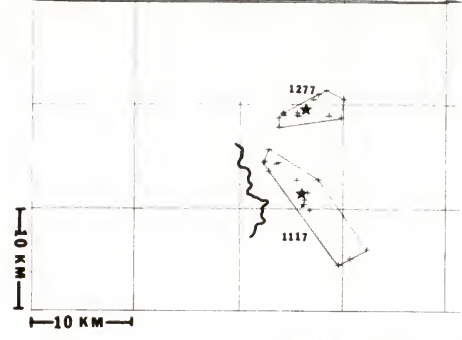

LEGEND: $\star-G A C,+-$ relocation, $Z$ - new logging road

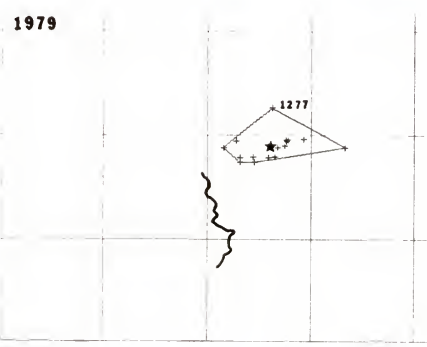

Figure 11. Comparison of summer (June 16-Sept. 30) distribution between years of tracking radio-collared elk 1277 and 1117 relative to the proposed (dotted line) or new logging road (solid line). Yearly relocations are summarized by geographic activity center (GAC) and area polygon. 
1976
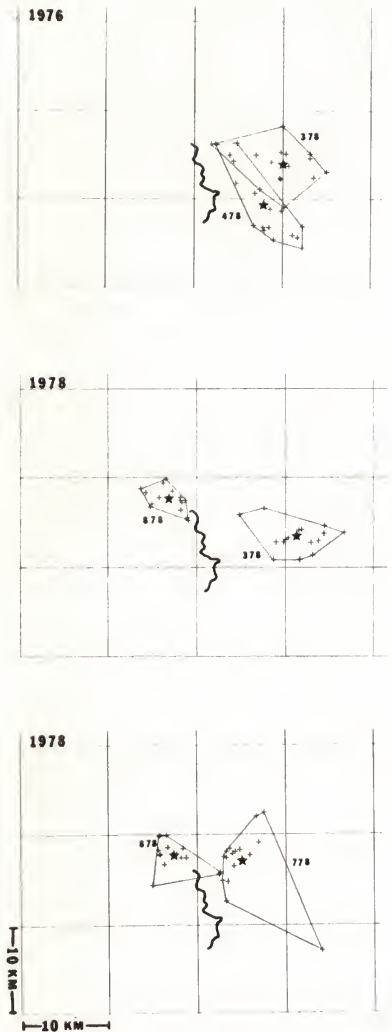

1977

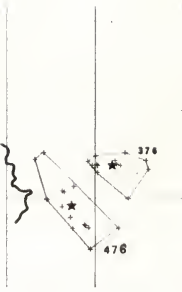

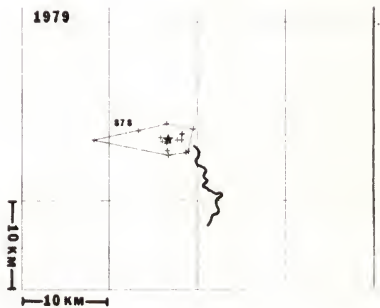

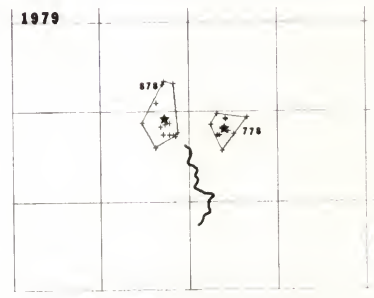

LEGEND: $\star-G A C,+-$ relocation, $z^{- \text {new logging road }}$

Figure 12. Comparison of summer (June 16-Sept. 30) distribution between years of tracking radio-collared elk $376,476,678,778$ and 878 relative to the proposed (dotted line) or new logging road (solid 1ine). Yearly relocations are summarized by geographic activity center (GAC) and area polygon. 


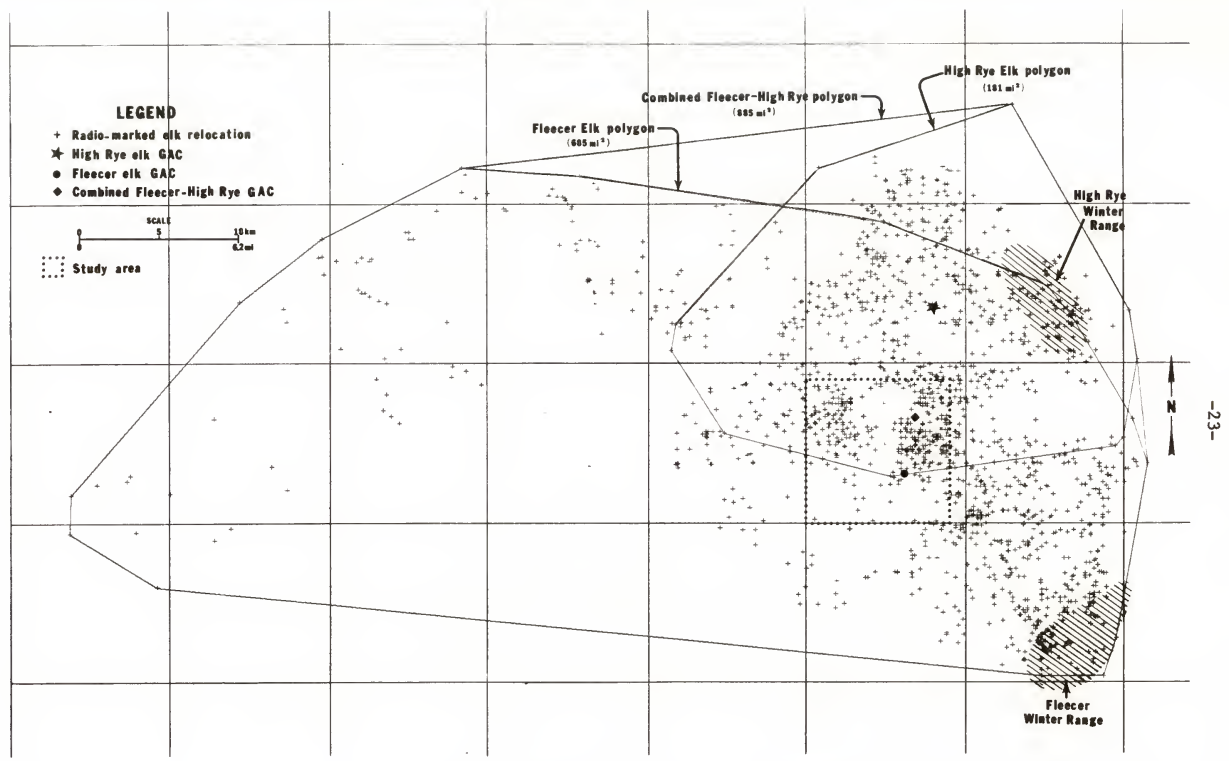

Figure 13, All relocations of radio-equipped elk determined between spring 1973 and spring 1980 in game management unit 319 with area polygons and geographic activity centers (GAC) summarizing relocations of elk from two different wintering areas. 
not as sensitive to relocations remote from the majority of activity. (One standard diameter is the diameter of a circle which has the geographic activity center (GAC) as its center with presumably at least 68 percent of the animal's activity occuring in that circle, Hayne, 1949 and Harrison, 1958.) This measurement resulted in ranges of 1.3-23.4, $1.3-14.2,1.4-10.5,1.3-12.5$ and $2.8-19.3$ miles for spring, summer, fall, winter, and spring through fall seasons, respectfully.

Triangulation results are similar to previous year's findings (Lonner, 1979) In that radio tracked elk were active and constantly on the move, but consistent to specific areas. Geographic activity centers were used to index elk use as determined by triangulation and weekly flights of 8 elk for the summer-early fall season. As shown in figures 14 and 15, these geographic activity centers for any individual radio-tracked elk were usually within 2 miles of each other. Home range polygons determined by triangulation and weekly flights also tended to show use of the same area during this time, except for elk number 278 (Fig. 14). For the past 2 years this elk has spent the spring-early summer months 12-15 miles to the northwest of the study area, but by late July moved into the study area and stayed there until late fall when movement toward the winter range occurred. Triangulation efforts recorded her location only when she was in or very close to the study area.

Bihourly relocations made during two, five and seven triangulation sessions in 1977, 1978, and 1979, respectfully have indicated the elk to be continuously active and moving. All average distances between successive relocations during a 24 hour period have been greater than a quarter mile and 58 percent were greater than a half mile with an overall average of .58 miles. A comparison of bihourly movements between four periods of the day; morning (0400-0800 hours), mid-day (0800-1600 hours), evening (1600-2200 hours) and night (2200-0400 hours) revealed activity to be highest during the morning period with a $.77 \mathrm{mile}$ average between successive relocations and least during the midday period with a .57 mile average. Evening and night averages were .59 and .63 miles respectfully (Fig. 16).

\section{Habitat Relationships}

Analysis is progressing toward measurement of habitat components of the core study area as well as management unit 319. Habitat features yet to be measured or recorded are road locations, types and densities, actual surface area and spatial arrangement of habitat and cover types and topographic relief. Once these features are documented and recorded, a comparison will be made between average occurrence of these features in the area to the measured occurrence within specified distances from areas where varying degrees of elk use has been recorded since the beginning of the study. This will provide information on what constitutes an environment elk prefer or are allowed to exist in. 

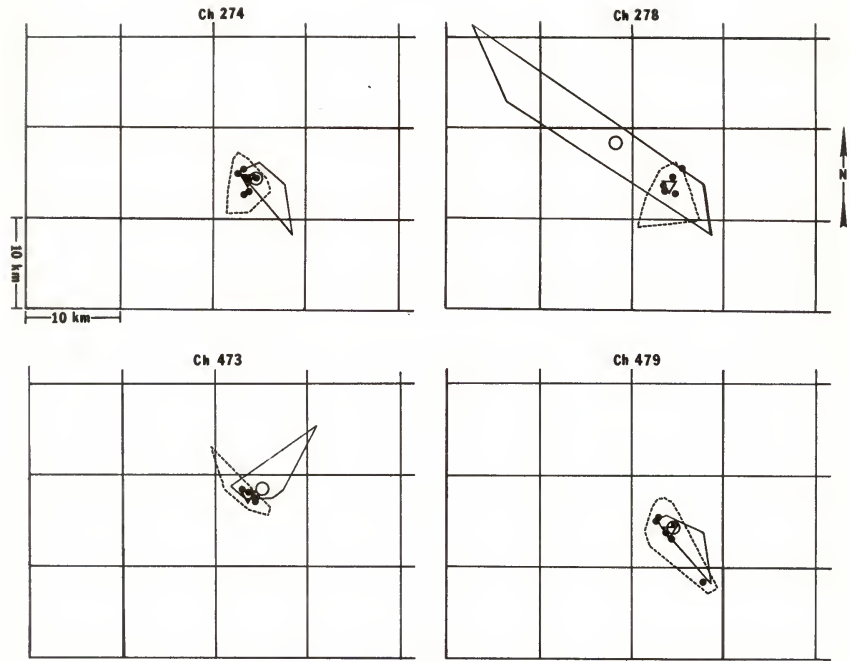

\section{LEGEND}

polygon determined by flights polygon determined by triangulation

O geographic activity center determined by flights

$\nabla$ geographic activity center determined by all triangulation sessions

- geographic activity center determined by individual triangulation sessions

Figure 14. Area polygons and geographic activity centers comparing summer-early fall distribution of radio-collared elk 274, 278, 473, and 479 as determined by ground triangulation and aerial flights in or near the Long Tom Creek study area. 

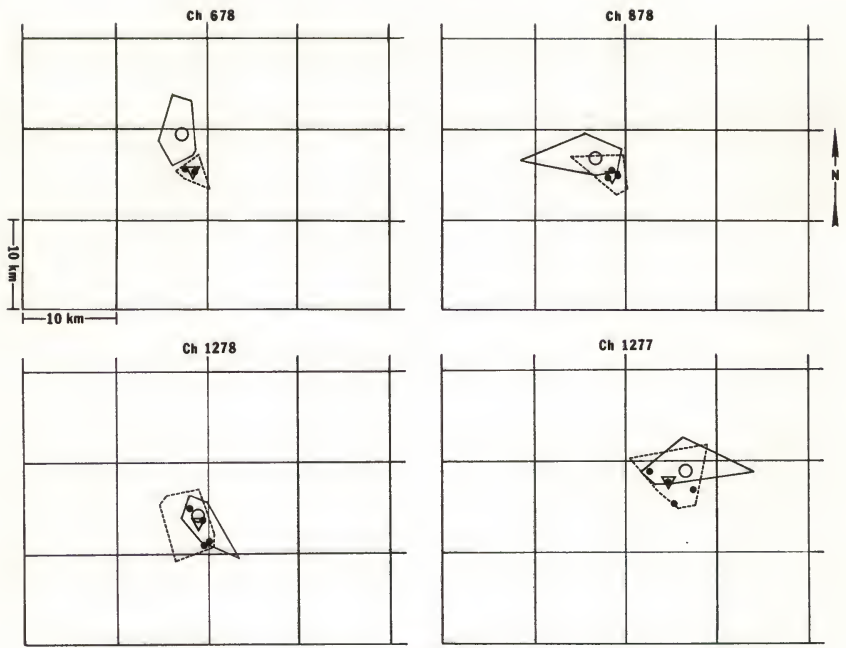

\section{LEGEND}

polygon determined by flights polygon determined by triangulation

geographic activity center determined by flights

$\nabla$ geographic activity center determined by all triangulation sessions

- geographic activity center determined by individual triangulation sessions

Figure 15. Area polygons and geographic activity centers comparing summer-early fall distribution of radio-collared elk $678,878,1278$, and 1277 as determined by ground triangulation and aerial flights in or near the Long Tom Creek study area. 


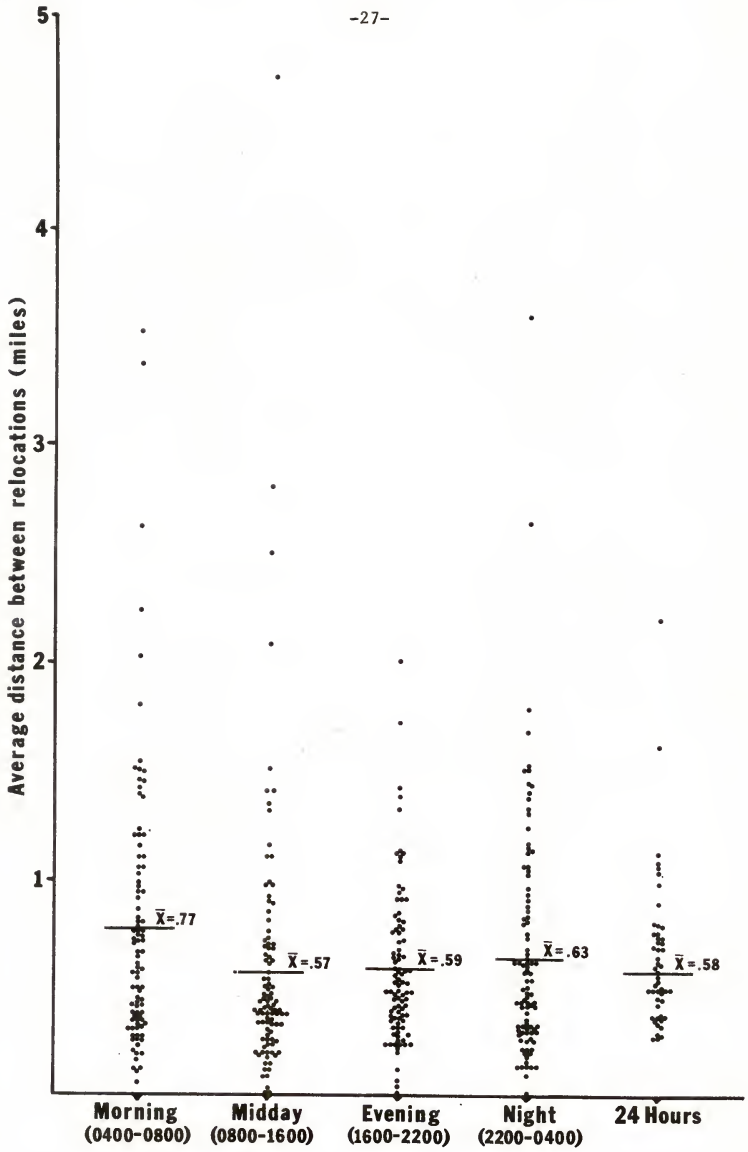

Figure 16. Average distances moved between successive bihourly relocations for a 24 hour period or portions of a day as determined by ground triangulating radio-collared $e l k$ in or near the Long Tom Creek 
In previous progress reports elk use of some general habitat and cover types has been discussed (Lonner, 1976 \& 1977). Preference for certain types and aversion to others was shown, but explanations why this occurred were speculative or lacking. Although there are many reasons why elk use the environment as they do, one of the more important reasons is probably keyed to forage production and nutrition.

In an attempt to evaluate forage characteristics as a possible influence on elk distribution and use of logged and unlogged sites within the study area, a graduate study was established during the summer of 1978 . Specific objectives were: 1) to measure and describe seasonal changes in composition, frequency and canopy coverage of plant species and net primary production and nutritional values of herbage in various vegetation types available to $\mathrm{elk}$ and 2 ) to compare clearcut and uncut sites with respect to forage production and quality. Field studies were conducted largely during the summer and fall of 1979.

The conclusions of this study follow and are excerpts from the thesis (Hammond, 1980).

The results of this study indicate the nutritional quality of both forbs and graminoids was at a seasonal high during early summer. This was evident in the high percentages of both crude protein and cell soluble material as well as the low degree of cell wall lignification of the vegetation at all 10 study sites. However, wet meadow and cutthrough dry sites were generally lower in protein than uncut dry sites and forested sites. One possible explanation for low protein values in vegetation on wet meadows is that plants grown on cold and poorly aerated solls of ten suffer from nitrogen deficiencies (Larcher, 1975). This deficiency would be manifested in low protein values. The principal reasons for higher protein values of plants on forested sites are probably tied to the repressed maturity and higher moisture content of herbages on shaded sites (Cook and Harris 1950, Campbell and Cassidy 1954, Roberts 1926). Also, forages on cut-through sites had lower moisture content than other sites during June and early July (Fig. 17). Wet meadow forbs also demonstrated high lignin concentration at this time. Except for higher lignin concentrations and lower late summer - early fall digestible energy values for forbs, this group demonstrated higher nutritional quality than graminoids throughout summer.

Since forage quality was similarly high on all sites, the quantity of available forage probably was more important than quality during early summer elk habitat selection. Thus, both uncut and cut-through dry parks and wet meadows, which represented the most species diverse and productive types avallable at this time, also recelved the greatest elk use. 


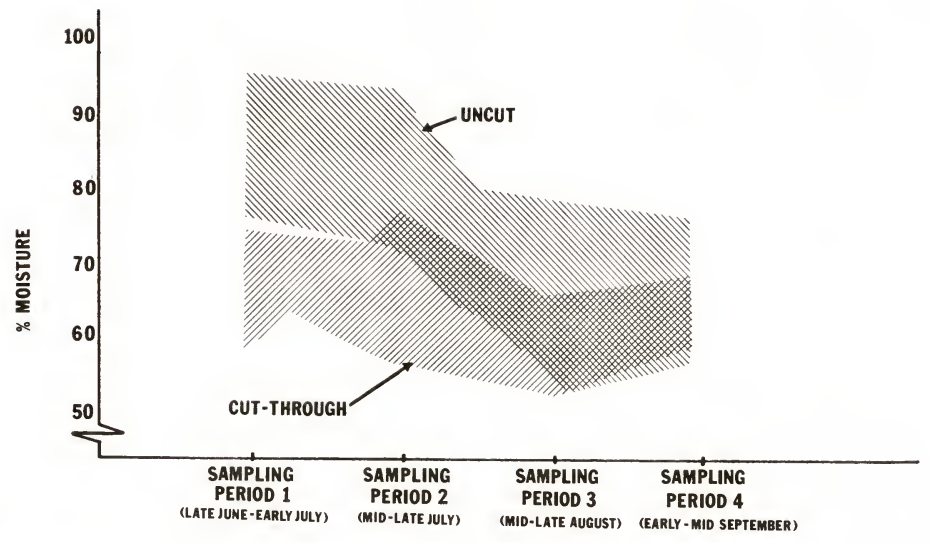

Figure 17. Range in plant moisture content by sampling period for study sites on the Long Tom Creek study area. 
The elk diet gradually shifts to succulent forages at higher elevations as phenologically-delayed species initiate rapid vegetative growth (Nelson and Leege 1979). The importance of forbs in the summer elk diet becomes apparent as this component becomes more readily available. Eustace (1967), Mackie (1970) and Stevens (1966) reported forbs comprising 67,75 and 76 percent of elk summer diets, respectively. By approximately mid July, elk are found primarily in areas where plant growth is delayed (Picton 1960, Knight 1970).

In this study, the higher nutritive value of forage species on phenologically-delayed sites was reflected in the comparatively high cell soluble material values found for forage species on both wet meadow and forested types, and high protein values on forested types. At this time, despite higher protein and cell soluble values for forbs on forested types, elk displayed a strong affinity for wet meadows. This might have been due to the higher productivity and availability of forage on wet meadows. Mautz (1971) observed that high consumption rates of plant species with lower net energy can result in a better energy balance than lower consumption of species with higher energy values. Thus, other factors, in addition to nutritional quality, were probably involved in the principal role wet meadows played in elk summer site selection.

Good nutritional quality, high forage production, high security and adequate thermal cover and a diverse species composition all contribute to the overall importance of the wet meadow type to summering elk. Hayden-Wing (1979) reported that approximately 70 percent of all forage removed by elk during the summer came from the moist cover type. Similarly, Lonner (1978) reported a strong affinity by elk for moderate wetness during the mid to late summer period. Collins et al. (1978) noted that wet meadows were hightly preferred for grazing, resting and other nongrazing activities during this same period. They further stated that elk preferred grazing areas where they could maximize intake of preferred species with a minimal expenditure of energy. During this study wet meadows were the most productive and among the most diverse sites sampled during summer (Fig. 18).

Although cut-through wet meadows were similar in most qualitative and quantitative parameters to uncut wet meadows, the reduction in security and thermal cover resulting from clearcutting may reduce the attractiveness of these sites to elk.

Partially as a result of differences in plant species composition and phenology, cut-through dry sites were generally lower than uncut dry sites in crude protein levels for forbs and graminoids, and higher in forb lignin concentrations throughout much of July and August (Fig. 19). 


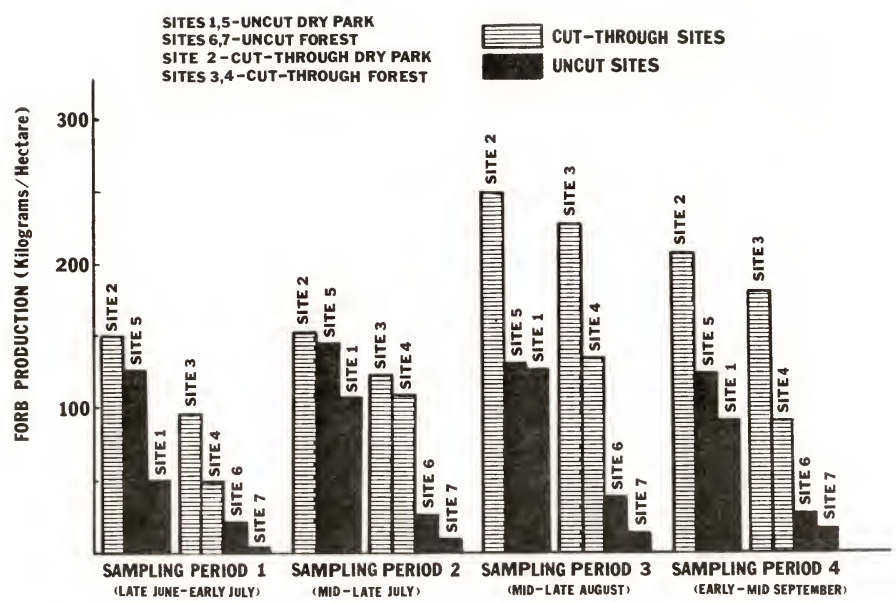

Figure 18. Forb production on uncut and cut-through sites, excluding wet meadows, on the Long Tom Creek study area. 


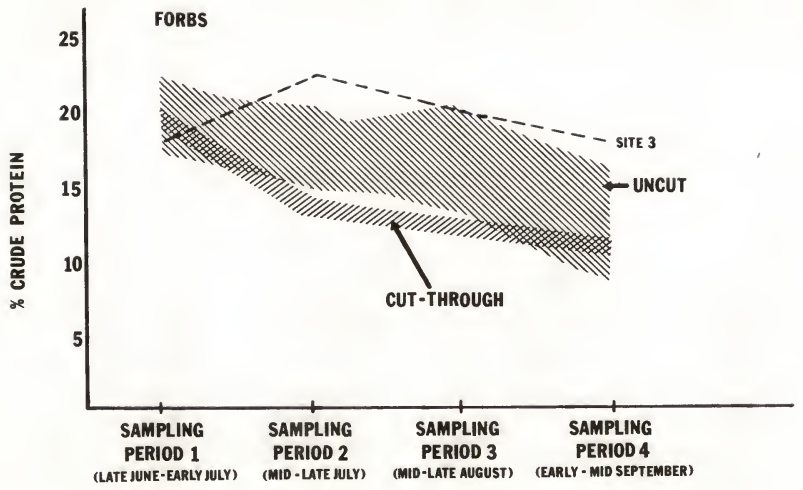

Figure 19. Range in crude protein by sampling period of forbs on study sites, and high protein values for site 3 , on the Long Tom Creek study area. 
The increased Importance assigned to the forest/dry park complex coincident with the rut and fall periods (Lonner 1978), may also be linked to, but apparently is not totally explained by forage nutrition. Forbs found on forested sites were among the highest in protein and cell-soluble contents; however, forested sites were also characterized by the lowest species diversity and productivity of all sites examined. Simultaneously, the high percentages of nonlignin cell wall constituents of grasses and sedges on dry sites contributes to high fall forage energy levels which are important to elk prior to winter.

The rather consistent decline in digestible energy in forbs through early fall is consistent with observations by Cook (1972). He stated that mature forbs commonly failed to meet the energy requirements of gestation or lactation. A low energy intake at this time would result in reduced or halted growth, welght loss, failure to conceive, increased mortality and a lowered resistance to parasites and disease (Halls 1970).

The highly nutritious but lower quantity of herbaceous forage on forested types coupled with high energy provided by dry site grasses and sedges, would enable elk to sustain a high quality diet into the fall. Moreover, forested types provide security cover during the rut and the fall hunting season.

Clearcutting did not increase the amount of dry park habitat on the study area. Additionally, dry park and forested site herbage composition and homogeneity are apparently altered by this practice.

Genera11y, forages on cut-through dry parks and cut-through forest sites were slightly lower in nutritional quality than their uncut counterparts, at least after the succulent early summer period (Figs. 17, 19, 20 and 21). During fall, the highest lignin concentrations, and lowest digestible energy values occurred for forbs on all cut-through sites, while grass and sedge protein values were lowest for the cut-through dry park site (Fig. 21).

Opening up the forest canopy by clearcutting increases forage quantity (Fig. 18). However, cattle utilization, especially on uncut and cutthrough dry parks and wet meadows, removed from 64 to 88 percent of the available herbage on these sites by fall, thereby negating many of the potential benefits resulting from increased production and diversity (Fig. 22). While the practice of clearcutting clearly benefits domestic livestock grazing operations, the disruption of existing seasonal elk range coupled with the reluctance demonstrated by elk to venture far from protective cover may effectively eliminate most potential benefits elk could derive from an increase in forage production and diversity.

The reduction in habitat diversity as a consequence of clearcut logging resulted in a trend toward lower overall nutritional quality for the mid 


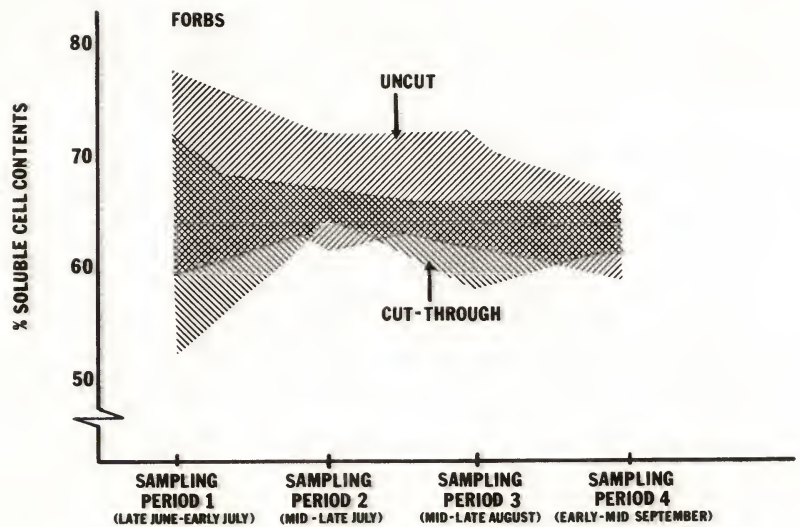

Figure 20. Range in forb cell soluble contents by sampling period for uncut and cut-through sites on the Long Tom Creek study area. 


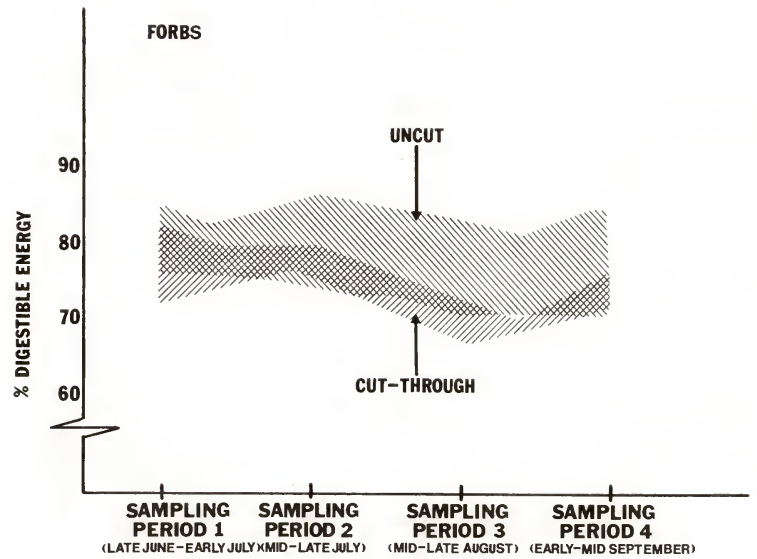

Figure 21. Range in digestible energy by sampling period of forbs on uncut and cut-through sites on the Long Tom Creek study area. 


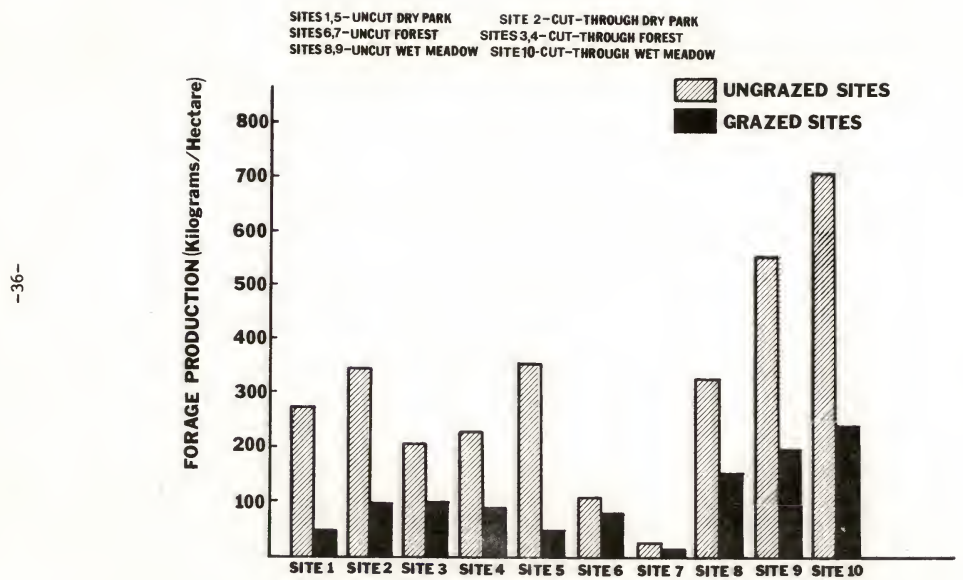

Figure 22. Standing crop of adjacent grazed and ungrazed sites at the end of the grazing season on the Long Tom Creek study area. 
summer to early fall period. This trend may potentially reduce the quality of elk habitats, especially those utilized in late summer and fa11.

\section{Literature Cited}

Campbe11, R. S. and J. T. Cassady. 1954. Moisture and protein in forage on Louisiana forest ranges. J. Range Manage. 7:41-42.

Collins, W. B., P. J. Urness, and D. D. Austin. 1978. E1k diets and activities on different Lodgepole Pine habitat segments. J. Wild1. Manage. 42(4):799-810.

Cook, C. W. 1972. Comparative nutritive values of forbs, grasses and shrubs. In: Wildland shrubs - their biology and utilization, symposium, USDA Forest Serv. General Tech. Rep. INT-1, Int. For. and Range Exp. Sta., Ogden. pp. 303-310.

and L. E. Harris. 1950. The nutritive value of range forage as affected by vegetation type, site, and stage of maturity. Utah Agr. Exp. Sta. Tech. Bu11. 344. 45 pp.

Eustace, C. D. 1967. Food habits, range use and relationships between $\mathrm{elk}$ and livestock in the Gravelly Mountains, Montana. M.S. thesis. Montana State Univ., Bozeman. 55 pp.

Halls, L. K. 1970. Nutrient requirements of livestock and game. In: Range and wildlife habitat evaluation-a research symposium, USDA Forest Serv. Misc. Pub. No. 1147. pp. 10-18.

Hammond, G. R. 1980. Nutritional characteristics of the vegetation of clearcut and uncut sites on summer-fall elk range. M.S. thesis. Montana State Univ., Bozeman. $71 \mathrm{pp}$.

Harrison, J. L. 1958. Range of Movement of some Malayan rats. J. Mamma1. 38(3):190-206.

Hayden-Wing, L. D. 1979. E1k use of mountain meadows in the Idaho Primitive Area. In: M. S. Boyce and L. D. Hayden-Wing, eds. North American E1 k: Ecology, behavior and management. Univ. Wyoming. 294 pp.

Hayne, D. W. 1949. Calculation of size of home range. J. Mamma1. $30(1): 1-18$. 
Knight, R. R. 1970. The Sun River elk herd. Wildl. Monogr. No. 23. $66 \mathrm{pp}$.

Larcher, W. 1975. Physiological plant ecology. Springer-Verlag, Berlin, Heidelberg, New York. $252 \mathrm{pp}$.

Lonner, T. N. 1976. Job II-B, Long Tom Creek Study. pp 25-72. In: Ann. Prog. Ppt. of Mont. Coop. Elk-Logging Study, 1976. 1977. Job 11-B, Long Tom Creek Study, pp 25-68.

In: Ann. Prog. Ppt. of Mont. Coop. E1k-Logging Study, 1977.

1978. Job 11-B, Long Tom Creek Study, pp 17-54.

In: Ann. Prog. Ppt. of Mont. Coop. E1k-Logging Study, 1978.

1978. Job 11-B, Long Tom Creek Study, pp 5-37.

In: Ann. Prog. Ppt. of Mont. Coop. E1k-Logging Study, 1979.

Mackie, R. J. 1970. Range ecology and relations of mule deer, elk, and cattle in the Missouri River Breaks, Montana. Wildl. Monogr. No. 20. $79 \mathrm{pp}$.

Marcum, C. L., J. F. Lehmkuhl, and M. F. Scott. 1979. Job II-D, Chamberlain Creek Study, pp 38-108. In. Ann. Prog. Ppt. of Mont. Coop. Elk-Logging Study, 1979.

Mautz, W. W. 1971. Comparison of the ${ }^{51} \mathrm{CrCl}_{3}$ ratio and total collection techniques in digestibility studies with a wild ruminant, the white-tailed deer. J. Anima1. Sci. 32(5):999-1002.

Nelson, J. R. and T. A. Leege. In press. Nutritional requirements, food habits, and diet quality of elk. Chapter - In Ecology and management of Northern American E1k. J. W. Thomas ed. Stackpole Books Inc. Harrisburg.

Pac, D. F. 1978, An Evaluation of a Fixed Nul1-Peak Tracking System for Monitoring Big Game Movements in Mountainous Terrain. In Proc. of the 1978 meeting of The Mont. Chap. of The Wildlife Society, pp. 23-32.

Picton, H. D. 1960. Migration patterns of the Sun River elk herd, Montana. J. Wild1. Manage. 24(3):279-290.

Roberts, E. W. 1926. Wyoming forage plants and their chemical composition. Studies no, 7. Effect of altitude, seasonal variation, and shading experiments. Wyo. Agric. Exp. Sta. Bull. 146:35-39.

Stevens, D. R. 1966. Range relationships of elk and livestock, Crow Creek drainage, Montana. J. Wild1. Manage. 30(2):349-363. 
JOB II-D

\section{CHAMBERLAIN CREEK STUDY}

Progress Report for the Period January 1 - December 31, 1979

\section{INTRODUCTION}

Generally, the objectives of this study are to describe elk distribution and elk use of several available environmental factors before, during and after logging in Chamberlain Creek in western Montana. The study has been conducted by personnel of the School of Forestry, University of Montana under contract to the Bureau of Land Management since 1975. Additional funding is received from the McIntire-Stennis Federal Forestry Program administered through the Montana Forest and Conservation Experiment Station, School of Forestry, University of Montana.

The contract road on the west side of Chamberlain Creek was completed during 1979. The haul road on the lower east side of Chamberlain Creek was also completed, and Burlington Northern initiated work on a spur road during early fall 1979, which projects south from the haul road into the Drainage. No logging was done within the core study area (CSA) during 1979. The BLM Chamberlain Creek Sale was let in November 1979. Road building will continue during 1980, and logging will be initiated.

Because of a request to reduce the length of the Montana Cooperative E1k-Logging Study annual reports to save on printing costs, we have abbreviated the study area description and methods sections this year. For the same reason, we will primarily present results from data collected during 1979 only. However, the discussion section will consider all results of the study to date. Data collected during previous years of this investigation are presented in the annual report for 1978 (Marcum et al. 1978 and 1979) and in Scott's thesis (1978). Complete descriptions of the study area and methods are also contained in these reports.

\section{STUDY AREA}

Location and Physiography

The study area is located in the northern Garnet Mountains of western Montana approximately 35 miles $(56 \mathrm{~km}$ ) east of Missoula (Figure 1). Radiocollared elk have used an area of approximately $72 \mathrm{mi}^{2}\left(186 \mathrm{~km}^{2}\right)$. The core study area (CSA), where logging is planned, is 5,800 acres $(2,350 \mathrm{ha})$ in size.

Elevations range from approximately 3,800 feet $(1,160 \mathrm{~m})$ along lower E1k Creek to 6,860 feet $(2,090 \mathrm{~m})$ at Chamberlain Mountain. Elevations within the CSA range from 4,400 feet $(1,340 \mathrm{~m})$ to 6,800 feet $(2,070 \mathrm{~m})$. 


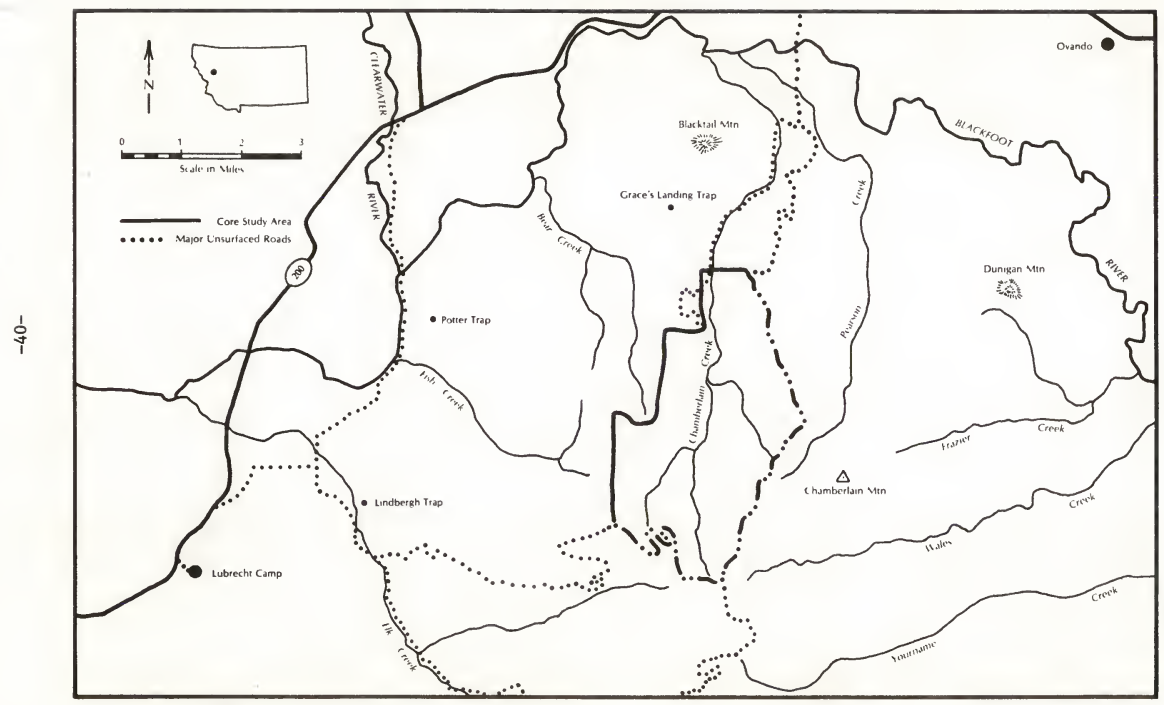

Figure 1. Map of the study area 
Land-Use Practices

Human impact on the CSA has been minimal, although most of the surrounding drainages are grazed by livestock (cattle and horses), and some of the drainages have received extensive logging. Two small clearcuts occur in the southwest corner with a larger clearcut at the northwest corner. However, the main portion of the CSA was never logged and was essentially roadless until 1978. Because of inaccessibility, only inconsequential livestock grazing occurs. The north and west boundaries of the CSA were fenced during 1977.

Extensive logging occurred throughout the study area, outside of the CSA, 40-50 years ago. Within the past 20 years, remnant and second-growth timber has been widely logged throughout Bear Creek, upper Fish Creek, Little Fish Creek, and Lower Chamberlain Creek. Generally, the logging has been some form of partial cutting, with some clearcuts in Little Fish and Bear creeks. Cattle use areas north and southwest of the CSA throughout the spring to fall seasons, whereas horses are grazed in the Fish and Bear creek drainages. Agricultural lands for hay production occur along lower Elk, Pearson, and Chamberlain creeks and on the flats between the Potter Trap and the Blackfoot River.

Recreational use is limited almost entirely to big game hunting in the fall. The study area is part of the Blackfoot Special Management Area which is closed to vehicles during the hunting season.

of the 5,800 acres $(2,350 \mathrm{ha})$ in the CSA, approximately 4,000 acres $(1,620 \mathrm{ha})$ are National Resource Lands managed by the Bureau of Land Management (BLM), and 1,800 acres ( 730 ha) are private lands (Burlington Northern, Inc.). The remainder of the general study area is, for the most part, privately owned (approximately 80 percent by Champion International Co.), with some sections owned by the State of Montana.

\section{Vegetation}

Forests of the study area are within the Douglas-fir (Pseudotsuga menziesii) and subalpine fir (Abies lasiocarpa) climax series of Pfister et al. (1977). Almost 450 sites within the study area were habitat typed by elevation and aspect to build a habitat type distribution model (Figure 2). Estimates of the proportions of different habitat types within the study area are presented with the estimates of elk use of habitat types in the telemetry results section.

Descriptions of the vegetation in the CSA, and estimates of proportions of the CSA in each type were reported by Scott (1978) and Marcum et a1. (1979). 


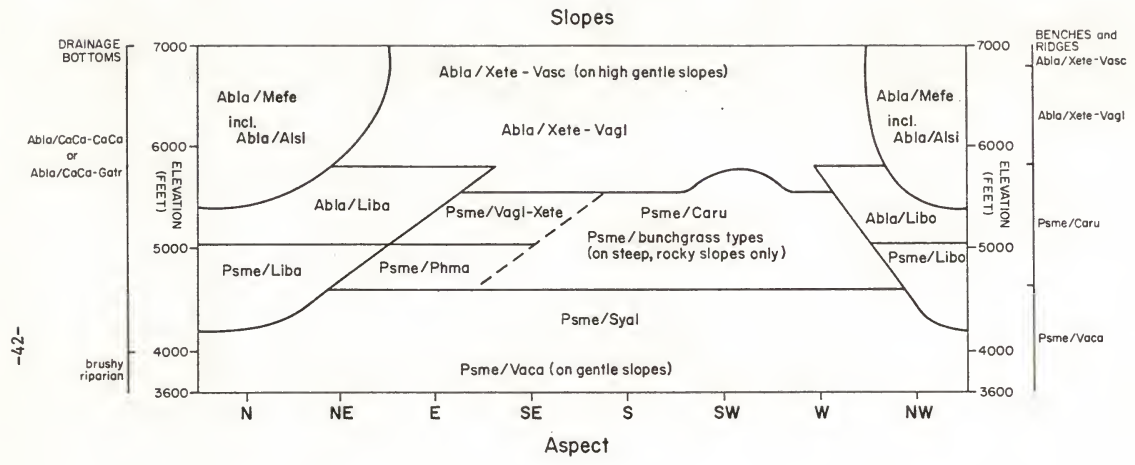

Figure 2. Habitat type distribution model

for the entire study area. 
METHODS AND MATERIALS

Habitat Description

Fifteen permanent belt transects, 4 feet $(1.2 \mathrm{~m})$ wide, were established diagonally across the core study area (CSA) at approximately one-quarter mile $(400 \mathrm{~m})$ intervals. Each transect was divided into a series of segments, not less than 50 feet $(15 \mathrm{~m})$ and not greater than one-eighth mile $(200 \mathrm{~m})$ long, according to changes in cover and/or habitat type (Pfister et al. 1977). Each segment is categorized by a variety of environmental variables. Estimates of habitat avallability in the CSA are obtained by summarizing the transect segments by the different environmental components.

To provide estimates of habitat availability for telemetry studies, an annual sample of random points within the area used by radio-collared elk is taken. Each point is described, using maps and aerial photographs, in terms of several habitat factors and disturbance relationships.

Elk Habitat Selection and Use and Distribution and Movements

Pellet counts are now conducted twice yearly, once in late June and once in late August, along transects in the CSA. Pellet groups are aged as described by Lyon (1973a), and are cleared from the transects during each count.

Weekly aerial locations of radio-collared elk are obtained from midMay through November to obtain elk habitat use and movements data, both inside the CSA and on adjacent lands. Ground telemetry is used to supplement aerial locations for determining elk movements and distribution.

Vegetative and Photo Plots

Permanent vegetation plots were established in eleven representative stands in proposed cutting units. The nested plot sampling system used was described by Lyon (1973b) and has been used in other investigations of the Montana Cooperative Elk-Logging Study. Pre-logging results were reported in August 1978 (Marcum et al. 1978). These plots will be remeasured after logging to document changes which occur. Also, representative permanent photographic plots have been established along pellet transects for preand post-logging visual reference.

\section{Statistical Procedures}

The proportion of availability of a given habitat factor, based on transect segment length or random point sampling, was compared to the proportion of elk use based on pellet counts or telemetry locations. The significance of the difference between proportions was determined by a Z-test (Snedecor and Cochran 1967). Datum analysis was accomplished using the University of Montana DECSYSTEM-20 computer and a series of standard statistical programs, Statistical Package for the Social Sciences (SPSS, Nie et a1. 1975). 
The following convention was used to indicate the statistical significance of the difference between the proportion of avallability of a habitat factor and the proportion of elk use of that factor: + or - indicates elk use significantly greater or less than avallability, $p \leq 0.05$; + or -indicates a significant difference with $\mathrm{p} \leq 0.01$; 1ack of a sign indicates no significant difference.

\section{RESULTS}

Pellet and telemetry results are not strictly comparable because of differences in technique, area and time periods considered, and sampling intensity per unit area. Therefore, these results are treated separately.

\section{Pellet Count Results}

Transects were cleared of all elk pellets during the last count of 1978. 01d and very old (OVO) pellet groups (355) counted during the first count of 1979 provided an estimate of fall 1978 elk use in the CSA. Only fresh and new (FN) pellet groups are used for spring and summer estimates of elk use. Sample sizes for spring counts are 118 during 1979, 82 during 1978 , and 139 during 1977. Summer sample sizes are 420 during 1979, 380 during 1978, 600 during 1977, and 201 during 1976.

Because of these substantial differences in sample size between counts, care must be used in interpreting the tabular data which are reported here in terms of proportions of elk use for various environmental categories. Changes in proportions within a category from one count to another do not necessarily reflect changes in the actual number of pellet groups counted for that category.

E1k distribution. The CSA was divided into 11 subunits based on topographic and vegetative homogeneity to identify yearly and seasonal shifts in elk distribution (Figure 3). Table 1 gives percentages of elk use compared to availability for CSA subunits for fall 1978, and spring and summer 1979. Figures 4 through 6 show areas of actual elk use and non-use during the same seasons. Figures 11 and 12 (Appendix I) are composite maps of the consistency of elk use in the CSA for 3 springs and 4 sumers.

Elk use in subunits 3,8 , and 9 comprised over one-half the total fal1 1978 elk use in the CSA, even though these subunits make up only $39.5 \%$ of the area. Use was significantly greater than availability in subunits 3 and 8 . Use was less than availability in the other subunits, significantly so in subunit 4 . Spring elk use occurred predominantly in the west-facing subunits 8,9 , and 10 . Use of other subunits in spring 1979 was 1 ess than avaflability. The greatest summer 1979 elk use was located primarily in subunits $3,8,9,10$ and 11 , but use was generally well distributed throughout the CSA. Relative elk use during summer months tended to increase in mesic subunits $(3,4,5,9$, and 11 ) when compared to relative use in the spring. 


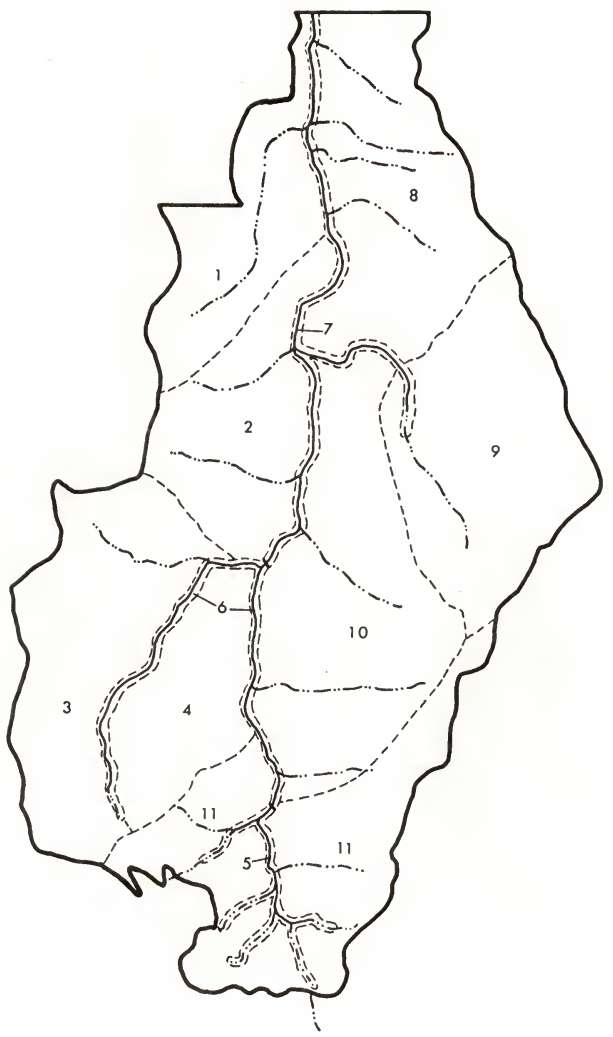

Figure 3. Map of subunits in the core study area. 


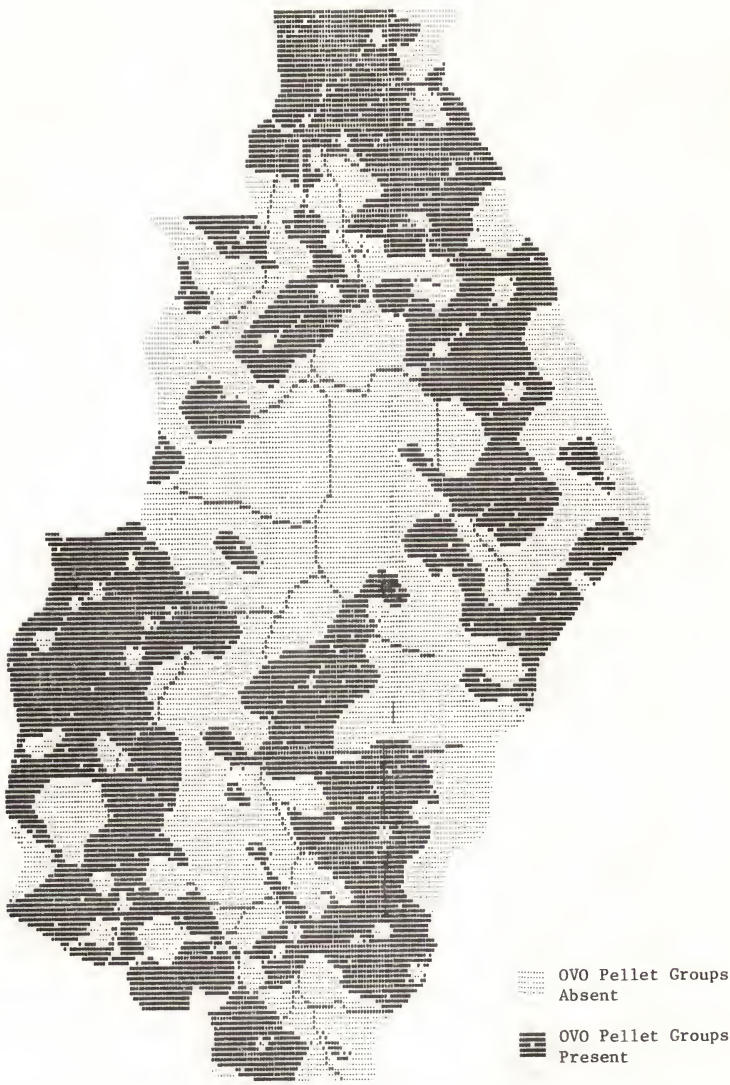

Figure 4. Areas of $\mathrm{e} 1 \mathrm{k}$ use and non-use in the CSA during fall 1978. 

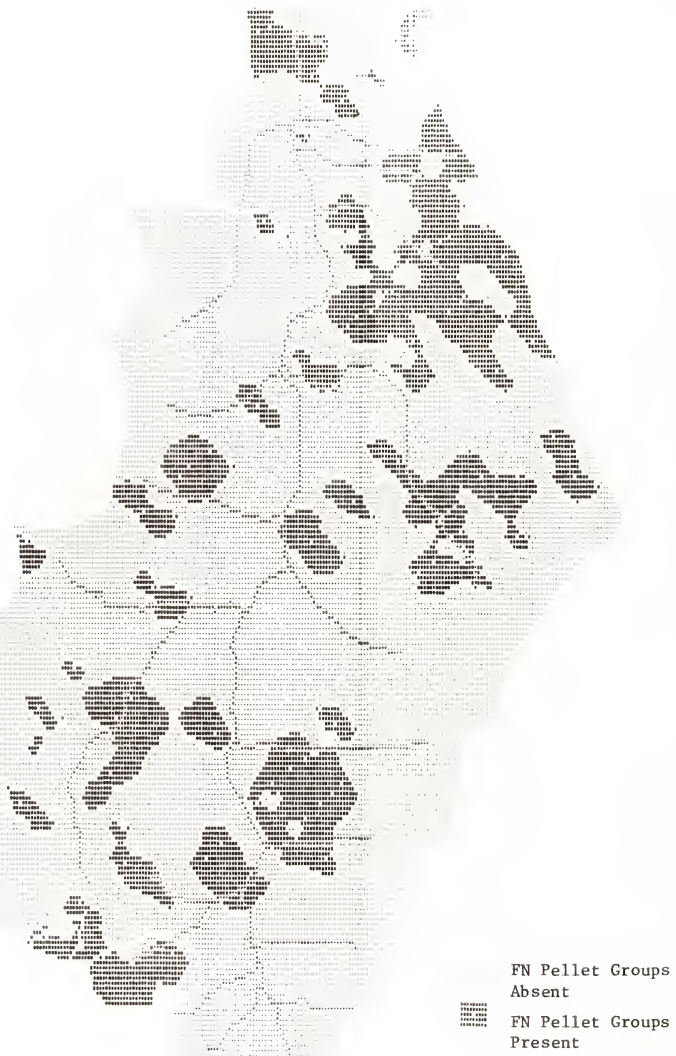

Figure 5. Areas of $\mathrm{elk}$ use and non-use in the CSA during spring 1979. 


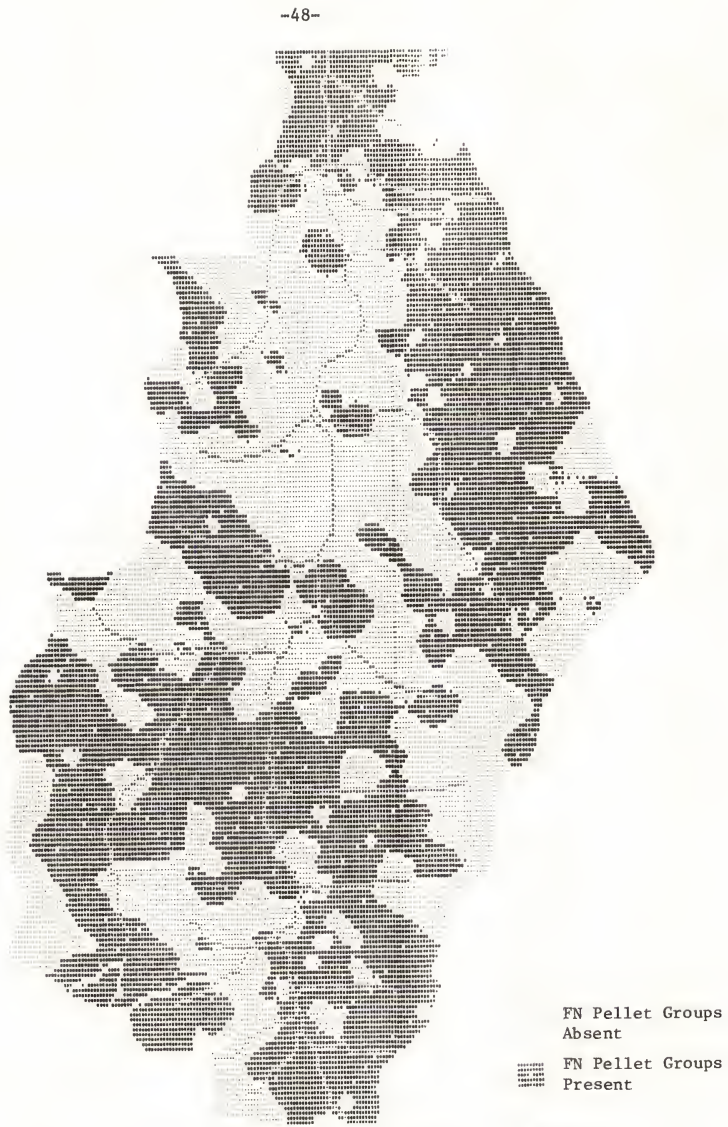

Figure 6. Areas of elk use and non-use in the CSA during summer 1979. 
Table 1. Percentages of availability and elk use related to CSA subunits.

\begin{tabular}{|c|c|c|c|c|}
\hline \multirow[b]{2}{*}{ Subunit } & \multirow[b]{2}{*}{$\begin{array}{c}\% \\
\text { Availability }\end{array}$} & Vo pellets) & \multicolumn{2}{|c|}{$\begin{array}{l}\text { \% E1k Use } \\
\text { (FN pellets) }\end{array}$} \\
\hline & & $\begin{array}{l}\text { Fa11 } \\
1978 \\
\end{array}$ & $\begin{array}{l}\text { Spring } \\
1979\end{array}$ & $\begin{array}{c}\text { Summer } \\
1979 \\
\end{array}$ \\
\hline 1 & 8.7 & 6.5 & -2.5 & 4.8 \\
\hline 2 & 9.0 & 5.4 & 5.1 & --3.6 \\
\hline 3 & 9.0 & +15.6 & 5.9 & 11.4 \\
\hline 4 & 6.4 & -2.3 & 4.2 & 5.9 \\
\hline 5 & 2.5 & 1.4 & 1.7 & 2.6 \\
\hline 6 & 3.2 & 1.1 & 2.5 & 2.9 \\
\hline 7 & 1.2 & 0.3 & 0.0 & 0.7 \\
\hline 8 & 15.6 & +24.3 & ++35.7 & ++25.2 \\
\hline 9 & 14.9 & 17.2 & 17.8 & 19.3 \\
\hline 10 & 15.8 & 13.8 & 17.0 & 11.9 \\
\hline 11 & 13.7 & 12.1 & 7.6 & 11.7 \\
\hline
\end{tabular}

Topographic factors. Tables 2 through 5 show elk use and availability by elevation, slope, aspect and topography. For all three seasons considered, elk use was greatest at $5,700-6,200$ feet $(1,740-1,890 \mathrm{~m})$, on gentle $\left(0-15^{\circ}\right)$ slopes, on westerly aspects and on mid-slopes. Elk use was significantly greater than availability during summer 1979 at the 5,700-6,200 feet $(1,740-1,890 \mathrm{~m})$ elevation interval, and during spring 1979 at mid-slopes. Use was less than availability, but not significantly so, during all three seasons at high elevations; northeast, east and south aspects; and in main streams on lower slopes, and on primary upper slopes and ridgetops.

Elk use of areas within 50 yards $(45 \mathrm{~m}$ ) of water (Table 6) was equal to or in excess of availability during all three seasons. Conversely, use was less than availability for areas greater than 450 yards $(410 \mathrm{~m})$ from water. However, none of these differences were significant.

Table 2. Percentages of availability and elk use related to CSA elevation.

\begin{tabular}{|c|c|c|c|c|}
\hline \multirow[b]{2}{*}{$\begin{array}{l}\text { Elevation } \\
\text { feet (meters) }\end{array}$} & \multirow[b]{2}{*}{$\begin{array}{c}\% \\
\text { Ayailability }\end{array}$} & \multirow{2}{*}{$\begin{array}{c}\text { (OVo Pellets) } \\
\text { Fal1 } \\
1978 \\
\end{array}$} & \multicolumn{2}{|c|}{$\begin{array}{l}\% \text { E1k Use } \\
\text { (FN Pellets) }\end{array}$} \\
\hline & & & $\begin{array}{c}\text { Spring } \\
1979 \\
\end{array}$ & $\begin{array}{c}\text { Summer } \\
1979\end{array}$ \\
\hline $\begin{array}{ll}4,500-5,000 & (1,370-1,520) \\
5,100-5,600 & (1,550-1,700) \\
5,700-6,200 & (1,740-1,890) \\
6,300-6,800 & (1,920-2,070)\end{array}$ & $\begin{array}{r}9.1 \\
22.5 \\
50.2 \\
18.2\end{array}$ & $\begin{array}{l}13.9 \\
18.9 \\
53.3 \\
13.9\end{array}$ & $\begin{array}{r}5.1 \\
27.1 \\
55.1 \\
12.7\end{array}$ & $\begin{array}{r}6.1 \\
20.7 \\
+59.1 \\
14.1\end{array}$ \\
\hline
\end{tabular}


Table 3. Percentages of availability and elk use related to CSA slope.

\begin{tabular}{|c|c|c|c|c|}
\hline \multirow[b]{3}{*}{ Slope } & \multirow[b]{3}{*}{$\begin{array}{c}\% \\
\text { Availability }\end{array}$} & \multicolumn{3}{|c|}{$\%$ Elk Use } \\
\hline & & (ovo Pellets) & & 1ets) \\
\hline & & $\begin{array}{l}\text { Fal1 } \\
1978\end{array}$ & $\begin{array}{c}\text { Spring } \\
1979\end{array}$ & $\begin{array}{c}\text { Summer } \\
1979\end{array}$ \\
\hline $0-15^{\circ}$ & 65.8 & 69.0 & 60.2 & 68.6 \\
\hline $16-30^{\circ}$ & 30.3 & 25.5 & 37.3 & 29.0 \\
\hline $31-38^{\circ}$ & 3.9 & 5.5 & 2.5 & 2.4 \\
\hline
\end{tabular}

Table 4. Percentages of availability and elk use related to CSA aspect.

\begin{tabular}{|c|c|c|c|c|}
\hline \multirow[b]{4}{*}{ Aspect } & \multirow{4}{*}{$\begin{array}{c}\% \\
\text { Availability }\end{array}$} & \multicolumn{3}{|c|}{$\%$ E1k Use } \\
\hline & & \multirow{3}{*}{$\begin{array}{c}\text { (ovo Pellets) } \\
\text { Fal1 } \\
1978\end{array}$} & \multicolumn{2}{|c|}{ (FN Pellets) } \\
\hline & & & Spring & Summer \\
\hline & & & 1979 & 1979 \\
\hline $\mathrm{N}$ & 9.2 & 9.0 & 11.9 & 10.2 \\
\hline $\mathrm{NE}$ & 20.5 & 17.5 & 12.7 & 18.6 \\
\hline E & 9.7 & 8.5 & 5.1 & 8.1 \\
\hline SE & 6.2 & 7.0 & 3.4 & 2.9 \\
\hline s & 2.3 & 1.1 & 1.7 & 0.7 \\
\hline SW & 15.2 & 16.4 & 22.9 & 18.8 \\
\hline W & 16.3 & 22.4 & 18.6 & 16.9 \\
\hline NW & 20.6 & 18.1 & 23.7 & 23.8 \\
\hline
\end{tabular}

Table 5. Percentages of availability and elk use related to CSA topography.

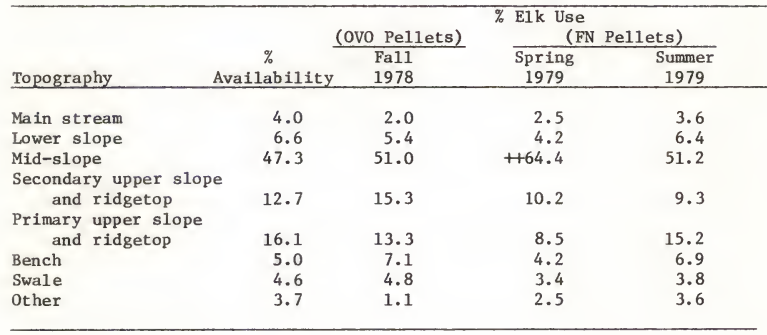


Table 6. Percentages of availability and elk use related to distance to water in the CSA.

\begin{tabular}{|c|c|c|c|c|}
\hline $\begin{array}{l}\text { Distance to Water } \\
\text { yards (meters) }\end{array}$ & $\begin{array}{c}\% \\
\text { Availability }\end{array}$ & $\begin{array}{c}\text { (OVo Pe11ets) } \\
\text { Fa11 } \\
1978\end{array}$ & $\begin{array}{r}\text { E1k Use } \\
\text { (FN } \\
\text { Spring } \\
1979\end{array}$ & $\begin{array}{c}\text { Pellets) } \\
\text { Summer } \\
1979\end{array}$ \\
\hline $\begin{array}{l}0-50 \quad(0-45) \\
50-150 \quad(45-140) \\
150-250(140-230) \\
250-350(230-320) \\
350-450(320-410) \\
450-850(410-780)\end{array}$ & $\begin{array}{r}18.3 \\
23.9 \\
21.2 \\
15.3 \\
11.6 \\
9.7\end{array}$ & $\begin{array}{r}18.9 \\
21.5 \\
28.6 \\
15.8 \\
9.3 \\
5.9\end{array}$ & $\begin{array}{r}23.7 \\
16.1 \\
21.2 \\
17.8 \\
13.6 \\
7.6\end{array}$ & $\begin{array}{r}18.3 \\
22.1 \\
26.2 \\
14.3 \\
11.2 \\
7.9\end{array}$ \\
\hline
\end{tabular}

Vegetative factors. Elk use and availability percentages for vegetative factors are presented in Tables 7 through 12. During fall 1978, elk primarily used moderately dense stands of lodgepole pine (Pinus contorta). However, use was significantly greater than availability for areas with an open overstory, and with dominant understories of bunchgrass (Festuca idahoensis -Agropyron spicatum) or mountain arnica (Arnica latifolia). Areas with a sight distance of less than 50 yards $(46 \mathrm{~m})$, a dense subalpine fir and Englemann spruce (Picea engelmanni) tree stand, a pole-sapling successional stage, and an understory dominated by grouse wortleberry (Vaccinium scoparium) were used significantly less than availability.

Table 7. Percentages of availability and elk use related to CSA overstory canopy cover.

\begin{tabular}{|c|c|c|c|c|}
\hline \multirow{4}{*}{$\begin{array}{l}\text { Overstory } \\
\text { Canopy } \\
\text { Cover }\end{array}$} & \multirow{4}{*}{$\begin{array}{c}\% \\
\text { Availability }\end{array}$} & \multicolumn{3}{|c|}{$\%$ Elk Use } \\
\hline & & (Ovo Pellets) & \multicolumn{2}{|c|}{ (FN Pellets) } \\
\hline & & Fal1 & Spring & Summer \\
\hline & & 1978 & 1979 & 1979 \\
\hline $0-25 \%$ & 5.0 & +9.4 & 5.1 & 6.9 \\
\hline $25-75 \%$ & 45.0 & 42.9 & 46.6 & 47.4 \\
\hline$>75 \%$ & 50.0 & 47.7 & 48.3 & 45.7 \\
\hline
\end{tabular}

Table 8. Percentages of availability and elk use related to CSA sight distance.

\begin{tabular}{|c|c|c|c|c|}
\hline \multirow[b]{2}{*}{$\begin{array}{l}\text { Sight Distance } \\
\text { yards (meters) }\end{array}$} & \multirow[b]{2}{*}{$\begin{array}{c}\% \\
\text { Availability }\end{array}$} & \multicolumn{3}{|c|}{$\%$ Elk Use } \\
\hline & & $\begin{array}{c}\text { Fal1 } \\
1978 \\
\end{array}$ & $\begin{array}{c}\text { Spring } \\
1979 \\
\end{array}$ & $\begin{array}{c}\text { Summer } \\
1979\end{array}$ \\
\hline $\begin{array}{l}<50(<46) \\
50-100(46-91) \\
>100(>91)\end{array}$ & $\begin{array}{r}33.1 \\
58.3 \\
8.6\end{array}$ & $\begin{array}{r}-25.1 \\
62.5 \\
12.4\end{array}$ & $\begin{array}{l}34.7 \\
48.3 \\
17.0\end{array}$ & $\begin{array}{r}29.3 \\
56.9 \\
+13.8\end{array}$ \\
\hline
\end{tabular}


Table 9. Percentages of availability and elk use related to CSA tree stand type.

\begin{tabular}{|c|c|c|c|c|}
\hline \multirow[b]{2}{*}{ Tree Stand Type } & \multirow[b]{2}{*}{$\begin{array}{c}\% \\
\text { Ava1lability }\end{array}$} & \multirow{2}{*}{$\begin{array}{c}\text { (Ovo Pellets) } \\
\text { Fal1 } \\
1978\end{array}$} & \multicolumn{2}{|c|}{$\begin{array}{l}\% \text { Elk Use } \\
\text { (FN P }\end{array}$} \\
\hline & & & $\begin{array}{c}\text { Spring } \\
1979 \\
\end{array}$ & $\begin{array}{c}\text { Summer } \\
1979 \\
\end{array}$ \\
\hline Dense PSME-LAOC & 10.8 & 11.6 & 11.9 & 12.8 \\
\hline Moderate PSME-LAOC & 9.9 & 14.5 & 8.5 & 8.3 \\
\hline Scattered 1arge PSME & 3.2 & 5.1 & 10.2 & 5.7 \\
\hline Clearing & 4.0 & 7.0 & 5.1 & 6.0 \\
\hline Dense ABLA-PIEN & 14.8 & -8.7 & 16.1 & 17.4 \\
\hline Moderate ABLA-PIEN & 5.6 & 5.1 & 2.5 & 5.5 \\
\hline Smal1 to medium PICO & 8.4 & 6.2 & 6.8 & -3.6 \\
\hline Medium to large PICO & 43.3 & 41.8 & 38.9 & 40.7 \\
\hline
\end{tabular}

PSME $=$ Pseudotsuga menzlesii

LAOC $=$ Larix occidentalis

$\mathrm{ABLA}=$ Abies lasiocarpa

PIEN $=\underline{\text { Picea }} \underline{\text { engelmanni }}$

PICO $=$ Pinus contorta

Table 10. Percentages of availability and elk use related to CSA successional stage.

\begin{tabular}{|c|c|c|c|c|}
\hline \multirow{4}{*}{$\begin{array}{l}\text { Successiona1 } \\
\text { Stage }\end{array}$} & \multirow{4}{*}{$\begin{array}{c}\% \\
\text { Availability }\end{array}$} & \multicolumn{2}{|c|}{$\%$ E1k Use } & \\
\hline & & (ovo Pellets) & \multicolumn{2}{|c|}{ (FN Pellets) } \\
\hline & & Fal1 & Spring & Summer \\
\hline & & 1978 & 1979 & 1979 \\
\hline Brush-Seedling & 1.8 & 1.7 & 2.5 & 3.3 \\
\hline Pole-Sapling & 3.3 & --0.3 & 0.0 & --0.5 \\
\hline Young Stand & 43.5 & 43.0 & 44.9 & 37.6 \\
\hline Mature Stand & 27.6 & 26.8 & 25.5 & 27.4 \\
\hline old Stand & 23.8 & 28.2 & 27.1 & 31.2 \\
\hline
\end{tabular}


Table 11. Percentages of availability and elk use related to CSA dominant understory species.

\begin{tabular}{|c|c|c|c|c|}
\hline \multirow{3}{*}{$\begin{array}{l}\text { Dominant } \\
\text { Understory }\end{array}$} & \multicolumn{4}{|c|}{$\%$ Elk Use } \\
\hline & & Pellets) & (F) & ts) \\
\hline & $\%$ & Fall & Spring & Summer \\
\hline Species & Availability* & 1978 & 1979 & 1979 \\
\hline
\end{tabular}

Festuca idahoensis-

\begin{tabular}{|c|c|c|c|c|}
\hline Agropyron spicatum & 5.8 & +11.8 & 4.2 & 4.5 \\
\hline Calamagrost is rubescens & 10.1 & 9.9 & 18.6 & 13.1 \\
\hline Arnica cordifolia & 6.6 & 6.2 & 14.4 & 10.5 \\
\hline$\overline{\text { Xerophy }} \overline{11 \text { um tenax }}$ & 35.1 & 32.4 & 28.0 & 27.9 \\
\hline Vaccinium scoparium & 17.1 & -8.5 & 5.1 & --5.7 \\
\hline Vaccinium globulare & 31.9 & 26.8 & 27.1 & 25.2 \\
\hline Menziesia ferruginea & 23.1 & 19.7 & 20.3 & 30.2 \\
\hline Alnus sinuata & 27.7 & 30.1 & 30.5 & 28.3 \\
\hline Arnica latifolia & 11.4 & ++22.5 & 14.4 & +21.2 \\
\hline Senecio triangularis & 5.2 & 6.8 & 14.4 & 8.8 \\
\hline Calamagrostis canadensis & 5.0 & 2.3 & 4.2 & 5.0 \\
\hline Other & 16.6 & 15.8 & 13.6 & 14. \\
\hline
\end{tabular}

*Since the two dominant species on each segment were recorded, the percentages total more than 100 percent.

During spring 1979 , elk use of vegetative factors was significantly different from availability in only 2 cases (Table 12). In part, this is a result of relatively small FN pellet group sample size obtained during this season. However, use was markedly greater than availability in two distinctly different types of situations. First, elk sought mature Douglasfir stands, with long sight distances (> 100 yards, $>91 \mathrm{~m}$ ), and understories dominated by pinegrass (Calamagrostis rubescens) and heartleaf arnica (Arnica cordifolia). However, elk also used more mesic areas dominated by relatively dense stands of subalpine fir and lodgepole pine, with understories dominated by mountain arnica, or arrowleaf groundsel (Senecio triangularis).

During summer 1979, elk use was significantly greater than availability on areas with long sight distances, and on areas where mountain arnica was the dominant understory plant. Use was also noticeably greater than availability in old timber stands, and in mesic subalpine fir habitat types with understories dominated by fools' huckleberry (Menziesia ferruginea) and arrowleaf groundsel. Dense pole-sapling lodgepole pine stands and areas where the understory was dominated by grouse wortleberry were used significantly less than avallability.

Response to disturbance. Disturbance within the CSA was again relatively light during seasons covered by this report. During fall 1978, the secondary haul road between BN cutting units 1 and 3 was constructed (Figure 7 ), and work continued on the main haul road. Work in both areas ceased on 19 October, just prior to the opening of the general hunting season. During spring and summer 1979 , construction of secondary haul roads in and 


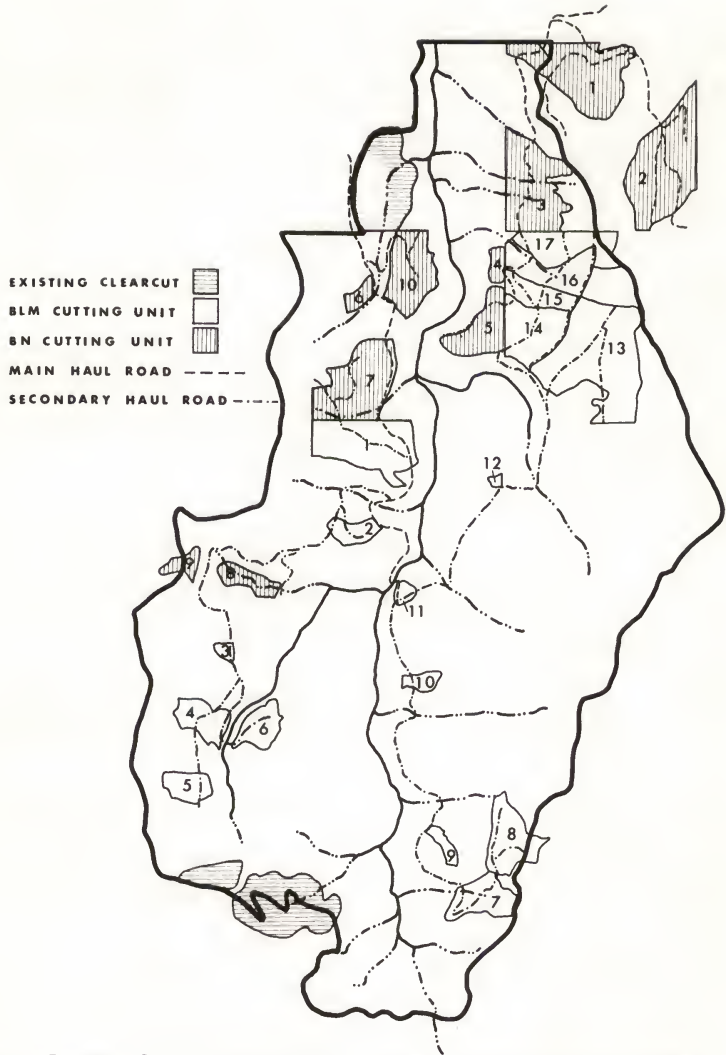

Figure 7. Map of existing clearcuts, planned cutting units, and planned roads in the CSA. 
Table 12. Percentages of availability and elk use related to CSA habitat types.

\begin{tabular}{|c|c|c|c|c|}
\hline \multirow[b]{2}{*}{ Habitat Type } & \multirow[b]{2}{*}{$\begin{array}{c}\% \\
\text { Availability }\end{array}$} & \multirow{2}{*}{$\frac{\text { (OVO Pellets) }}{\%}$} & \multicolumn{2}{|c|}{$\begin{array}{l}\text { k Use } \\
\text { (FN Pellets) }\end{array}$} \\
\hline & & & $\begin{array}{c}\text { Spring } \\
1979 \\
\end{array}$ & $\begin{array}{c}\text { Summer } \\
1979 \\
\end{array}$ \\
\hline PSME/FEID & 2.5 & 6.2 & 1.7 & 1.7 \\
\hline PSME/CARU-AGSP & 1.6 & 5.1 & 1.7 & 2.6 \\
\hline PSME/CARU ${ }^{1}$ & 4.7 & 4.5 & 5.1 & 6.4 \\
\hline PSME/PHMA ${ }^{2}$ & 0.6 & 1.1 & 0.0 & 0.7 \\
\hline PSME/VAGL-XETE ${ }^{3}$ & 1.3 & 0.6 & 6.8 & 1.4 \\
\hline PSME/LIBO ${ }^{4}$ & 1.1 & 1.1 & 0.0 & 0.0 \\
\hline $\mathrm{PSME} \mathrm{SYAL}^{5}$ & 0.9 & 1.1 & 1.7 & 1.0 \\
\hline ABLA/LIBO & 1.9 & 2.8 & 1.7 & 2.6 \\
\hline ABLA/LIBO-XETE & 14.6 & 14.8 & 18.6 & 16.0 \\
\hline ABLA/ XETE-VAGL ${ }^{6}$ & 26.0 & 18.7 & -14.4 & 17.9 \\
\hline ABLA/XETE-VASC & 5.0 & 3.9 & 1.7 & -0.7 \\
\hline ABLA/MEFE & 24.8 & 21.2 & 23.0 & 32.2 \\
\hline ABLA/ALSI & 4.0 & 4.8 & 2.5 & 2.9 \\
\hline ABLA/ CLUN $^{7}$ & 1.3 & 1.1 & 0.0 & 0.7 \\
\hline ABLA/CACA-CACA & 3.6 & 8.2 & +14.4 & 7.1 \\
\hline ABLA/CACA-GATR ${ }^{8}$ & 2.5 & 1.7 & 1.7 & 2.1 \\
\hline ABLA/CACA-VACA ${ }^{9}$ & 1.4 & 1.4 & 2.5 & 0.7 \\
\hline Clearcut & 2.0 & 1.7 & 2.5 & 3.3 \\
\hline Rock & 0.2 & 0.0 & 0.0 & 0.0 \\
\hline
\end{tabular}

${ }^{1}$ Includes ABLA/CARU

${ }^{2}$ Includes PSME/PHMA-CARU

${ }^{3}$ Includes PSME/VAGL

${ }^{4}$ Includes PSME/LIBO-SYAL, PSME/LIBO-VAGL, and PSME/LIBO-CARU

"Includes PSME/SYAL-CARU and PSME/SYAL-AGSP

${ }^{6}$ Includes ABLA/VAGL

${ }^{7}$ Includes ABLA/CLUN-ARNU and ABLA/CLUN-MEFE

${ }^{8}$ Includes ABLA/GATR

${ }^{9}$ Includes ABLA/VACA and wet meadows

near BN cuts 1,2 and 3 continued. Work on the main haul road was confined to the first 2 weeks of July. After the summer pellet count, the main haul road was completed, and the east side spur road was extended from BN cut number 3 into BN cut number 5. As in 1978, this work stopped prior to the opening of the general hunting season, and all roads were closed to vehicular access.

E1k use in disturbed subunits 1 and 2 (Table 1), where the main haul road is located, tended to be less than availability during all three seasons considered, significantly so in 2 cases. However, low use of these subunits was also recorded prior to disturbance during summer 1977 (Scott 1978 and Marcum et al. 1979). The greatest relative elk use of subunit 1 was recorded during spring 1978 when road building activities 
were most intense. Similarly, road building disturbance occurred mostly in subunit 8 during the seasons reported here, but elk use in this subunit significantly exceeded availability in all 3 cases.

Elk use within 150 yards $(140 \mathrm{~m})$ of new CSA roads was significantly less than availability during all 3 seasons (Table 13). Because much of the new road construction is in subunit 8, an area otherwise favored by elk during these seasons, it appears that elk were avolding this activity. Elk use and availability values as related to distance to proposed roads, and to proposed cutting units in the CSA are given in Tables 14 and 15 . No distinct patterns of elk use are evident with respect to either variable.

Table 13. Percentages of availability and elk use related to distance to new roads constructed within the CSA since spring 1978.

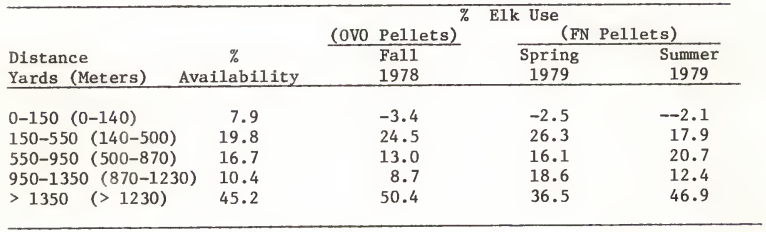

Table 14. Percentages of availability and elk use related to distance to proposed roads within the CSA.

\begin{tabular}{|c|c|c|c|c|}
\hline \multirow{4}{*}{$\begin{array}{l}\text { Distance } \\
\text { Yards (Meters) }\end{array}$} & \multirow{4}{*}{$\begin{array}{c}\% \\
\text { Availability }\end{array}$} & \multirow{2}{*}{\multicolumn{3}{|c|}{$\begin{array}{l}\% \text { Elk Use } \\
\text { (OVO Pellets) }\end{array}$}} \\
\hline & & & & \\
\hline & & Fall & Spring & Summer \\
\hline & & 1978 & 1979 & 1979 \\
\hline $0-150(0-140)$ & 28.9 & 29.9 & 31.4 & 30.4 \\
\hline $150-550(140-500)$ & 45.4 & 49.3 & 49.2 & 46.4 \\
\hline $550-950(500-870)$ & 18.2 & 14.9 & 18.6 & 19.8 \\
\hline $950-1350(870-1230)$ & 6.3 & 5.6 & --0.8 & 2.9 \\
\hline$>1350 \quad(>1230)$ & 1.2 & 0.3 & 0.0 & 0.5 \\
\hline
\end{tabular}


Table 15. Percentages of availability and elk use related to distance to proposed cutting units within the CSA.

\begin{tabular}{|c|c|c|c|c|}
\hline \multirow{4}{*}{$\begin{array}{l}\text { Distance } \\
\text { Yards (Meters) }\end{array}$} & \multirow[b]{3}{*}{$\%$} & \multicolumn{3}{|c|}{$\%$ Elk Use } \\
\hline & & \multirow{3}{*}{$\begin{array}{c}\text { (Ovo Pellets) } \\
\text { Fa11 } \\
1978\end{array}$} & \multicolumn{2}{|c|}{ (FN Pellets) } \\
\hline & & & Spring & Summer \\
\hline & Availability & & 1979 & 1979 \\
\hline $0-150(0-140)$ & 34.1 & 38.6 & 42.4 & 38.3 \\
\hline $150-550(140-500)$ & 37.5 & 35.8 & 35.6 & 36.0 \\
\hline $550-950(500-870)$ & 19.3 & 16.9 & 17.8 & 19.8 \\
\hline $950-1350(870-1230)$ & 7.5 & 5.9 & 4.2 & 5.2 \\
\hline$>1350 \quad(>1230)$ & 1.6 & 2.8 & 0.0 & 0.7 \\
\hline
\end{tabular}

Elk distribution in relation to existing clearcuts (and a seed tree cut) and roads in or near the CSA is shown in Tables 16 and 17 . These data support the previous conclusion (Scott 1978) that, under relatively low levels of human activity, distributions of elk in the CSA have not been strongly influenced by existing cuts and roads.

Table 16. Percentages of availability and elk use related to distance to existing clearcuts.

\begin{tabular}{|c|c|c|c|c|}
\hline \multirow{4}{*}{$\begin{array}{l}\text { Distance to } \\
\text { Existing } \\
\text { Clearcuts } \\
\text { Yards (Meters) } \\
\end{array}$} & & \multicolumn{3}{|c|}{$\%$ Elk Use } \\
\hline & & (Ovo Pellets) & \multicolumn{2}{|c|}{ (FN Pellets) } \\
\hline & $\%$ & Fall & Spring & Summer \\
\hline & vailability & 1978 & 1979 & 1979 \\
\hline $0-150(0-140)$ & 6.1 & 5.4 & 4.2 & 5.7 \\
\hline $150-550(140-500)$ & 11.6 & 11.5 & --4.2 & 9.1 \\
\hline $550-950(500-870)$ & 15.5 & 21.4 & 11.0 & 13.8 \\
\hline $950-1350(870-1230)$ & 15.5 & 19.7 & 16.1 & 15.2 \\
\hline$>1350 \quad(>1230)$ & 51.3 & -42.0 & +64.5 & 56.2 \\
\hline
\end{tabular}

Table 17. Percentages of availability and elk use relating to old roads in the CSA, constructed prior to spring 1978.

\begin{tabular}{|c|c|c|c|c|}
\hline \multirow{4}{*}{$\begin{array}{l}\text { Distance to } \\
\text { Road } \\
\text { Yards (Meters) }\end{array}$} & \multirow{4}{*}{$\begin{array}{c}\% \\
\text { Availability }\end{array}$} & \multicolumn{3}{|c|}{$\%$ Elk Use } \\
\hline & & \multirow{3}{*}{$\begin{array}{c}\text { (OVO Pellets) } \\
\text { Fa11 } \\
1978 \\
\end{array}$} & \multicolumn{2}{|c|}{ (FN Pellets) } \\
\hline & & & Spring & Summer \\
\hline & & & 1979 & 1979 \\
\hline $0-150(0-140)$ & 12.4 & 8.8 & 8.5 & 11.0 \\
\hline $150-550(140-500)$ & 27.4 & 27.9 & 27.1 & 25.7 \\
\hline $550-950(500-870)$ & 27.7 & 35.2 & 31.4 & 34.8 \\
\hline $950-1350(870-1230)$ & 21.6 & 19.4 & 28.8 & 21.4 \\
\hline$>1350 \quad(>1230)$ & 10.9 & 8.7 & $-4 \cdot 2$ & 7.1 \\
\hline
\end{tabular}


Future cutting units. A summary of pellet groups per 1000 steps within proposed cutting units (Figure 7) is presented in Table 18. BN cutting units were not delineated when the pellet transects were installed, so transects may extend beyond cut boundaries. Thus, results for those units are approximate. Also, four BN units were not sampled. Units 1 and 2 are outside the CSA, and units 4 and 9 are not crossed by a transect. Two other BN units ( 8 and 10 ) were only marginally sampled.

Table 18. Pellet groups per 1,000 steps in proposed CSA cutting units.

\begin{tabular}{|c|c|c|c|}
\hline & \multicolumn{3}{|c|}{ Pellet Groups per 1,000 steps } \\
\hline \multirow{3}{*}{ Cutting Unit } & Fall & Spring & Summer \\
\hline & 1978 & 1979 & 1979 \\
\hline & ovo & FN & FN \\
\hline
\end{tabular}

BLM

$\begin{array}{rrrr}1 & 0.0 & 2.3 & 1.2 \\ 2 & 3.1 & 0.0 & 6.2 \\ 3 & 20.5 & 3.4 & 3.4 \\ 4 & 4.1 & 0.8 & 6.5 \\ 5 & 0.0 & 2.8 & 8.2 \\ 6 & 7.7 & 3.9 & 13.5 \\ 7 & 6.7 & 0.0 & 3.3 \\ 8 & 2.9 & 0.0 & 4.3 \\ 9 & 0.0 & 0.0 & 0.0 \\ 10 & 3.3 & 0.0 & 3.3 \\ 11 & 0.0 & 0.0 & 0.0 \\ 12 & 0.0 & 0.0 & 0.0 \\ 13 & 4.6 & 3.4 & 14.9 \\ 14 & 8.0 & 4.0 & 5.0 \\ 15 & 2.7 & 2.7 & 29.7 \\ 16 & 0.0 & 4.3 & 21.3 \\ 17 & 6.0 & 13.1 & 20.2\end{array}$

BN

$\begin{array}{rlll}3 & 6.8 & 2.0 & 6.1 \\ 5 & 2.2 & 4.3 & 4.3 \\ 6 & 0.0 & 0.0 & 0.0 \\ 7 & 7.0 & 0.0 & 0.8 \\ 8 & 0.0 & 0.0 & 0.0 \\ 10 & 2.2 & 2.2 & 0.0\end{array}$

CORE STUDY AREA

$\begin{array}{lll}4.2 & 1.4 & 5.0 \\ 4.5 & 2.5 & 6.6 \\ 4.1 & 1.2 & 4.7\end{array}$

ALL CUTS

NON CUT

Elk use of proposed cutting units varies substantially, both seasonally and yearly (Marcum et al. 1979). However, for all three seasons considered in this report, the intensity of use on all proposed cutting units combined was greater than the intensity of elk use of areas which will not be logged. 
Elk use in the CSA related to precipitation. Precipitation during 1978- 79 was less than norma1, and intermediate to that during 1976-77, a drought year, and 1977-78 a more moist year (Figure 8). The summer 1979 pellet count was also intermediate to the 1977 and 1978 counts.

Last year we ran a number of linear regressions using the summer pellet count in the CSA and precipitation, and significant inverse relationships between precipitation and elk use were reported (Marcum et al. 1979). These relationships remain after adding the precipitation and pellet count data for 1979. However, the correlation between yearly precipitation and summer pellet counts on all transects from 1976 through 1979 declined from $r=-0.99$ to $r=-0.95$. When considering pellet counts on only the even numbered transects, we now have 5 years of data. In this case (Figure 9), the correlation between pellet count and precipitation remains very high $(r=-0.99)$.

\section{Telemetry Results}

A total of 394 aerial locations were obtained for radio-collared elk during 1979. Visual observations were made for $27 \%$ of the locations. All of the locations were used to determine elk movements and home range characteristics. Rough approximations, locations that fell far outside the study area, and bull locations were not used for analysis of habitat utilization or to determine relationships to disturbance. Consequently, the sample size for these analyses was lower than the total number of locations (Table 19).

Distribution and movements. Eight adult elk were radio-collared during the winter of 1978-1979:2 at the Grace's Landing Trap; 4 at the Lindbergh Trap; and 2 at the Potter Trap. All radio-collared elk were females, except for 1 male from the Lindbergh Trap. With the addition of 12 radio-collared elk from previous years, a total of 18 collared elk were present in the study area at the beginning of the field season. Sixteen were females; 2 were males. Fourteen radio-collared elk remained after hunting season. One transmitter package placed on a female was found broken; no signal was received for 1 female after mid-July; 1 bull could not be located after late August; and no signal was received for 1 male after early June. The latter was subsequently killed during the hunting season near Hungry Horse Reservoir, approximately 100 airline miles north of the study area. The transmitter was not working when the animal was killed.

Table 19. Number of aerial locations of radio-collared elk used for habitat utilization and disturbance relationships, and for distribution and movement statistice (in parenthesis) during 1979.

\begin{tabular}{|c|c|c|c|c|}
\hline Calving & Summer & Rut & Hunting Season & Total \\
\hline $5-15$ to $6-15$ & $6-16$ to $8-31$ & $9-1$ to $10-20$ & $10-21$ to $11-28$ & $5-15$ to $11-28$ \\
\hline $43(52)$ & $164(175)^{\mathrm{a}}$ & $91(97)$ & $63(70)$ & $361(394)$ \\
\hline
\end{tabular}

${ }^{a}$ Excludes 1 location made by chance for elk with failed transmitter. 


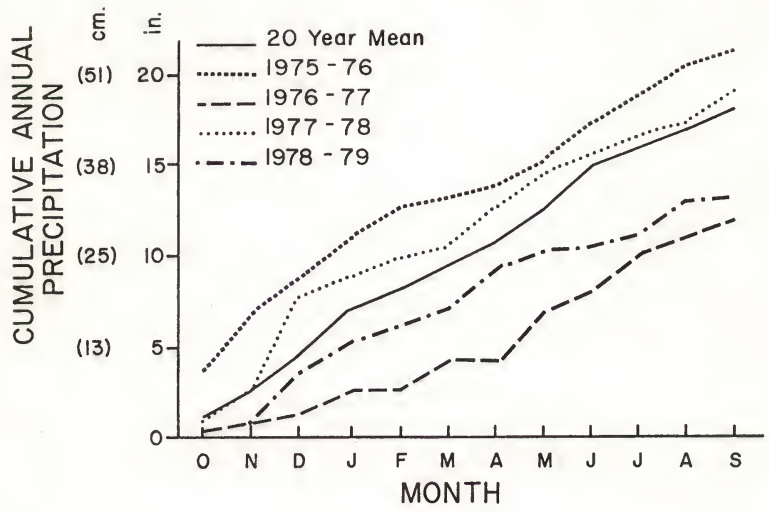

Figure 8. Cumulative annual precipitation at Lubrecht Experimenta1 Forest (Steele 1980). 


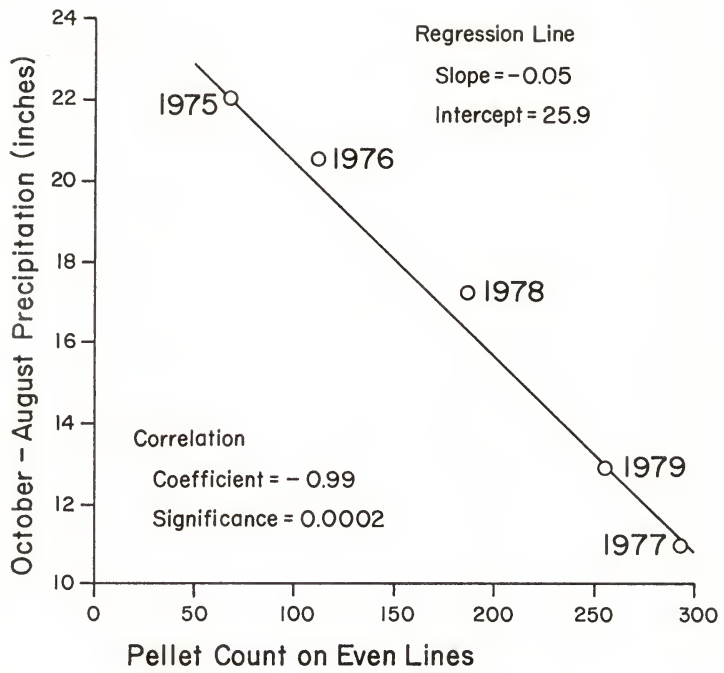

Figure 9. Linear regression of yearly summer pellet counts in the CSA against annual precipitation. 
Figures 13 through 20 show polygons which represent areas used by each radio-collared elk. Seasonal and total geographic centers of activity are also shown. (Appendix I)

Total radio-tagged elk use in the CSA was significantly in excess of availability. Thirty-three percent of all locations from May to December were in the CSA, even though it accounts for only $15 \%$ of the area used by the elk. Elk use of the CSA was also greater than availability for all seasons: the highest use occurred during the hunting season $(+41.3 \%)$, followed by calving $(32.6 \%)$, rut $(+30.8 \%)$, and summer $(+26.8 \%)$. Areas to the north, west, and east of the CSA received $27.4 \%, 34.1 \%$ and $5.3 \%$ of the total use, respectively. For these areas, use was approximately equal to availability during each season and for the entire study period. Lands west of Elk Creek, on Lubrecht Experimental Forest, and the area north of the Blackfoot River, west of the Mouth of Bear Creek, were little used.

E1k trapped at Grace's Landing were found $60 \%$ of the time north of the CSA, and $37 \%$ of the time in the CSA. Use of the CSA by elk collared at the Lindbergh and Potter traps was $26 \%$, but the bulk of locations, $57 \%$, were to the west of the CSA. Little overlap in use of the study area occurred between the two groups (Figure 10).

Table 20 provides statistics on the distribution and movements of radio-collared elk. Total distribution of the elk over the May to December tracking period covered roughly 73 miles $2\left(190 \mathrm{~km}^{2}\right)$.

The total range of Grace's Landing elk was approximately $32 \mathrm{miles}^{2}\left(83 \mathrm{~km}^{2}\right)$ : elk from the Lindbergh and Potter traps used an area of roughly $42 \mathrm{miles}^{2}\left(107 \mathrm{~km}^{2}\right)$. These values approximate the year-round home range size of both groups, since most of the winter range is included in these areas. Year-round home ranges for individual elk ranged from $7.3 \mathrm{miles}^{2}\left(19.0 \mathrm{~km}^{2}\right)$ to $20.4 \mathrm{miles}\left(53.0 \mathrm{~km}^{2}\right)$, with a mean of $13.9 \mathrm{miles}^{2}$ $\left(36.1 \mathrm{~km}^{2}\right)$. The average individual home range size for Lindbergh-Potter elk was 16.6 miles $^{2}\left(41.9 \mathrm{~km}^{2}\right)$ whereas $11.2 \mathrm{miles}\left(29.1 \mathrm{~km}^{2}\right)$ was the average for Grace's Landing elk. Seasonally, the mean home range size for all elk was greatest during the summer $\left(5.3\right.$ miles $\left.^{2} ; 13.8 \mathrm{~km}^{2}\right)$, followed by rut $\left(4.1 \mathrm{miles} ; 10.7 \mathrm{~km}^{2}\right)$, hunt $\left(3.3 \mathrm{miles}^{2} ; 8.6 \mathrm{~km}^{2}\right)$, and calving ( 1.1 miles $2 ; 2.9 \mathrm{~km}^{2}$ ). Considerable variability in seasonal home range size existed between individual elk. For example, home range size ranged from $2.7 \mathrm{miles}^{2}\left(7.0 \mathrm{~km}^{2}\right)$ to $11.6 \mathrm{miles}^{2}\left(30.2 \mathrm{~km}^{2}\right)$ during the sumer. Small sample size for seasonal ranges may be an important factor contributing to the apparent variability.

Although home range size was quite variable, mean distance moved between successive locations exhibited little variability among individua 1 elk or between trap groups. Mean values for the entire season ranged from 1.5 miles $(2.4 \mathrm{~km})$ to $2.2 \mathrm{miles}(3.5 \mathrm{~km})$, with a grand mean of 1.7 miles $(2.7 \mathrm{~km})$. Elk moved an average of 1.4 miles $(2.2 \mathrm{~km})$ during calving, 1.6 miles $(2.6 \mathrm{~km})$ during the summer, and 1.8 miles $(2.9 \mathrm{~km})$ during the rutting and hunting seasons. Between trap groups, the only major difference occurred during the hunting season, when LindberghPotter elk moved an average of $2.1 \mathrm{miles}(3.4 \mathrm{~km})$, as opposed to $1.4 \mathrm{miles}$ $(2.2 \mathrm{~km})$ moved by Grace's Landing elk. 


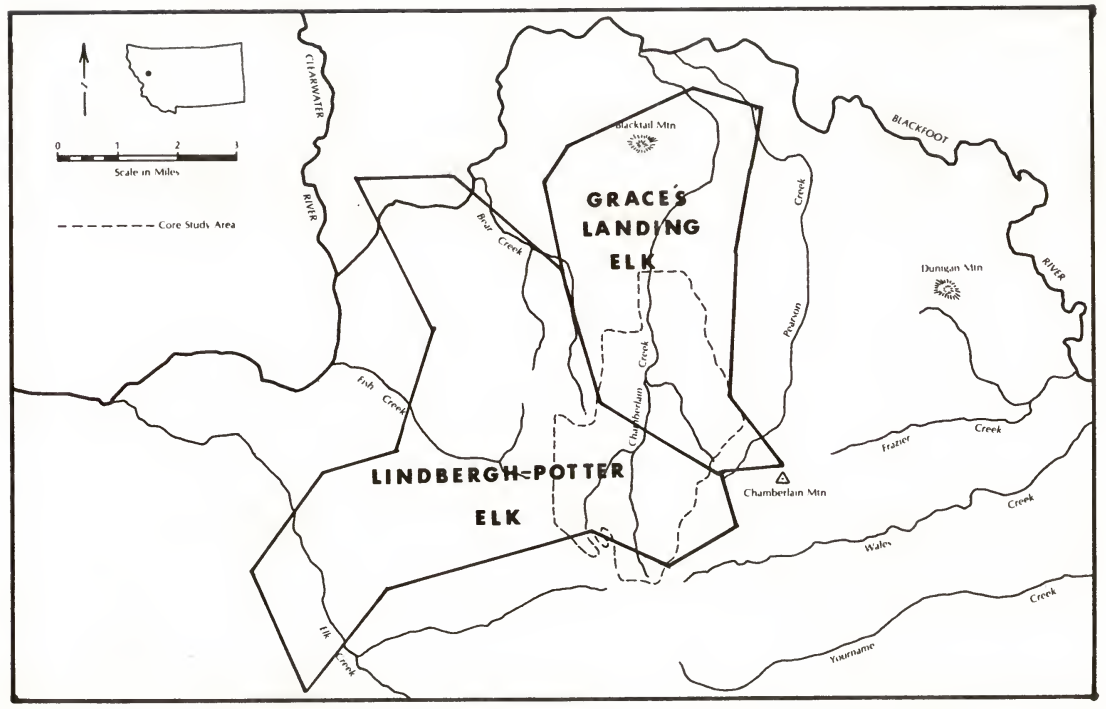

Figure 10. Primary areas used during 1979 by female radio-equipped elk, grouped by trapsite. 


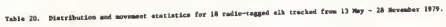

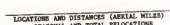

\begin{tabular}{|c|c|c|c|c|c|c|c|c|c|c|c|c|c|c|c|c|c|c|c|c|c|c|c|c|c|c|c|c|}
\hline \multirow[b]{2}{*}{ ix } & \multirow[b]{2}{*}{ seos } & \multirow[b]{2}{*}{ Jrae Hate } & \multicolumn{5}{|c|}{ 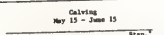 } & \multicolumn{5}{|c|}{ 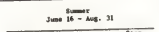 } & \multicolumn{5}{|c|}{ sopt. 1 mat - oct. 20} & \multicolumn{5}{|c|}{ 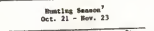 } & \multicolumn{5}{|c|}{ 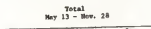 } & \multirow{2}{*}{ 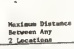 } \\
\hline & & & not & $\vec{x}$ & Anes". & Mons. & $\begin{array}{l}\operatorname{stang}^{2} \\
\text { Dia. }\end{array}$ & A. & $\pi$ & aser & max. : & tion. & A. & $\bar{x}$ & Area & max. & Stese. & m. & $\bar{x}$ & Area & max. & trow. & & 7 & Nres & $\max$ & $\begin{array}{l}\text { Stan. } \\
\text { panis. }\end{array}$ & \\
\hline 22 & 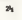 & Gresec'e Lending & 4 & 1.3 & 1.7 & 1.8 & 2.1 & 11 & 2.2 & 6.6 & 4.6 & 3.8 & , & 1.2 & 1.4 & 2.4 & 1.9 & 3 & 1.6 & 1.3 & 2.0 & 2,2 & 27 & 1.7 & $n$ & 4.6 & 3.2 & 3.4 \\
\hline 3 & hy & 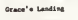 & - & 1.4 & 1.5 & 2.1 & 1.9 & 10 & 1.3 & 3.4 & 3.2 & 2.4 & T & 1.6 & 3.3 & 2.8 & 2.9 & , & 1.2 & a.s & 2.2 & 1.7 & 26 & 1.7 & 13.4 & 6.7 & 4.9 & 0.3 \\
\hline 3 & th & Greec'te Lendiles & 1 & - & - & - & - & "1 & 2.3 & 3.0 & 2.4 & 2.1 & , & 2.1 & 1.1 & 3.9 & 3.7 & s & 1.3 & 1.0 & 1.0 & 1.7 & ${ }^{24}$ & 1.3 & . - & 3.9 & - & 3.6 \\
\hline$\leftrightarrow$ & $x$ & Cracect'o Landias & 4 & 0.7 & 0.3 & 0.9 & 0.0 & n & 1.7 & 4.2 & 3.4 & 2.8 & , & 2.1 & 3.1 & 3.6 & 3.2 & 3 & 2.4 & 2.2 & 3.7 & 4.7 & 27 & 1.7 & 10.6 & 3. & 3.7 & 6.1 \\
\hline 4 & x & Grecet' Lenditas & . & 1,3 & 0.6 & 2.4 & 2.3 & 10 & 1.4 & 3.7 & 3.7 & 3.0 & , & 1.3 & 4.6 & 3.0 & A.1 & , & 0.8 & 0.2 & 1.2 & 0.9 & 26 & 1.5 & 3.3 & 9.4 & 3.7 & 6.1 \\
\hline${ }_{29}^{411}$ & * & Greec' ' Lendites & 4 & 1.4 & 0.7 & 2.7 & 2.3 & 10 & 1.2 & 3.3 & 2.3 & 2.1 & , & 2.1 & 14.1 & 6.0 & 9.0 & , & 1.1 & 1.4 & 2.3 & L. & 26 & 1.6 & 14.9 & 6.0 & 4.0 & 6.1 \\
\hline $\begin{array}{l}{ }^{2}{ }^{\prime} \\
28\end{array}$ & in & Luebertoh & . & 1.0 & 0.7 & 2.2 & 1.9 & . & 1.7 & - & - & - & 0 & - & - & - & - & 0 & - & - & - & - & 10 & - & - & - & - & - \\
\hline 20 & An & Luoborst. & 0 & - & - & - & - & u & 1.2 & 3.9 & 2.3 & 2.0 & , & 1.9 & 2.4 & 4.5 & 9.2 & , & 1.9 & 6.3 & 3.0 & 4.3 & 23 & 1.7 & - & t.3 & - & $\cdot 7.0$ \\
\hline $\begin{array}{l}202^{2} \\
2 \mathrm{II}\end{array}$ & $x_{1}$ & LSaltoerth & 2 & 2.2 & - & 2.2 & 2.2 & , & - & - & - & - & 0 & - & - & - & - & - & - & - & - & - & 9 & - & - & - & - & $\bar{x}$ \\
\hline an & 4 & Lusderergh & - & - & - & - & - & 11 & 2.2 & 6.5 & 3.8 & 4.9 & , & 1.4 & 1.2 & 2.4 & 1.9 & 3 & 1.4 & 0,9 & 3.4 & 2.6 & $\boldsymbol{n}$ & 1.8 & - & $\begin{array}{l}1.8 \\
. .9\end{array}$ & $\overline{3.9}$ & $\begin{array}{l}7.1 \\
6.9\end{array}$ \\
\hline $\begin{array}{l}n \\
33\end{array}$ & it & rotur & • & 2.9 & $4.1^{\circ}$ & 3.4 & 3.1 & 11 & 2.4 & 9.1 & 4.9 & 3.1 . & , & 43 & 0.8 & 2.9 & 4.3 & 3 & 2.3 & 1.9 & 3.1 & 3.0 & n & & $\begin{array}{l}19.4 \\
3.9\end{array}$ & 4.9 & $\begin{array}{l}3.9 \\
3.4\end{array}$ & 6.9 \\
\hline${ }^{33}$ & $x$ & LIndberst & . & 1.6 & 1.9 & 2.2 & 2.4 & 12 & 1.3 & 3.2 & 3.9 & $2.0^{\circ}$ & , & 1.7 & $\cdot 3.8$ & 4.3 & 3.9 & , & 2.7 & 6.8 & 3.9 & $\begin{array}{l}3.9 \\
2.2\end{array}$ & ${ }_{27}^{25}$ & $\begin{array}{l}1.6 \\
1.7\end{array}$ & $\begin{array}{l}\text { b. } \\
\text { u. }\end{array}$ & 6.6 & 4.2 & 8.9 \\
\hline " & n & roteter & 4 & 1.2 & 0.4 & 1.7 & 1.e & 11 & 1.7 & 3.8 & 3.2 & 3.9 & , & 2.0 & 4.2 & 6.6 & 3.1 & , & 1.s & $\begin{array}{l}1.1 \\
3.1\end{array}$ & $\begin{array}{l}2.2 . \\
3.7\end{array}$ & $\begin{array}{l}2.2 \\
3.9\end{array}$ & 26 & 2.1 & 15.2 & 3.7 & 3.9 & 7.0 \\
\hline "12 & ar & Neteer & 3 & 1.4 & 0.4 & 2.4 & 2.3 & $" 1$ & 1.6 & 4.1 & 4.0 & 2.1 & , & 2.3 & 94 & 4.3 & 4.4 & 3 & $\begin{array}{l}2.4 \\
1.6\end{array}$ & $\begin{array}{l}3.1 \\
6.6\end{array}$ & 3.0 & A. & $\boldsymbol{n}$ & 1.8 & - & s.9 & - & 0.5 \\
\hline \multirow[t]{4}{*}{4} & in & Linteryan & ? & $\overline{1.0}$ & 0.0 & $\overline{1.4}$ & $\overline{1 .}$ & 111 & $\begin{array}{l}1.8 \\
1.2\end{array}$ & $\begin{array}{r}11.6 \\
2.7\end{array}$ & $\begin{array}{l}4.1 \\
3.7\end{array}$ & $\begin{array}{l}4.6 \\
2.7\end{array}$ & ' & $\begin{array}{l}1.6 \\
1.0\end{array}$ & $\begin{array}{l}1.7 \\
1.2\end{array}$ & $\begin{array}{l}3.9 \\
1.7\end{array}$ & 2.4 & , & 2.2 & .3 & 3.0 & 4.9 & 26 & 1.6 & 20.4 & 3.9 & 3.3 &. .1 \\
\hline & stan & & 45 & & & & & & & & & & $n$ & & & & & 10 & & & & & 316 & & & & & \\
\hline & neve & & & 1,4 & 1.1 & 2.2 & 2.1 & 104 & 1.0 & s. 3 & 3.5 & 3.0 & & 1.6 & 4.1 & A. 0 & 3.6 & & 1.8 & 3.3 & 2.9 & 3.1 & & 1.9 & 13.9 & 3.2 &. .0 & $\begin{array}{l}6.0 \\
0.90\end{array}$ \\
\hline & stave & No devinties & & 0.37 & 1.15 & $0 . \infty$ & 0.57 & & 0.40 & 2.31 & 0.73 & 0.87 & & 0.31 & 9.13 & 1.47 & 1.03 & & 0.39 & 2.79 & 1.17 & 1,32 & & 0.20 & 4.53 & 1.02 & 0.63 & \\
\hline
\end{tabular}

m.t.ents

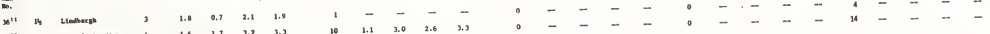

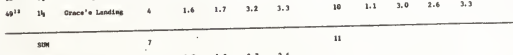

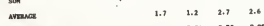

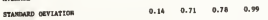

'Age set eapteres.

inder of relocationen.

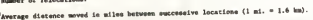

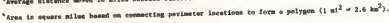

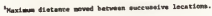

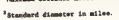

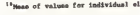

11 Hot locenced atter userly bros. 
Values for maximum distance moved between successive locations for the May to December period ranged from 3.7 miles $(5.9 \mathrm{~km})$ to $6.7 \mathrm{miles}$ $(10.7 \mathrm{~km})$, with a mean of 5.2 miles $(8.3 \mathrm{~km})$. The highest mean value was recorded for the rutting season ( 4.0 miles; $6.6 \mathrm{~km}$ ), followed by summer $(3.5$ miles: $5.6 \mathrm{~km})$, hunt $(2.9 \mathrm{miles} ; 4.6 \mathrm{~km})$, and calving $(2.2 \mathrm{miles} ; 3.5 \mathrm{~km})$. The greatest variability among individual elk occurred during the hunting season when the range was $1.2 \mathrm{miles}(1.9 \mathrm{~km})$ to 5.8 miles $(9.3 \mathrm{~km})$.

Standard diameters (Lonner 1976, after Harrison 1958) for radiocollared elk are also given in Table 20. Standard diameters for individual elk ranged from 3.3 miles $(5.3 \mathrm{~km})$ to $5.3 \mathrm{miles}(8.5 \mathrm{~km})$, with a mean of 4.9 miles $(7.8 \mathrm{~km})$, for the entire study period. Individual values varied little from the mean. Seasonally, the mean standard diameter was lowest during the calving period ( $2.1 \mathrm{miles}$; $3.4 \mathrm{~km})$. It increased during the summer $(3.0$ miles; $4.8 \mathrm{~km})$ and peaked during the rut $(3.6$ miles; $5.8 \mathrm{~km})$, then decreased during the hunting season to equal that of summer. The greatest varlability in standard diameter for individual elk occurred during the hunting season: values ranged from 0.9 miles $(1.4 \mathrm{~km})$ to 4.9 miles $(7.8 \mathrm{~km})$. In general, elk trapped at the Lindbergh and Potter traps had larger standard diameters than those elk trapped at Grace's Landing.

Twenty-one of the 54 seasonal activity centers fell within the CSA; 6 of 14 total activity centers occurred there.

Statistics for male elk are also shown in Table 20. Comparisons of statistics between male and female elk are tenuous dua to the small number of locations for males. Hopefully, more males will be radio-collared and successfully tracked in the future so that more information concerning their distribution and movements w111 be available for reliable comparisons with female elk.

Topographic factors. Within an elevational range of $3,800-6,800$ feet $(1,160-2,070 \mathrm{~m})$, the great majority of radio-collared elk were located at elevations from 4,500-6,200 feet $(1,370-1,890 \mathrm{~m})$ (Tab1e 21). Although total use was somewhat evenly distributed within this range, elk significantly preferred the 5,100-6,200 feet $(1,550-1,890 \mathrm{~m})$ interval. During the calving period, the percentage of locations was greatest in areas from 5,100-5,600 feet $(1,550-1,700 \mathrm{~m})$, and use was significantly greater than availability. By summer, elk were found within a broader range of elevations (4,500-6,200 feet; $1,370-1,890 \mathrm{~m}$ ), but they significantly preferred areas between 5,100 and 6,200 feet $(1,550-1,770 \mathrm{~m})$. Except for a decrease in use of moderately low elevations $(4,500-5,000 \mathrm{feet} ; 1,370-1,520 \mathrm{~m})$, the pattern of use did not change appreciably during the rut, from that of summer. A decrease in use of elevations below 5,600 feet $(1,700 \mathrm{~m})$ was noted during the hunting season, but areas from 5,700 to 6,200 feet $(1,740-1,890 \mathrm{~m})$ continued to be significantly preferred. The greatest use of elevations above 6,200 feet $(1,890 \mathrm{~m})$ was noted at this time. Areas below 4,400 feet $(1,340 \mathrm{~m})$ were consistent1y used significantly less than their ava1lability. 
Table 21. Percentages of availability and elk use related to study area elevation, 1979.

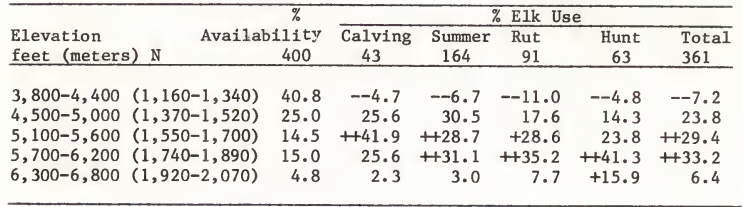

With respect to steepness of slope, elk preferred gentle (0-15 $5^{\circ}$ slopes, particularly during the hunting season (Table 22). Use of slopes steeper than $15^{\circ}$ was for the most part less than availability, but was significantly less than availability during the hunting season.

Table 22. Percentages of availability and elk use related to study area slope, 1979.

\begin{tabular}{|c|c|c|c|c|c|c|}
\hline \multirow[b]{2}{*}{ Slope } & \multirow{2}{*}{$\begin{array}{cc} & \% \\
& \text { Availability } \\
\text { N } \quad 400\end{array}$} & \multicolumn{5}{|c|}{$\%$ E1k Use } \\
\hline & & $\begin{array}{c}\text { Calving } \\
43 \\
\end{array}$ & $\begin{array}{c}\text { Summer } \\
164\end{array}$ & $\begin{array}{l}\text { Rut } \\
91\end{array}$ & $\begin{array}{c}\text { Hunt } \\
63\end{array}$ & $\begin{array}{c}\text { Total } \\
361\end{array}$ \\
\hline $\begin{array}{l}0-15^{\circ} \\
16-30^{\circ} \\
>30^{\circ}\end{array}$ & $\begin{array}{r}59.0 \\
34.0 \\
7.0\end{array}$ & $\begin{array}{r}62.8 \\
27.9 \\
9.3\end{array}$ & $\begin{array}{r}67.1 \\
27.4 \\
5.5\end{array}$ & $\begin{array}{r}65.9 \\
30.8 \\
3.3\end{array}$ & $\begin{array}{r}+84.1 \\
-15.9 \\
--0.0\end{array}$ & $\begin{array}{r}+69.3 \\
-26.3 \\
4.4\end{array}$ \\
\hline
\end{tabular}

Radioed elk generally showed little preference for aspect (Table 23). West, northwest, northeast, and east aspects were utilized the most, but only on the latter two did use significantly exceed availability for all locations. Level areas were significantly underutilized except during the rut. Use was significantly low on southwest slopes as well.

Upper slopes were preferred during every season (Table 24), significantly so except for the calving season. Conversely, lower slopes, drainage bottoms, and drainage heads were used significantly less than their occurrence. Total use of ridgetops significantly exceeded availability, and a marked preference was noted during the calving season. Along with upper slopes, mid-slope areas were significantly preferred during the summer. A finer breakdown of elk use in relation to slope position indicated that upper slopes of secondary ridges were selected for during the rut and for the entire season; whereas upper slopes of primary ridges were used about equal to their availability, except during the hunting season when use significantly exceeded availability. 
Table 23. Percentages of availability and elk use related to study area aspect, 1979.

\begin{tabular}{|c|c|c|c|c|c|c|}
\hline $\begin{array}{r}\text { Aspect } \\
\mathrm{N} \\
\end{array}$ & $\begin{array}{c}\% \\
\text { Availability } \\
400 \\
\end{array}$ & $\begin{array}{c}\text { Calving } \\
43 \\
\end{array}$ & $\begin{array}{c}\% \\
\text { Summer } \\
164\end{array}$ & $\begin{array}{c}\text { E1k } \\
\text { Rut } \\
91 \\
\end{array}$ & $\begin{array}{l}\text { Hunt } \\
63 \\
\end{array}$ & $\begin{array}{r}\text { Tota1 } \\
361 \\
\end{array}$ \\
\hline $\mathrm{N}$ & 16.8 & 18.6 & --7.3 & 9.9 & 11.1 & 10.0 \\
\hline $\mathrm{NE}$ & 9.5 & 16.3 & 16.5 & 14.3 & 19.0 & +16.3 \\
\hline E & 7.5 & 14.0 & 14.0 & 17.6 & 9.5 & +14.1 \\
\hline SE & 4.8 & 4.7 & 8.5 & 8.8 & 1.6 & 6.9 \\
\hline $\mathrm{S}$ & 2.8 & 2.3 & 5.5 & --0.0 & 3.2 & 3.3 \\
\hline SW & 9.8 & 2.3 & 5.5 & --1.1 & 3.2 & --3.6 \\
\hline W & 13.5 & 20.9 & 12.8 & 13.2 & 19.0 & 15.0 \\
\hline $\mathrm{NW}$ & 15.8 & 16.3 & 18.9 & 12.1 & 25.4 & 18.0 \\
\hline Leve1 & 19.8 & --4.7 & -11.0 & 23.1 & -7.9 & -12.7 \\
\hline
\end{tabular}

Table 24. Percentages of availability and elk use related to study area slope position, 1979.

\begin{tabular}{|c|c|c|c|c|}
\hline \multirow[b]{2}{*}{ Slope Position } & \multirow{2}{*}{$\begin{array}{c}\% \\
\text { Availability }\end{array}$} & \multicolumn{2}{|c|}{$\%$ Elk Use } & \multirow[b]{2}{*}{$\begin{array}{c}\text { Total } \\
361\end{array}$} \\
\hline & & $\begin{array}{ccc}\text { Calving } & \text { Summer } & \text { Rut } \\
43 & 164 & 91 \\
\end{array}$ & $\begin{array}{c}\text { Hunt } \\
63\end{array}$ & \\
\hline Ridge Top & 8.8 & $25.6 \quad 10.4$ & 17.5 & +15.2 \\
\hline Upper Slope & 25.0 & $39.5+37.2+42.9$ & +52.4 & +41.6 \\
\hline Mid-Slope & 21.8 & $25.6++40.2$ & 17.5 & 29.9 \\
\hline Lower Slope & 31.3 & $--7.0--9.8--15.4$ & --12.7 & --11.4 \\
\hline Drainage Bottom & 8.8 & $2.3--1.2--2.2$ & --0.0 & -1.4 \\
\hline Drainage Head & 4.5 & $1.2--0.0$ & --0.0 & --0.6 \\
\hline
\end{tabular}

With respect to horizontal configuration of the slope along the contour, straight and concave configurations were generally favored (Table 25). Convex configurations were preferred during the calving period, but were used significantly less than availability during the rutting and hunting seasons, and for the entire period. Straight and concave configurations were generally selected for during the summer and rut, but not significantly so. During the hunting season, straight configurations received the most use, followed by convex configurations.

E1k appeared to be little affected by the distribution of water and moist sites in the study area during 1979 (Table 26). Use of areas greater than 550 yards $(500 \mathrm{~m})$ from moist sites was significantly greater than availability from May to December; whereas areas within 150 yards $(140 \mathrm{~m})$ of water were generally used less than availability, except during summer when use approximately equalled avallability. 
Table 25. Percentages of availability and elk use related to horizontal configuration along the slope contour, 1979.

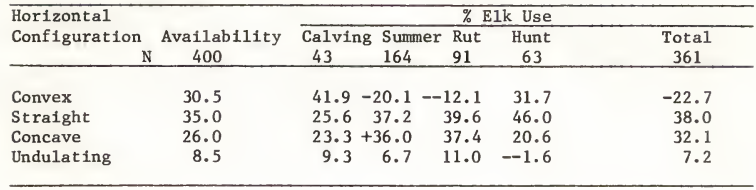

Table 26. Percentages of availability and elk use related to distance to water, 1979.

\begin{tabular}{|c|c|c|c|c|c|c|}
\hline \multirow{2}{*}{$\begin{array}{l}\text { Distance to Wate } \\
\text { yards (meters) }\end{array}$} & $\%$ & \multicolumn{5}{|c|}{$\%$ E1k Use } \\
\hline & $\begin{array}{l}\text { Availability } \\
400\end{array}$ & $\begin{array}{c}\text { Calving } \\
43\end{array}$ & $\begin{array}{c}\text { Summer } \\
164\end{array}$ & $\begin{array}{l}\text { Rut } \\
91\end{array}$ & $\begin{array}{c}\text { Hunt } \\
63\end{array}$ & $\begin{array}{l}\text { Total } \\
361\end{array}$ \\
\hline $0-50 \quad(0-45)$ & 16.0 & -4.7 & 15.9 & 14.3 & --3.2 & 11.9 \\
\hline $50-150(45-140)$ & 23.0 & --7.0 & 20.7 & -11.0 & --3.2 & --13.6 \\
\hline $150-250(140-230)$ & 24.0 & 27.9 & 24.4 & --9.9 & 22.2 & 20.8 \\
\hline $250-350(230-320)$ & 15.5 & 16.3 & 14.6 & +29.7 & 31.7 & 21.6 \\
\hline $350-450(320-410)$ & 12.5 & 20.9 & 13.4 & 18.7 & 19.0 & 16.6 \\
\hline $450-550(410-500)$ & 5.3 & 11.6 & 3.7 & 7.7 & 3.2 & 5.5 \\
\hline$>550 \quad(>500)$ & 3.8 & 11.6 & 7.3 & 8.8 & +17.5 & +10.0 \\
\hline
\end{tabular}

Vegetative factors. Dense and closed canopy coverage classes were used by elk in excess of their availability during all seasons (Table 27). Total use in both classes significantly exceeded availability. Conversely, forested areas with less than $75 \%$ canopy coverage were mainly used less than their occurrence, except during the calving season when open areas were used slightly in excess of availability.

Table 27. Percentages of avallability and elk use related to study area overstory canopy coverage, 1979.

\begin{tabular}{|c|c|c|c|c|c|c|}
\hline Overstory & & $\%$ & & $\%$ & E1k Use & \\
\hline Canopy & & Availability & Calving Summer & Rut & Hunt & Tota1 \\
\hline Cover & $\mathrm{N}$ & 400 & 164 & 91 & 63 & 361 \\
\hline OPEN & & 8.0 & $14.0--2.4$ & -2.2 & --0.0 & -3.3 \\
\hline$<25 \%$ & & 13.0 & 11.6 & --4.4 & --1.6 & 8.9 \\
\hline $25-75 \%$ & & 36.3 & 25.0 & --16.5 & --11.1 & --19.9 \\
\hline $75-95 \%$ & & 33.0 & 38.4 & +56.0 & +58.7 & +46.5 \\
\hline $95-100 \%$ & & 9.8 & $14.0++20.7$ & 20.9 & +28.6 & +21.3 \\
\hline
\end{tabular}


Elk locations were characterized by a habitat classification scheme that was developed by crosstabulating canopy coverage and successional stage, and by adding arbitrary non-forest types. With this scheme, patterns of elk use with regard to structural characteristics of timber stands were more easily determined. Table 28 gives the percentage of locations recorded in each type. Use of mature-old, mixed-species stands was primarily concentrated in dense and closed canopy types. Total use was significantly greater than avallability; seasonal use was 2-3 times greater than availability. Light-moderate canopy, pole-young, mixed-species stands were generally less preferred than dense-closed stands. For all seasons, use of the latter exceeded avallability, significantly so during the rutting and hunting seasons, and for the entire season. Use of lodgepole types approximated availability. Clearcuts were prominently used during calving. Climax and seral grass-forb areas accounted for a small portion of the study area, and were little used.

Table 28. Percentages of availabillty and elk use related to habitat age and canopy coverage, 1979.

\begin{tabular}{|c|c|c|c|c|c|c|}
\hline & $\%$ & \multicolumn{5}{|c|}{$\%$ Elk Use } \\
\hline , Canopy Cover ${ }^{\mathrm{a}} \mathrm{A}$ & $\begin{array}{l}\text { ilability } \\
300\end{array}$ & $\begin{array}{l}\text { Calving } \\
43\end{array}$ & $\begin{array}{l}\text { Summer } \\
162\end{array}$ & $\begin{array}{l}\text { r Rut } \\
91\end{array}$ & $\begin{array}{c}\text { Hunt } \\
53\end{array}$ & $\begin{array}{c}\text { Total } \\
359\end{array}$ \\
\hline Mature-01d Mixed, Light-Mod. & 2.3 & 4.7 & 1.2 & 2.2 & 0.0 & 1.7 \\
\hline Mature-01d Mixed, Dense & 4.7 & 18.6 & 12.3 & 10.0 & 9.5 & +12.0 \\
\hline Pole-Young LPP, Light-Mod. & 1.0 & 0.0 & 0.0 & 1.1 & 0.0 & 0.3 \\
\hline Pole-Young LPP, Dense & 13.7 & 4.7 & 10.5 & 15.6 & 17.5 & 12.3 \\
\hline Pole-Young Mixed, Light & 7.3 & 9.3 & 10.5 & 3.3 & -0.0 & 6.7 \\
\hline Pole-Young Mixed, Mod. & 31.3 & 18.6 & $22.8-$ & -14.4 & -11.1 & --18.2 \\
\hline Pole-Young Mixed, Dense & 23.3 & 30.2 & $35.8+$ & +52.2 & +60.3 & ++43.6 \\
\hline Brush-Seedling-Sapling & 1.3 & 0.0 & 1.9 & 0.0 & 1.6 & 1.1 \\
\hline Dry Meadow & 1.3 & 0.0 & 0.0 & 1.1 & 0.0 & 0.3 \\
\hline Wet Meadow & 0.7 & 0.0 & 0.0 & 0.0 & 0.0 & 0.0 \\
\hline Pasture-Hayfield & 6.3 & --0.0 & --0.0 & -0.0 & -0.0 & --0.0 \\
\hline North Slope Clearcut & 2.7 & 14.0 & 1.9 & 0.0 & 0.0 & 2.5 \\
\hline Road & 2.0 & 0.0 & 1.9 & 0.0 & 0.0 & 0.8 \\
\hline Other ${ }^{b}$ & 2.0 & 0.0 & 1.2 & 0.0 & 0.0 & 0.6 \\
\hline
\end{tabular}

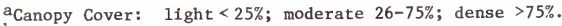

bother: brushy riparian, water, scree, rock.

Table 29 shows elk use by habitat type (Pfister et al., 1977). During the calving season, no significant preference for habitat type was noted, but the PSME/CARU type was utilized the most, with use about 3 times greater than availability. PSME/LIBO, ABLA/LIBO, and ABLA/XETE-VAGL types were also heavily used. A habitat type preference during the summer was not clearly defined. Use was well distributed among the PSME/LIBO, PSME/ CARU, ABLA/MEFE, and ABLA/XETE-VAGL types. A shift in elk use to more mesic 
habitat types was noted during the rut. ABLA/XETE-VAGL,/MEFE,/LIBO, and /CACA types received the most use, the first with use significantly greater than availability. By hunting season, the majority of elk were located in the ABLA/MEFE and/XETE-VAGL types, with use of the MEFE type significantly exceeding availability. For the total period, the percentage of locations was greatest in the ABLA/MEFE type, but, was nearly the same as the availability of that type. The ABLA/LIBO and /XETE-VAGL habitat types were used significantly greater than their availability. High use of the PSME/CARU and LIBO types was also noted. PSME/SYAL and /VACA habitat types were utilized significantly less than their occurrence.

Table 29. Percentages of availability and elk use related to study area habitat types, 1979.

\begin{tabular}{|c|c|c|c|c|c|c|}
\hline \multirow{2}{*}{$\begin{array}{l}\text { Habitat } \\
\text { Types }\end{array}$} & \multirow{2}{*}{ 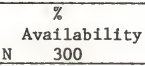 } & \multicolumn{5}{|c|}{$\%$ Elk Use } \\
\hline & & $\begin{array}{c}\text { Calving } \\
43\end{array}$ & $\begin{array}{c}\text { Summer } \\
164\end{array}$ & $\begin{array}{l}\text { Rut } \\
91\end{array}$ & $\begin{array}{l}\text { Hunt } \\
63\end{array}$ & $\begin{array}{c}\text { Total } \\
361\end{array}$ \\
\hline Dry Meadow & 1.3 & 0.0 & 0.0 & 1.1 & 0.0 & 0.3 \\
\hline Wet Meadow & 0.7 & 0.0 & 0.0 & 0.0 & 0.0 & 0.0 \\
\hline Pasture - hayfield & 6.3 & --0.0 & --0.0 & $-0.0-$ & -0.0 & -0.0 \\
\hline North Slope Clearcut & 2.7 & 14.0 & 1.8 & 0.0 & 0.0 & 2.5 \\
\hline Road & 2.0 & 0.0 & 1.8 & 0.0 & 0.0 & 0.8 \\
\hline PSME/bunchgrass & 5.7 & -0.0 & 2.4 & 1.1 & 1.6 & 1.7 \\
\hline PSME/VACA & 13.0 & --2.3 & --1.8 & $6.6-$ & -1.6 & -3.0 \\
\hline PSME/PHMA & 2.3 & 2.3 & 3.7 & 3.3 & 0.0 & 2.8 \\
\hline PSME/VAGL & 1.3 & 4.7 & 4.3 & 0.0 & 0.0 & 2.5 \\
\hline PSME/LIBE & 10.7 & 11.6 & 11.6 & 7.7 & 12.7 & 10.8 \\
\hline PSME/SYAL & 18.0 & 7.0 & 12.2 & $--5.5-$ & -4.8 & --8.6 \\
\hline PSME/CARU & 8.7 & 25.6 & 15.2 & 11.0 & 4.8 & 13.6 \\
\hline ABLA/CACA & 2.7 & 2.3 & 7.9 & 11.0 & 1.6 & 6.9 \\
\hline ABLA/LIBO & 4.3 & 14.0 & 9.8 & 12.1 & 14.3 & +11.6 \\
\hline ABLA/MEFE & 11.3 & 4.7 & 15.2 & $17.6+$ & +36.5 & 18.3 \\
\hline ABLA/XETE-VAGL & 6.7 & 11.6 & 11.0 & +22.0 & 22.2 & +15.8 \\
\hline ABLA/XETE-VASC & 0.3 & 0.0 & 0.0 & 1.1 & 0.0 & 0.3 \\
\hline Other & 1.9 & 0.0 & 1.2 & 0.0 & 0.0 & 0.6 \\
\hline
\end{tabular}

Disturbance relationships.

Distance to the nearest site of active human disturbance was recorded for each elk location. Whenever possible, distances were measured from elk locations to specific sites of human activity, such as logging and road building, as observed while tracking elk from the air. Otherwise, general areas of disturbance for discrete time periods were used. Road building activities in the study area were previously discussed in the pellet-group section. Logging occurred from late May through June on most of the westerly slopes of Blacktail Mountain, and on the lower portions of the adjacent southerly slope. From mid-July to early September, several 
small areas were logged at the head of the North Fork of E1k Creek and Cap Wallace Gulch. An area on the ridge separating the above drainages was also logged at this time. Two small areas were logged in lower Bear Creek from late August to late October. Limited logging took place from mid-October through the end of the study period in the area adjacent to, and just south of the Potter Trap. Extensive logging took place throughout the study period in areas to the east of the study area, mainly in the Pearson Creek drainage and along the River Junction Road east of Pearson Creek. In addition, small pre-commercial thinning operations took place in the large clearcuts in Little Fish Creek from mid-May through August, and in a small area southwest of the Grace's Landing Trap, at the west end of the West Fork Chamberlain Creek drainage, during late May.

For analysis purposes, locations that were closer to an open road with heavy traffic, than to a disturbance site, were eliminated. Table 30 shows the relationship between elk use and distance to disturbance. Elk significantly avoided areas within 0.5 miles $(0.8 \mathrm{~km})$ during the summer and rutting seasons, and use significantly exceeded availability in areas greater than 2.0 miles $(3.2 \mathrm{~km})$ from disturbance during the rut. An even greater negative response was noted during the summer. Elk significantly avoided areas that were less than $1.0 \mathrm{mile}(1.6 \mathrm{~km})$ from disturbance, and significantly selected areas greater than 2.0 miles $(3.2 \mathrm{~km})$ from disturbance. Areas at intermediate distances were used about equal to their occurrence. A finer breakdown of distances into $\frac{1}{4}$ mile intervals revealed similar results.

Table 30. Percentages of avallability and elk use related to logging and road building activities in the study area, 1979.

\begin{tabular}{|c|c|c|c|c|c|c|}
\hline \multirow{2}{*}{$\begin{array}{l}\text { Distance } \\
\text { to Activity } \\
\text { in Miles }\end{array}$} & \multicolumn{2}{|c|}{ Calving } & \multicolumn{2}{|c|}{ Summer } & \multicolumn{2}{|c|}{ Rut } \\
\hline & $\begin{array}{l}\text { Avail. } \\
210 \\
\end{array}$ & $\begin{array}{l}\text { Use } \\
42 \\
\end{array}$ & $\begin{array}{l}\text { Avail. } \\
110 \\
\end{array}$ & $\begin{array}{l}\text { Use } \\
150 \\
\end{array}$ & $\begin{array}{l}\text { Avai1. } \\
176 \\
\end{array}$ & $\begin{array}{l}\text { Use } \\
51 \\
\end{array}$ \\
\hline $0.0-0.5$ & 15.7 & -4.8 & 37.3 & --2.0 & 35.8 & --5.3 \\
\hline $0.5-1.0$ & 17.6 & 19.0 & 21.8 & -8.0 & 23.3 & 40.4 \\
\hline $1.0-1.5$ & 12.4 & 9.5 & 26.4 & 24.0 & 25.0 & 24.6 \\
\hline $1.5-2.0$ & 21.0 & 35.7 & 13.6 & 18.7 & 14.8 & 14.0 \\
\hline$>2.0$ & 33.3 & 31.0 & $0.9+$ & +43.3 & 1.1 & +15.8 \\
\hline
\end{tabular}

The distance to new roads in the CSA was also measured from each location (Table 31). There was a non-significant trend to higher use of areas greater than 550 yards $(500 \mathrm{~m})$ from new roads, than for areas less than 550 yards $(500 \mathrm{~m})$. Notably, there was no selection for areas on the opposite side of $3 \mathrm{rd}$ and $4 \mathrm{th}$ order ridges from new roads, many of which were being worked on during the study period. This trend was consistent during the summer, rut and hunt; but during the calving season high use was recorded at distances 150-550 yards (140-500 m) from new roads. 
Table 31. Percentages of availability and elk use related to distance to new roads in the CSA, 1979.

\begin{tabular}{|c|c|c|c|c|c|c|}
\hline \multirow{3}{*}{$\begin{array}{l}\text { Distance } \\
\text { to New Road } \\
\text { in yards (meters)N }\end{array}$} & \multirow{3}{*}{$\begin{array}{c}\% \\
\text { Availability } \\
300 \\
\end{array}$} & \multicolumn{5}{|c|}{$\%$ Elk Use } \\
\hline & & Calving & Summer & Rut & Hunt & Total \\
\hline & & 43 & 164 & 91 & 63 & 361 \\
\hline $0-150(0-140)$ & 1.7 & 0.0 & 1.2 & 3.3 & 0.0 & 1.4 \\
\hline $150-550(140-500)$ & 5.3 & 16.3 & 3.0 & 3.3 & 3.2 & 4.7 \\
\hline $550-950(500-870)$ & 3.7 & 14.0 & 7.9 & 4.4 & 6.3 & 7.5 \\
\hline $950-1350(870-1230)$ & 3.3 & 9.3 & 6.7 & 9.9 & 4.8 & 7.5 \\
\hline$>1350(>1230)$ & 19.7 & 11.6 & 28.0 & 20.9 & 30.2 & 24.7 \\
\hline Out of Range $\mathrm{e}^{\mathrm{a}}$ & 66.3 & 48.8 & -53.0 & 58.2 & 55.6 & --54.3 \\
\hline
\end{tabular}

a Out of Range: locations on opposite side of major ridge from new roads.

Vehicular use of the study area was light (less than 1 vehicle trip/day) to moderate (1-4 vehicle trips/day) during 1979. Heavy traffic (5-9 vehicle trips/day) occurred on the lower portions of the main Chamberlain Creek Road during the calving and hunting seasons. During the rut, traffic was heavy on all sections of the main Chamberlain Creek Road. The Cap Wallace Road, to the head of the North Fork of Elk Creek, was moderately to heavily used throughout the season until 5 September. Elk did not appear to avoid open roads during the calving and summer seasons (Table 32). Traffic was generally light on roads located in areas used by elk during these seasons, so it is not remarkable that roads were not avoided. An apparent avoidence of open roads was noted during the rutting and hunting seasons. Use was significantly lower than availability in areas less than 550 yards $(500 \mathrm{~m})$ and 950 yards $(870 \mathrm{~m})$ from open roads during these seasons, respectively. In addition, respective use for these seasons of areas greater than 1,350 yards $(1,230 \mathrm{~m})$ from roads was $70 \%$ and $90 \%$, both significantly exceeding availability. This phenomenon may be partially explained by the decreased availability of open roads effected by the general road closure after 1 September. Approximately $90 \%$ of the roads open after 1 September were moderately to very heavily (more than 9 vehicle trips/day) traveled, and were generally located along the periphery of the study area. During the rutting season, elk did not avoid roads with moderate traffic; however, areas within 550 yards $(500 \mathrm{~m})$ of roads with similar traffic were avoided during the hunting season. Elk significantly preferred areas greater than 1,350 yards $(1,230 \mathrm{~m})$ from heavily traveled roads during both seasons. Areas within 150 yards $(140 \mathrm{~m})$ of roads closed after 1 September were used significantly less than availabilfty during these seasons. Use of areas beyond this distance, approximated availability. 
Table 32. Percentages of availability and elk use related to distance to open roads, 1979.

\begin{tabular}{|c|c|c|c|c|c|c|c|}
\hline \multirow{2}{*}{$\begin{array}{l}\text { Distance to } \\
\text { Open Roads in } \\
\text { yards (meters) }\end{array}$} & \multicolumn{2}{|c|}{ Calving } & \multirow{2}{*}{$\begin{array}{c}\text { Summer } \\
\text { Use } \\
164\end{array}$} & \multicolumn{2}{|c|}{ Rut } & \multicolumn{2}{|c|}{ Hunt } \\
\hline & $\begin{array}{c}\text { Avail. } \\
300\end{array}$ & $\begin{array}{l}\text { Use } \\
43\end{array}$ & & $\begin{array}{c}\text { Avail. } \\
300 \\
\end{array}$ & $\begin{array}{l}\text { Use } \\
91\end{array}$ & $\begin{array}{c}\text { Avail. } \\
300\end{array}$ & $\begin{array}{l}\text { Use } \\
63 \\
\end{array}$ \\
\hline $0-150(0-140)$ & 30.7 & 34.9 & 32.3 & 10.7 & -3.3 & 5.7 & --0.0 \\
\hline $150-550(140-500)$ & 39.3 & 48.8 & 32.3 & 24.3 & --3.3 & 12.7 & --1.6 \\
\hline $550-950(500-870)$ & 17.7 & 14.0 & 16.5 & 15.7 & 11.0 & 10.0 & 3.2 \\
\hline $950-1350(870-1230)$ & 9.0 & 2.3 & 17.7 & 14.0 & 12.1 & 9.3 & 3.2 \\
\hline$>1350(>1230)$ & 3.3 & --0.0 & 1.2 & 35.3 & ++70.3 & 62.3 & ++92.1 \\
\hline
\end{tabular}

It is clear from Table 33 that elk preferred unlogged areas over logged areas. Use of unlogged areas was significantly greater than availability during the summer, rutting and hunting season, and for the whole season. Calving season use was equal to that of summer, but was not significant. In general, use of pre-1970 cuts, which are almost entirely some type of partial cut, was equal to availability during the calving season, but decreased during each successive season. At the same time, use of unlogged areas correspondingly increased. A finer breakdown of use in logged areas, by the decade during which the area was cut, indicated that use of cuts made before 1949 was generally lower than availability, while later cuts were used about equal to or less than their occurrence. However, relatively high use of cuts completed from 1960 to 1969 was observed during the calving season: this is explained by a preference for clearcuts at that time, most of which were made in the 60 's. Use of unforested areas was not observed. This pattern of use may be explained by a seasonal preference for more mesic higher elevational ranges, which are unlogged, rather than an avoidance of logged areas, which are mainly at lower elevations.

Table 33. Percentages of availability and elk use related to logged areas, 1979.

\begin{tabular}{|c|c|c|c|c|c|c|}
\hline \multirow{2}{*}{$\begin{array}{l}\text { Time of } \\
\text { Logging }\end{array}$} & \multirow{2}{*}{$\begin{array}{c}\% \\
\text { Availability } \\
300\end{array}$} & \multicolumn{5}{|c|}{$\%$ Elk Use } \\
\hline & & $\begin{array}{c}\text { Calving } \\
43\end{array}$ & $\begin{array}{l}\text { Summer } \\
164\end{array}$ & $\begin{array}{r}\text { Rut } \\
91 \\
\end{array}$ & $\begin{array}{c}\text { Hunt } \\
63 \\
\end{array}$ & $\begin{array}{l}\text { Total } \\
361\end{array}$ \\
\hline $1970-1979$ & 11.7 & 9.3 & 14.6 & --3.3 & 4.8 & 9.4 \\
\hline $1960-1969$ & 8.7 & 23.3 & 9.1 & 4.4 & 3.2 & 8.6 \\
\hline $1950-1959$ & 6.0 & 9.3 & 3.7 & 9.9 & 3.2 & 5.8 \\
\hline Pre-1949 & 34.3 & -16.3 & 29.3 & 24.2 & --15.9 & -24.1 \\
\hline (Unlogged) & 29.7 & 41.9 & $+43.3+$ & ++58.2 & +73.0 & ++52.1 \\
\hline (Non-forested) & 9.7 & --0.0 & --0.0 & -0.0 & --0.0 & --0.0 \\
\hline
\end{tabular}




\section{Relative Hunter Use and Elk Harvest}

The study area is in Hunting District 292, and also largely within the Blackfoot Special Management Area (BSMA), where roads are closed to vehicular access from 1 September through 1 December. This area was open for either sex archery hunting for elk from 8 September through 14 October 1979. There was also a general hunting season for antlered males and for either sex by special permit only, from 21 October through 25 November. Either sex permits were increased from 50 in 1978 to 75 during 1979 , even though a substantial area in the western portion of H.D. 292 was closed to either sex hunting last season.

The total number of hunters checked at the Bonner check station during the 1979 general hunfing season was 4,879 (Hartkorn 1979), approximately the same number as was checked the year before. A harvest of 50 elk was recorded during 1979, 29 from the BSMA and 21 from nearby surrounding areas. Fifty elk were also taken in the area during 1978. Three elk were taken by archers in 1979. Thirty-one (62\%) of the elk harvested in 1979 were males (17 spikes and 14 branch-antlered), $14(28 \%)$ were females, and $5(10 \%)$ were calves. 
DISCUSSION

We have now collected four years of pellet count data on all transects within the core study area (CSA). Several conclusions which we reported previously (Scott 1978, and Marcum et al. 1979) are reinforced after including results derived from the 1979 data. Chamberlain Creek elk continue to make almost universal use of the avallable habitats in the CSA. No habitat component has been preferred throughout all years and seasons, but elk use has been consistently less than avallability on primary upper slopes and ridgetops, dense small diameter lodgepole pine stands (pole-sapling successional stage), and on areas which are greater than 450 yards $(410 \mathrm{~m})$ from water. Except for spring and fall 1978 elk use of steep slopes $\left(>30^{\circ}\right)$ has also been less than availability. To date, the primary factors which have influenced habitat use patterns by $e 1 \mathrm{k}$ in the CSA have been a combination of weather plus vegetative composition, structure, and phenology.

01d and very old (OVO) pellet groups recorded during the spring 1979 count were considered to represent elk use in the CSA during fall 1978. The ovo pellets were located primarily on gentle $\left(0-15^{\circ}\right)$ mid-slopes or secondary upper slopes and ridges, on westerly aspects, and at elevations of $5,700-6,200$ feet $(1,740-1,890 \mathrm{~m})$. Relative to summer 1978, fall 1978 elk use increased at lower elevations, and in more open old stands within Douglas-fir habitat types with bunchgrass understories.

During the drought spring of 1977 , elk preferred southern subunits in the CSA at higher elevations, gentle slopes, and young stands of medium to large lodgepole pine in subalpine fir habitat types with mesic understory species. Conversely, elk preferred northern subunits at lower elevations, moderate to steep slopes, and old stands of large Douglas-fir in Douglas-fir habitats with more xeric understory species during the relatively wet spring of 1978. Precipitation during 1979 was slightly less than normal, and intermediate to that during 1977 and 1978 . Similarly, the amount and patterns of habitat use by elk during spring 1979 were 1ntermediate to, but less selective than, those of the other 2 years. Although partially a result of differences in sample size, spring elk use was significantly different from availability for only 10 environmental components during 1979, as compared to 16 during 1977 and 26 during 1978. However, spring 1979 use tended to exceed availability in both the more open stands of large Douglas-fir with pinegrass and heartleafed arnica dominated understories, and in the more dense and younger stands of subalpine fir and Engelmann spruce in subalpine fir habitat types with more mesic understory species. During all 3 springs, elk preferred clearings or open stands (canopy cover $0-25 \%$ ) with sight distances greater than 100 yards $(90 \mathrm{~m})$, but to a much greater extent in 1977 and 1978 than in 1979. In general, these results demonstrate the ability of $e 1 \mathrm{k}$ to adjust their yearly patterns of habitat selection and use to yearly variations of environmental conditions. 
As during previous years, elk use in summer shifts to more mesic habitats at higher elevations. The pellet count results for summer 1979 are similar to those for the summers of 1976 and 1978 , in that there was a high degree of uniformity in habitat selection by elk in the CSA. Elk use differed significantly from availability for only 10 habitat attributes during the summers of 1978 and 1979, and for 12 during 1976. There were 46 significant differences recorded for summer 1977 . As reported previously (Marcum et al. 1979), the patterns of relative habitat category use by elk in the CSA are similar for all summers; especially for elevation, aspect, topography and distance to water. The major yearly differences in summer elk use have been the very heavy selection of the more mesic vegetative sites and the great increase in total elk use of the CSA during the drought year of 1977 , as compared to the wetter years of 1976 and 1978. As noted previously, precipitation for 1979 was slightly less than normal, and intermediate to that for 1977 and 1978. As expected, total elk use of the CSA during summer 1979 was intermediate to the total use recorded during the summers of 1977 and 1978. However, summer habitat selection by elk during 1979 was more similar to that of the wetter years of 1976 and 1978 , than it was to the drought year of 1977. Last year we proposed that logging activities on high elevation, mesic summer ranges during dry years, when elk are concentrated in these habitats, might be more disturbing to elk than logging during wet years, when elk are likely to be more widely distributed. The 1979 results support this conclusion, but they indicate that the effects would be relatively much greater during a very dry year than during a moderately dry year.

During fall 1978, and spring and summer 1979, human disturbance associated with road construction in the CSA was light and intermittent, and was confined primarily to the northern end of the area. Elk avoided areas within 150 yards $(140 \mathrm{~m})$ of the new roads during a11 three seasons. Because this disturbance was intermittent, whereas elk use recorded by accumulations of pellet groups is relatively constant, the immediate displacement of elk by this kind of disturbance could have been much greater than the data indicate. Activities associated with logging will increase considerably next year, so results derived from pellet counts concerning the response of elk to human activities should be more definitive. As in previous years, apparent avoidance by elk of old roads and logged areas during 1979 can be attributed to other factors of habitat selection, and no distinct patterns of elk distribution with respect to planned roads or cutting units were noted.

Last year, we presented results showing a very high correlation between precipitation and elk use in the CSA (Marcum et a1. 1979). The correlation remains after including the 1979 data in the regression equation. This reinforces our conclusion that, when there is little human activity in the area, elk habitat use patterns in the CSA, and total use of the CSA are influenced primarily by direct and indirect influences of weather variations. The relationship shown between 
precipitation and $e l k$ use is perhaps the most important result of the study thus far. It aids us greatly in interpreting seasonal and yearly changes in the use of various habitat components by elk. Also, we know that total elk use of the CSA varies substantially during different years, even in the relative absence of human disturbance. Thus, it would be very difficult to assess the influence of planned logging activities on the levels of elk use in the CSA if we could not predict what the level of use would have been under undisturbed conditions.

Telemetry results for 1977,1978 , and 1979 point out the importance of the CSA to elk in the study area. The CSA encompasses the majority of the high elevation mesic areas in the study area. Total use was significantly greater than avallability for all three years ( $\leq \leq 0.01)$. The year-to-year trend in total use appears to be related to yearly differences in precipitation. Use was highest during 1977, an extremely dry year, and lowest during 1978, a moist year. E1k use during 1979 was intermediate to that of 1977 and 1.978, but was closer to that of 1977. Precipitation followed a similar pattern. A regression of CSA elk use and cumulative precipitation yielded a high negative correlation $(\mathrm{r}=-0.8)$. The percentage of yearly seasonal activity centers in the CSA showed a similar relationship, but a regression equation was not developed. Some seasonal variations in CSA elk use can be similarly explained in relation to precipitation. Summer use was significantly greater than availability for all three years. Use was greatest during 1977, decreased during 1978, and further decreased during 1979. If summer use were to follow the trend of total use in relation to precipitation, use during 1979 should be greater than during 1978 and approximate that of 1977. However, precipitation was only slightly below normal through May 1979, whereas during 1977 precipitation was we11 below normal for the same period. Consequent1y, sufficient moisture was available for spring plant growth and to delay dessication of vegetation at low elevations outside the CSA, thus providing elk with relatively more suitable foraging areas during 1979. The decreased use of the CSA during 1979 can further be attributed to a greater use by Lindberg-Potter elk of mesic, high elevation areas to the west of the CSA than of similar areas within the CSA. Use of the CSA during the rut was similar during 1977 and 1978, but was substantially higher during 1979. The fact that the fall of 1979 was unusually hot and dry accounts for this pattern of use. The trend of use during the 1979 hunting season was similar to that of the rut. This trend was probably the result of elk remaining in areas used during the rut, and hunter pressure forcing elk into areas which were least accessible and that had heavy cover. Most of these areas are in or adjacent to the CSA.

A breakdown of elk use by trap groups indicated that Grace's Landing elk consistently used the CSA more than the Lindbergh-Potter elk during al1 3 years. As in previous years, 1ittle overlap of home ranges occurred between these groups. A relatively greater amount of preferred summer range of the Grace's Landing elk, as opposed to the LindbergPotter elk, occurs in the CSA. The former group will therefore be most impacted by future logging activities in the CSA. 
Limited information is available on the movements of the 4 bul1 elk radio-collared in the study area. Most bulls were not located for an entire season due to various reasons. Two transmitters failed; 1 was broken off; 1 bull died; and 1 was not located af ter the summer of 1979. Bull elk No. 49, trapped at Grace's Landing, was successfully tracked during 1978 and for most of 1979. During 1978, as a 2-year-old, he was found during the calving and summer seasons east of the CSA, and during the rutting and hunting seasons in or near the CSA. During 1979, the initial spring locations for this animal were north of the CSA. He then moved east to the Pearson Creek drainage, next to the head of Wales Creek, and was last located south of the Chamberlain Burn in late August. Two bull elk, 4 and 5 years old, radio-collared at the Grace's Landing trap during the winter of 1977-78, generally used the study area little. They ranged widely to the east of the CSA, using the Pearson, Frasier, and Wales Creek drainages. The 4-year-old broke its collar off in late August, and the 5-year-old died of unknown causes in early July. A yearling bull was radio-collared at the Lindbergh Trap during the winter of 1978-79. Before its transmitter failed in early June, the bull was located in an area traditionally used by cow elk collared at the same trap. He was killed during the hunting season near Hungry Horse Reservoir, about 100 airline miles north of the study area. Hopefully, more bulls will be radio-tagged and successfully tracked in the future to provide more information concerning their movements and distribution.

Yearly average values for seasonal distribution and movement statistics were quite variable. Home range size, average distance moved between successive locations, and standard diameter during the 1979 calving season were intermediate between high values for 1977 and low values for 1978. During the summer seasons, values for these variables were highest in 1978, followed by 1979 and 1977 . The rutting season home range area was highest in 1977, decreased in 1978, and again decreased in 1979. Average distance moved between successive locations during the rutting season was nearly equal all 3 years. Rutting season standard diameters were highest in 1977, followed by 1979 and 1978. Hunting season home range area was greatest in 1979, intermediate in 1977, and lowest in 1978. Average distance moved between successive locations was likewise highest in 1979 , but lowest during 1977. The 1978 value equaled that of 1977. Hunting season standard diameters were lowest in 1977, and successively increased each year. For the entire season, yearly home range size and standard diameter decreased each successive year, whereas average distance moved stayed the same.

Yearly differences in seasonal home range areas and distance statistics for the calving and summer seasons appear to be related to yearly differences in precipitation, as was use of the CSA. During 1977, high elevations were snow-free and forage was available there early in the calving season, while during 1978 snow remained longer at upper elevations, so forage in higher areas was not available until later in the year. An intermediate situation occurred during 1979. 
Consequent1y, during 1978 elk were restricted to smaller areas with suitable forage than during 1977. They were similarly restricted during 1979, but to a lesser degree than in 1978. This was reflected by smaller home ranges and shorter movements during 1978. The opposite of this situation occurred during summers. During 1977, good forage was available only at higher, more mesic habitats which restricted the range of elk movements. Conversely, good forage was available at lower elevations later into the summer of 1978, allowing elk to utilize a larger area. During the summer of 1979 elk movements were intermediate between 1977 and 1979, as was precipitation.

Chamberlain elk used smaller areas than animals east of the Continental Divide in Montana. Over the past three years, Chamberlain elk used an area of about 70-100 $\mathrm{mi}^{2}\left(182-260 \mathrm{~km}^{2}\right)$ during the calving through hunting seasons. This also included most of the area used during the winter. Year-long home ranges for 30 radio-equipped elk at the Long Tom study area covered $675 \mathrm{mi}^{2}\left(1,755 \mathrm{~km}^{2}\right)$ (Lonner 1979). Cada (1978) reported year-long home ranges of $143 \mathrm{mi}^{2}\left(370 \mathrm{~km}^{2}\right)$ and $568 \mathrm{mi}^{2}\left(1,471 \mathrm{~km}^{2}\right)$ for 3 elk from the Gallatin Valley and for $9 \mathrm{elk}$ from the Madison Valley, respectively. Seasonal averages of home range areas, average distance moved between location, and standard diameters for Lonner's elk were higher than those for Chamberlain elk during all seasons. Lonner also reported large yearly differences in seasonal movements and home ranges for individual elk. Also, elk reported on by Lonner and Cada generally tend to migrate much greater distances between summer and winter ranges than do Chamberlain elk. Yearly differences in movements and home range size between elk east and west of the Continental Divide may be related to migratory tradition, and the distances elk must travel between acceptable winter and summer ranges. Seasonal differences may be attributable to yearly variations in movements and home ranges, differences in habitat between areas, sample size, or perhaps a combination of these or other factors.

Telemetry results for 1977,1978 , and 1979 indicate that habitat utilization of radio-collared $\mathrm{elk}$ in the study area was variable. However, some patterns of use are evident for the May to December study periods. Elk primarily used 5,100-6,200 feet (1,530-1,860 m) elevations, significantly during 1978 and 1979. During 1977, elk preferred the $5,700-6,200$ feet $(1,740-1,890 \mathrm{~m})$ interval within this range. Low elevation areas, between 3,800 and 4,400 feet $(1,140-1,320 \mathrm{~m})$, were consistently used significantly less than availability. Use of different slope positions was variable, but upper and mid-slopes were used the most. Mid-slopes were significantly preferred in 1977, while during 1979 upper slopes of secondary ridges were significantly preferred. Ridgetops, primarily secondary ridgetops, were also used in excess of availability, significantly so during 1978 and 1979. Lower slopes were consistently used significantly less than their occurrence. There was no evident preference for drainage bottoms or drainage heads. Concave configurations were used greater than their occurrence, significantly so during 1977 and 1978. Use of other configurations (convex, straight, and undulating) was equal to, or slightly less than availability. 
There was generally no consistent preference shown by radio-collared elk for overstory canopy cover classes during the 3 years considered here. Most elk use was in moderate to dense stands; however, use of dense and closed stands increased during 1979 to significantly exceed availability. Pole-young, mixed tree species stands received the greatest use, but were generally used in proportion to their occurrence. Within this type, though, stands with dense canopy coverage were slightly preferred. Mature-old, mixed species stands were always used greater than their availability: stands with dense canopy cover were preferred, significantly so during 1978 and 1979. ABLA/XETE-VAGL and ABLA/LIBO habitat types received the greatest use relative to availability. ABLA/ CACA and PSME/CARU types were also preferred. The ABLA/MEFE habitat type was used the most, but not in excess of availability. PSME/VACA and PSME/SYAL habitat types were consistently used less than their occurrence. Little preference was shown for slope, aspect, and for areas near water or moist sites. With respect to slope and aspect, gentle slopes $\left(0-15^{\circ}\right)$ were slightly preferred during 1979, but flat areas (no aspect) were significantly underutilized. This incongruity is resolved by the fact that most of the use of gentle slopes was not on $0^{\circ}$ slopes or flats. Regarding use of moist areas, Marcum (1975) found that elk in the Sapphire Mountains significantly preferred areas within 50 yards $(46 \mathrm{~m})$ of water. However, water or moist sites are much more prevalent in the Chamberlain area, than in the Sapphire area. Productive areas near water are no doubt important to Chamberlain elk, as indicated by the relatively high use of the moist ABLA/CACA habitat type. But, the availability of such areas appears not to exert as great an influence on the distribution of Chamberlain elk, as it does in areas where molst sites are less avaflable.

Seasonal patterns of habitat utilization were more variable than total use patterns, but some trends are evident. During all calving seasons, 5,100-5,600 feet $(1,150-1,700 \mathrm{~m})$ elevations were significantly preferred. During 1978 , lower elevations $(4,500-5,000 \mathrm{ft} ; 1,370-1,520 \mathrm{~m})$ were also prominently used; while during 1979, these same low elevations plus higher elevations $(5,700-6,200 \mathrm{ft} ; 1,740-1,890 \mathrm{~m})$ were heavily used. E1k used upper and mid-slopes, primarily upper slopes of secondary ridges, the most, generally in excess of availability. Secondary ridgetops were also favored in 1979. Little selectivity for aspect was observed during calving seasons: north, northeast, west and northwest aspects were mainly used. With regard to canopy coverage, use was quite variable. Moderate cover was preferred during 1977; 1ight cover was significantly favored during 1978; and dense cover was used the most during 1979. Pole-young, mixed tree species stands were used the most. Light canopy coverage in this type was generally favored, whereas moderate and dense canopy areas were used less than, and equal to their occurrence, respectively. Mature-old, mixed tree species stands were always preferred, especially stands with dense canopy. Use of clearcuts, which account for only $2.7 \%$ of the study area, was variable: no use was observed in 1977 , but $7.5 \%$ and $14.0 \%$ use was recorded for 1978 and 1979 , respectively. PSME/CARU and ABLA/LIBO were the preferred habitat types during the calving seasons. 
E1k were found at a broader range of elevations during summers. The greatest use occurred in areas of 4,500-6,200 feet $(1,370-1,890 \mathrm{~m})$ elevation. A significant preference for 5,700-6,200 feet $(1,740-1,890 \mathrm{~m})$ elevations was noted for a11 years. Lower elevations $(5,100-5,600 \mathrm{ft}$; $1,550-1,700 \mathrm{~m})$ were significantly preferred during 1978 and 1979; and high use of the 4,500-5,000 feet $(1,370-1,520 \mathrm{~m})$ interval also occurred. Upper and mid-slope positions were generally favored. During 1977, a dry year, drainage heads were notably used. Concave slope configurations were favored every summer. Timber stands with dense to closed canopy were used the most, but, except during 1978, not in excess of availability. During summer 1977, use of clearcuts significantly exceeded availability. Pole-young, mixed tree species stands, primarily with a dense canopy received the greatest use; and dense, mature-old, mixed species stands were used greater than their occurrence. Elk were found to use several habitat types. The ABLA/XETE-VAGL, ABLA/LIBO, ABLA/CACA and PSME/CARU types were generally favored. The greatest amount of use was in the ABLA/MEFE type, but use was less than the availability of this plant community.

During the rutting seasons, elk use with respect to elevation was quite inconsistent. Moderately low elevations $(4,500-5,000 \mathrm{ft} ; 1,370-$ $1,520 \mathrm{~m})$ were used most during 1977, even lower elevations $(3,800-4,400$ $\mathrm{ft} ; 1,140-1,320 \mathrm{~m})$ were used during 1978 , and higher elevations $(5,100$ $6,200 \mathrm{ft} ; 1,550-1,890 \mathrm{~m})$ were chief1y used during 1979. Little consistent preference for slope position was noted during the rutting season. Mid-slopes were preferred during 1977; ridgetops, upper and mid-slopes were all used about equal to availability during 1978; and secondary upper slopes were favored during 1979. Concave slope configurations were preferred, significantly during 1977 and 1979. Dense and closed canopy areas were favored during 1979 , otherwise no preference was generally noted. Use of pole-young mixed stands remained high, and mature-old mixed stands continued to be preferred. Use of habitat types was similar to that of summer.

During the hunting seasons, elk generally preferred 5,100-6,200 feet $(1,550-1,890 \mathrm{~m})$ elevations. In addition, elk used elevations as low as 4,500 feet $(1,370 \mathrm{~m})$ during 1977 . However, higher elevations, up to 6,800 feet $(2,070 \mathrm{~m})$, were used during 1979. Primary upper slopes and mid-slope positions were favored. Ridgetops were used in excess of availability during all years. No consistent pattern of use was noted for slope configuration. With respect to canopy cover and successional stage, use during hunting season resembled that of the rut. ABLA/XETEVAGL, ABLA/LIBO, and ABLA/MEFE habitat types were preferred.

Elk appeared to avoid areas within 0.5 mile $(0.8 \mathrm{~km})$ of active human disturbance during 1978 and 1979, except during summer 1979 when areas within $1.0 \mathrm{mile}(1.6 \mathrm{~km})$ were avoided. Use was also significant1y greater than avallability for areas greater than $1.5 \mathrm{mile}(2.4 \mathrm{~km})$ and 2.0 miles $(3.2 \mathrm{~km})$ from disturbance during the summers of 1978 and 1979 , respectively. During the 1979 rutting season, use significantly exceeded 
the availability of areas greater than 2.0 miles $(3.2 \mathrm{~km})$ from disturbance. However, disturbance was genera1ly light during these years, especially during the calving seasons. Also, pellet-group counts and telemetry results indicated that elk use near areas of disturbance would probably have been low, even in the absence of this disturbance. Furthermore, analysis of radio-collared elk use in areas near new roads in the CSA for 1978 and 1979 indicated no avoidance of the new roads. However, these roads, at present, occur in only a small portion of the area available to radio-collared elk. Elk reaction to human disturbance will become more clear in future years when more extensive road building and logging occurs in areas of traditionally high elk use.

Elk reaction to open roads was simflar for all three years. Elk did not avoid open roads during the calving and summer season. However, during the rutting and hunting seasons, areas within 550 yards $(500 \mathrm{~m})$ were significant $1 \mathrm{y}$ avoided. In addition, there was a significant preference for areas greater than 1,350 yards $(1,230 \mathrm{~m})$ from open roads during the latter 2 seasons. This difference may be partially explained by the decreased availability of open roads effected by the general road closure after 1. September. However, roads open after 1 September were heavily traveled, and elk avoided areas within 550 yards $(500 \mathrm{~m})$ of these roads during the rut. An even greater negative response to open roads was noted during hunting seasons. For all years, areas within 550 yards $(550 \mathrm{~m})$ of roads closed after 1 September were used less than their occurrence, significantly so during the 1979 rutting season, and during the 1978 and 1979 hunting seasons. During the 1977 and 1978 hunting seasons use was less than that for the rutting season; but, the reverse situation occurred during 1979. This apparent avoidance of closed roads may be a result of elk habitat preference for areas away from these roads, or a response to hunters walking roads during the hunting season.

E1k use of logged areas followed a fairly consistent pattern. Areas cut after 1970 were generally used equal to their occurrence, but use was notably high during the 1977 and 1978 rutting seasons. Lands logged before 1970 were used about equal to their availability during the calving seasons, and use generally decreased during subsequent seasons. Elk use of uncut areas correspondingly increased. This pattern of use is probably a result of elk preferring mesic, moderate to high elevation areas that happen to be unlogged, rather than an avoidance of logged areas. Most logged areas are located at lower elevations.

The road closures initiated in the BSMA during 1974 have contributed to increased hunting opportunity and quality in recent years. In particular, the opportunities for either sex elk hunting tend to be increasing here, while they tend to be decreasing in many areas where roads remain open to vehicular access. 


\section{REFERENCES CITED}

Cada, J. D. 1978. Gallatin big game studies. Mont. Dept. Fish and Game, Helena, Mont. Proj. No. W-130-R-8, Job No. I-3.1. 64 pp.

Harrison, J. L. 1958. Range of movement of some Malayan rats. J. Mamma1. 38(3):190-206.

Hartkorn, F. 1979. Personal communications concerning hunters and elk harvest through the Bonner check station.

Lonner, T. N. 1976. Job II-B, Long Tom Creek Study. Pages 15-56 in Ann. Prog. Rpt. of Mont. Coop. Elk-Logging Study.

Lonner, T. N. 1979. Job II-B, Long Tom Creek Study. Pages 5-37 in Ann. Prog. Rpt. of Mont. Coop. Elk-Logging Study.

Lyon, L. J. 1973a. Job II-A, Proc. B-1, Conduct annual pellet count surveys to describe elk distribution patterns within the Burdette Creek-Deer Creek area. Pages 26-45 in Ann. Prog. Rpt. of Mont. Coop. Elk-Logging Study.

Lyon, L. J. 1973b. Job II-A, Proc. A-1, Burdette Creek-Deer Creek vegetation analysis. Pages $7-25$ in Ann. Prog. Rpt. of Mont. Coop. Elk-Logging Study.

Marcum, C. L. 1975. Summer-fall habitat selection and use by a western Montana elk herd. Ph.D. dissertation, Univ. of Mont., Missoula. $188 \mathrm{pp}$.

Marcum, C. L., M. D. Scott, and J. Lehmkuh1. 1978. Job II-D, Chamberlain Creek Study. Pages 55-113 in Ann. Prog. Rpt. of Mont. Coop. Elk-Logging Study.

Marcum, C. L, J. F. Lehmkuh1, and M. D. Scott. 1979. Job II-D, Chamberlain Creek Study. Pages 38-108 in Ann. Prog. Rpt. of Mont. Coop. Elk-Logging Study.

Nie, N. H., C. H. Hull, J. G. Jenkens, K. Steinbrenner, and D. H. Bent. 1975. SPSS:Statistical package for the social sciences. Second edition. McGraw-Hill, Inc., New York. 675 pp.

Pfister, R. D., B. L. Kovalchik, S. F. Arno, and R. C. Presby. 1977. Forest habitat types of Montana. Intermountain For. and Rge. Expt. Sta. and U.S.D.A. Forest Service. Gen. Tech. Rpt. INT-34. May 1977. 174 pp.

Scott, M. D: 1978. E1k habitat selection and use on an undisturbed summer range in western Montana. M.S. Thesis. Univ. of Mont., Missoula. $98 \mathrm{pp}$. 
Snedecor, G. W., and W. G. Cochran. 1967. Statistical methods:sixth edition. The Iowa St. Univ. Press, Ames. 593 pp.

Steele, R. W. 1980. Weather data summary 1957 through 1979, Lubrecht Experimental Forest, Greenough, Montana. Mont. For. and Cons. Expt. Sta. Misc. Paper No. 13. School of Forestry, Univ. of Montana, Missoula. 


\section{BUREAU OF LAND MANAGEMENT Library Deriver Service Center}

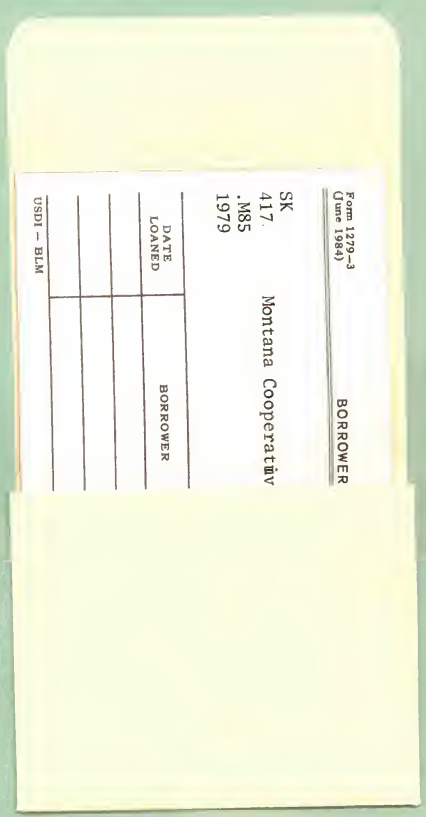

